\title{
Report of the
}

\section{Thirty-Seventh National Conference on}

\section{Weights and Measures}

\section{2}

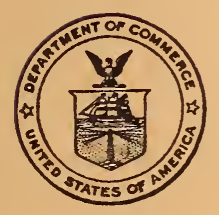

U. S. Department of Commerce

National Bureau of Standards

Miscellaneous Publication 206 


\section{SELECTED WEIGHTS AND MEASURES PUBLICATIONS OF THE NATIONAL BUREAU OF STANDARDS}

\section{NBS Handbook 26 Weights and Measures Administration}

Discussing the broad subject of weights and measures supervision, this handbc gives particular attention to the general aspects of weights and measures admir tration, mechanical activities of officials, and systems of records. [Appendi: include recommendations for standards and equipment for State and 10 regulatory agencies.] 292 pages. Price $\$ 1.50$.

\section{NBS Handbook 37 Testing of Weighing Equipment}

As a manual for State and local weights and measures officials, this handbo describes various types of commercial weighing equipment, principles of th operation, and methods for their inspection and testing. 184 pages. $\operatorname{Pr}$ $\$ 1.25$.

NBS Handbook 44 Specifications, Tolerances, and Regulatio: for Commercial Weighing and Measuris Devices

This Handbook deals with specifications, tolerances, and regulations for cos mercial weighing and measuring devices, as adopted by the National Conferen on Weights and Measures and recommended by the National Bureau of Standar for State promulgation. [To keep the material up to date, the NBS regular issues correction sheets, which are available without cost upon application to $t]$ NBS.] 144 pages. Price $\$ 1.25$.

\section{NBS Handbook 45 Testing of Measuring Equipment}

A companion volume to Handbook 37, this handbook presents information co: cerning commercial measures and measuring devices and their inspection ar testing. Specific outlines supplement the discussions on testing procedure 205 pages. Price $\$ 1.25$.

NBS Circular 501

Federal and State Weights and Measure Laws

This publication is a completely indexed compilation of all Federal and Stal weights and measures laws, through 1949 enactments. [Supplements will $\mathrm{k}$ issued periodically, as indicated by subsequent enactments. A pocket is provide inside the back cover for such supplements.] 1,182 pages. Price $\$ 5.75$.

NBS Misc. Pub. 203 Index to the Reports of the Nationa Conference on Weights and Measures From the First to the Thirty-sixth, 190. To 1951

The large amount of information on a wide variety of weights and measure subjects, which is embraced within the published reports of the National Confer ence, is made more valuable by reason of the means provided for locating all mate rial on a specific subject and all material presented by any particular speaker. 4 pages. Price $20 \phi$.

Order all publications, with remittance, from the Superintendent of Docu. ments, Government Printing Office, Washington 25, D. C. 



\section{Report of the}

\section{hirty-Seventh National Conference on}

\section{Weights and Measures}

Attended by Representatives from Various States

Sponsored by the National Bureau of Standards Washington, D. C., May 20, 21, 22, and 23, 1952

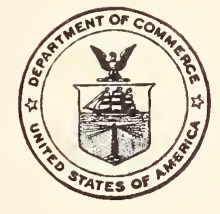

ational Bureau of Standards Miscellaneous Publication 206 Issued March 19, 1953 



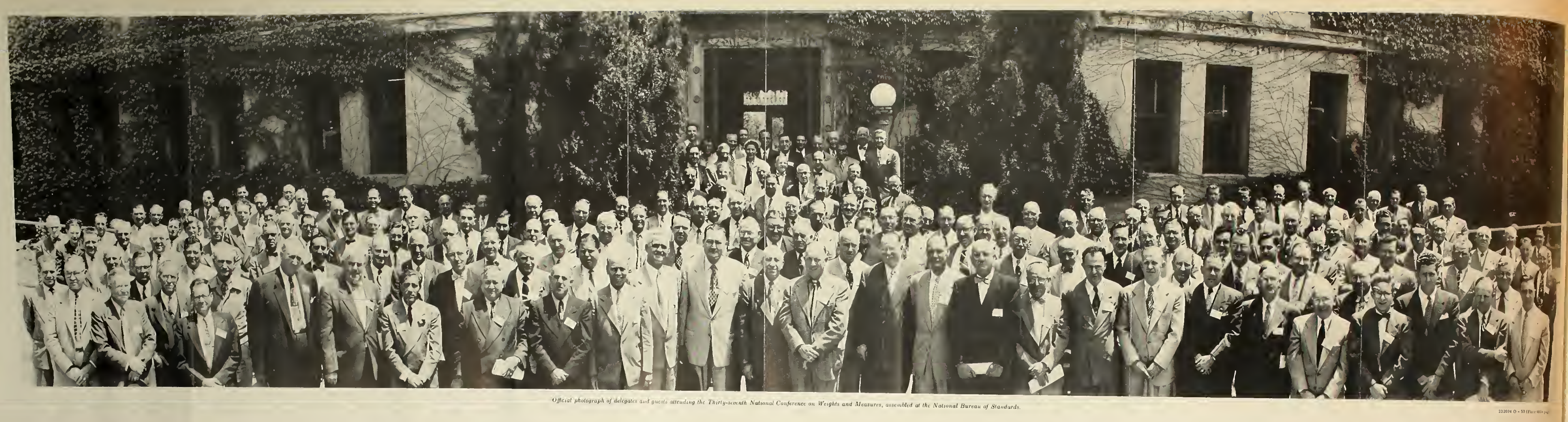





\section{GONTENTS}

FIRST SESSION-MORNING OF TUESDAY, MAY 20, 1952

cation, by R. W. Searles, Deputy County Sealer, Medina, Ohio ome to Washington, by Hon. F. Joseph Donohue, President, Board of mmissioners, District of Columbia.

corial Service for Departed Members, by R. W. Searles, Deputy ('ounty aler, Medina, Ohio

ort of the Secretary of the Conference, by W. S. Bussey ress by Dr. A. V. Astin, Director, National Bureau of Standards

Men Who Make the Conference, by W. E. Sheehy, County Sealer of eights and Measures, Bridgeport, Conn.

Call of States

SECOND SESSION-AFTERNOON OF TUESDAY, MAY 20, 1952

Call of State and Regional Associations

atoes in Retail Cartons, by C. A. Lyon, Director, Division of Markets d Standards, State of New Hampshire

$r$ IVeights, by G. F. Austin, Jr., Deputy Sealer of Weights and Measures, troit, Michigan

ld Word "Net" be Mandat ory in Quantity Statements, by J. F. Blickley, irector, Bureau of Standard Weights and Measures, Commonwealth of mnsylvania dardization of Food Packages, by I. M. Levy, Sealer of Weights and easures, Chicago, Illinois

THIRD SESSION-MORNING OF WEDNESDAY, MAY 21, 1952

ort of the Committee on Trading by Weight, Presented by J. Fred True,

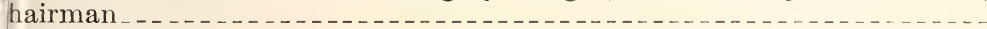
ress by Dr. E. C. Crittenden, Consultant to the Office of the Director, ational Bureau of Standards

n Holding Tanks, by H. J. McDade, Sealer of Weights and Measures, an Diego, California

Measurement of Petroleum, by E. L. Hoffman, Socony-Vacuum Oil Co. ew York, N. Y.

in Weighing, by David Lundeen, State Weighmaster, Track and Hopper cale Department, State of Minnesota, President National Scale Men's

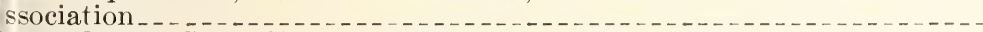
Iway Track Scale Testing Program, by J. N. Todd, Superintendent, cales and Work Equipment, Southern Railway System, Washington, D. C.

\section{FOURTH SESSION-MORNING OF THURSDAY, MAY 22, 1952}

ort of Committee on Education, Presented by Charles Morris Fuller,

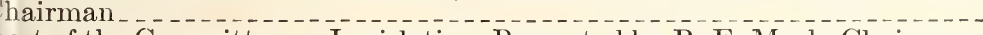
ort of the Committee on Legislation, Presented by R. E. Meek, Chairman Work in the Field, by Alfred Di Piero, Superintendent of Weights and leasures, Camden, N. J.

Lake City and Ice Cream, by E. C. Westwood, Sealer, Department of Teights and Measures, Salt Lake City, Utah

-Weight Markings of Packages and Cans of Tobacco, by G. H. Leithauser, enior Assistant Superintendent of Weights and Measures, Baltimore, Iaryland.

of Peat Moss, by T. A. Carter, Supervisor, Division of Standards, State f Washington_ jing Cloths, by J. E. Brenton, Chief, Bureau of Weights and Measures, tate of California 
Report of the Committee on Methods of Sale of Commodities, Presented J. G. Rogers, Chairman .....

Training Schools for Weights and Neasures Officials and Servicemen. II. M. Hoxie, Service Manager, Bennett Pump Division, John Wic Company, Muskegon, Mich

Report of Conference Committee on Nominations, and Election of Cffice Presented by J. E. Brenton, Chairman

Belt Conveyor Scales, by R. O. Bradley, Toledo Scale Company, Tolec Ohio.

Testing of Vehicle Tank Meters, by W. A. Kerlin, County Sealer of Weigh and Measures, Oakland, Calif.

\section{SIXTH SESSION-MORNING OF FRIDAY, MAY 23, 1952}

Dr. A. V. Astin Presented

Appointment of Standing Committees

Report of Committee on Methods of Sale of Commodities (continued), Pl sented by J. G. Rogers, Chairman

Report of the Committee on Specifications and Tolerances, Presented by P. McBride, Chairman

Remarks of Arthur Sanders.

Report of the Conference Committee on Resolutions, Presented by M. Nelson, Chairman

Report of the National Conference Treasurer, George F. Austin, Jr Ralph IV. Smith Made Honorary Life Member

Neeting of the Executive Committee

Persons attending Conference. 


\section{OFFICERS AND COMMITTEES}

\section{OFFICERS}

(Present and serving during the Thirty-seventh National Conference)

l'residents :

d. R. Fisher, State Sealer of Weights and Measures, Department of Labor, Providence, R. I.

irling Hansen, Supervisor, State Department of Weights and Measures, Minneapolis, Minn.

R. D. Thompson, State Supervisor of Weights and Measures, Division of Markets, Department of Agriculture and Immigration, Richmond, Va.

J. F. True, State Sealer of Weights and Measures, Board of Agriculture, Topeka, Kans.

G. H. Lerthauser, Senior Assistant Superintendent of Weights and Meastures City of Baltimore, Id.

etary: W. S. Bussey, Chief, Office of Weights and Measures, National treau of Standards, Washington, D. C.

surer: G. F. Austrn, Jr., Deputy Sealer of Weights and Measures, Detroit, ich.

\section{EXECUTIVE COMMITTEE}

(As elected by the Thirty-seventh National Conference)

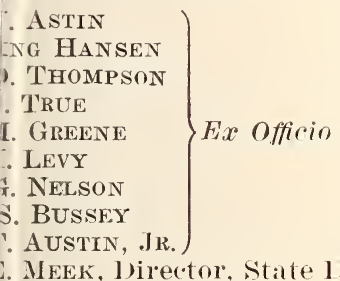

MEEk, loirector, State loivision of Weights and Measures, Indianapolis, Ind. PeIkert, City sealer of Weights and Measures, Sheboygan, Wis.

w. O'Nerl, City Sealer of Weights and Measures, Cambridge, Mass.

I. Stender, Assistant Commissioner, State Department of Agriculture, Columia, S. C.

G. Rrce, State Inspector, Bureau of Weights and Measures, White Plains, N. Y.

E. CRAWFoRd, City Inspector of Weights and Measures, Jacksonville, Fla.

C. Westwood, City Sealer of Weights and Measures, Salt Lake City, Utah. A. Boyle, Deputy State Sealer, Bureau of Weights and Measures, Augusta, Iaine.

1. MaHonex, State Superintendent of Weights and Measures, College Park, Id.

W. Searles, Deputy County Sealer of Weight and Measures, Medina, Ohio. M. Fuller, County Sealer of Weights and Measures, Los Angeles, cillif. O. Samenfink, City Sealer of Weights and Measures, Rochester, N. X.

H. Isrng, Superintendent of Weights and Measures, City of Louisville, Ky.

M. Boucher, Supervisor, Iepartment of IVeights, Measures, and Markets, Vashington, D. C.

P. DAGGETT, County Inspector of Weights and Measures, North Girard, Pa.

\section{STANDING COMMITTEES}

As constituted at the conclusion of the Thirty-seventh National Conference, : personnel and organization of each of the standing committees of the Conence are as reported below. As reported, the membership of each committee lects the appointments made by the President of the Conference, changes which ve occurred from expiration of term or other cause, and the elections by the eral committees of chairmen, and in one case secretary, for the ensuing year. e term of office for each committee member, in years, is shown by the figure parentheses following each entry.) 


\section{COMMITTEE ON SPECIFICATIONS ANI) TOLERANCES}

J. l'. Mclinue, State Director of Standards and Necessaries of Life, Boston, Chairman. (1)

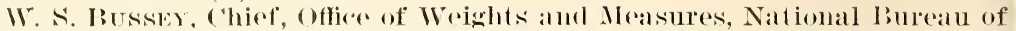
arols, Washington, I). C., Secretary. (3)

R. E. MEEk, Director, State Dirision of Weights and Measures, Indiau Ind. (5)

Robert Whrmays, County Sealer of Weights and Measures, Mineo'a, N. Y I. W. Writ, City Sealer of Weights and Measures, Milwaukee, IVis. (2)

\section{COMMITTEE ON METHODS OF SALE OF COMMODITIES}

J. G. Rogers, State Superintendent of Weights and Measures, Trenton, Chairman. (3)

C. D. Butcom, State Superintendent, Weights and Measures Division, R: N. C. (2)

J. E. Brenton, Chief, State Bureau of Weights and Measures, Sacramento, (4)

G. H. Leitrauser, Senior Assistant Superintendent of Weights and Mea ('ity of Baltimore, Mr. (5)

I. M. Lwy, ('ity sealer of Weights and Measures, Chicago, Ill.

\section{COMMITTEE ON LEGISLATION}

M. A. Nefson, Chief, State Bureau of Marketing and Enforcement, La Mich., Chairman. (5)

C. A. BAKER, Director, State Bureau of Weights and Measures, Albany, (1)

Ii. M. BoDENwEIser, County Superintendent of Weights and Measures, Tre N. J. (4)

V. D. Campbert, Deputy State Sealer, Columbus, Ohio.

I). M. 'TURnbuld, Supervisor, Dirision of Licenses and Standards, CirgR Seattle, Wash. (3)

\section{COMMITTEE ON WEIGHTS AND MEASURES EDUCATION}

C. M. Fuluk, County Sealer of Weights and Measures, Los Angeles, Calif., C. man. (3)

J. F'. Blicklex, Director, State Bureau of Standard Weights and Measures, risburg, Pa.

G. E. Carpenter, Supervisor, State Dirision of Weights and Measures, Mo lier, Vt. (2)

H. E. CrAwford, City Inspector of Weights and Measures, Jacksonville, Fla.

J. T. Kennedy, Director, Department of Weights, Measures, and Markets, $Y$ ington, D. C.

(1)

\section{COMMITTEE ON TRADING BY WEIGHT}

J. F. True, State Sealer, Weights and Measures Division, Topeka, Kans., C man. (2)

J. J. LevitT, State Superintendent of Standards, Springfield, Ill.

A. J. MAYER, State Division of Veights and Measures, Baton Rouge, La.

J. II. MLEK, Director, State Division of Markets, Richmond, Va. (1)

J. W. Rerse, Supervisor, State Division of Weights and Measures, Des Mol Iowa. (4)

\section{COMMITTEES AC'TING ONLY DURING THE THIRTY-SEVENTH NATIONAL CONFERENCE}

('ommittee on Nominations: J. E. Brenton of California, Chairman; C. A. B. of New York, J. F. BLICkLey of Pennsylvania, J. Roy Jones of South Caro J. J. LEVITT of Illinois, C. C. MoraAN of Gary, Indiana, R. J. ZIERTON, of Rar Wisconsin.

Committee on Resolutions: M. A. NeLson of Michigan, Chairman, A. C. BEe of Camden, New Jersey, W. L. Daniers of Seattle, Washington, J. E. MAнr of Maryland, M. G. Rick of New York, Louss Snow of Bridgeport, Connect Ladies' Committee: Mrs. C. M. Fuller, Chairman, Mrs. J. M. Dietz, Mrs. H MeeK, Mrs. J. 'T. Kennedy, Mrs. W. Ś. Bussey, Mrs. M. W. Jensen.

In Charge of Registrations: Mrs. F. C. Bell, Mrs. K. M. Schwarz.

In Chave of Badyes: H. L. BADGER. 


\title{
ORT OF THE THIRTY-SEVENTH NATIONAL INFERENGE ON WEIGHTS AND MEASURES
}

\author{
SORED BY THE NATIONAL BUREAU OF STANDARDS, AND HELD \\ HE WARDMAN PARK HOTEL, WASHINGTON, D. C., MAY 20, 21, 22, \\ 23,1952
}

\section{T SESSION-MORNING OF TUESDAY, MAY 20, 1952}

(R. D. Thompson, Vice President, presiding)

invocation was delivered by the Conference Chaplain, R. W. es, Deputy County Sealer of Weights and Measures, Medina y, Ohio. Following the invocation, the Honorable F. Joseph nue, President, Board of Commissioners, District of Columbia. led to the delegates a welcome to the City of Washington. Mr. es conducted an appropriate memorial service for departed iers.

\section{RT OF THE SEGRETARY OF THE CONFERENGE, W. S. BUSSEY}

Secretary of the Conference, I present officially the resignation . Edward U. Condon from the office of President of the National zrence on Weights and Measures, effective as of the date of his hation as Director of the National Bureau of Standards, Septem), 1951. Dr. Condon's letter of resignation follows:

al Conference on Weights and Measures

S. Bussey, Secretary

ial Bureau of Standards

ngton 25, D. C.

ucident with my resignation as Director of the National Bureau of Standeffectire on the thirtieth day of September, I consider it proper for me to as President of the National Conference on Weights and Measures, and tender my resignation to you for transmittal at the proper time to the rence.

work of the Conference is of great importance to the successful operations imerce and industry throughout the Nation. I know that the Conference ntinue its successful endeavors in this field in the years to come and that endearors will be marked by the same spirit of cooperation which has resent in the years of my association with the Conference.

with considerable regret, therefore, that I now sever my official connecith the State and local weight and measures officials in the United States. 1 continue to be interested in the advances which such officials are making zhout the Nation in the field of weights and measures. erely,

\section{(Signed) E. U. Coxpon, Director.}

National Conference on Weights and Measures has continued inction effectively throughout the year, especially through the al standing committees.

e nature of the National Conference is such that its interim ities must be carried on by the committees and officers. The full ration of each committee member and the cooperation of all mem- 
ber's of the Conference with the committees are essential to prog Since practically all Conference business must be conducted by $n$ you can help immeasurably if you will reply to all correspond promptly.

The Conference is the "hub of the wheel" of uniform and prog sive weights and measures administration in the United States. is our duty to keep it well oiled with our enthusiastic cooperation support in order that this wheel may keep rolling at the hig possible rate of speed and efficiency.

This is your Conference. It was established for the benefit o1 of the people of the United States. The true value of the Con ence will be determined by the contributions that each of us, as i viduals, make to its various activities.

(Mr. Bussey continued his report by describing the procedures that woul followed in the conduct of the Conference. The method of distribution of pa and reports during the Conference was explained. The report ended wi description of the social functions that had been arranged.)

\section{ADDRESS BY DR. A. V. ASTIN, DIREGTOR, NATIONAL BUREAU STANDARDS}

(Dr. A. V. Astin addressed the Conference concerning the part the Nati Bureau of Standards is playing in the national defense program and told of these responsibilities had increased tremendously during the past few years. concluded his remarks with the following summary of the derelopment weights and measures throughout the Nation during the past year.)

I would like to report on the part of the Bureau with which are most closely connected-its Office of Weights and Meast Under the able leadership of W. S. Bussey, we have attempter fulfill numerous requests for assistance and advice from the $m$ bers of this Conference. Our primary purpose in this area is in fillment of the basic activity authorized by the Congress to coope with the States to secure uniformity in weights and measures 1 and in methods of inspection.

Since the 36th National Conference, the staff of the Office of Weis and Measures has been increased by two members. The employn of M. W. Jensen as Assistant Chief of the Office was announced by Director last year, and $\mathrm{Mr}$. Jensen started work at the Bureau July 2, 1951.

We have also succeeded in procuring the services of C. H. Oak formerly Superintendent, Division of Weights and Measures, S of Wyoming. Mr. Oakley, who started his Federal employment January 7 of this year, underwent training at the National Bur of Standards Master Scale Depot at Clearing Illinois, at the Bur in Washington, and in the field.

The employment of Mr. Oakley makes possible the culminatior our plan to have in operation two railway track scale testing ur He has been assigned to one of our two units, and the other is be operated by D. V. Smith, who has been with the Bureau for m than 27 years. Between scheduled tests, both of these men are mak their time available to State and local weights and measures offici It is felt that efficient utilization of their time results in greater 1 formity and better application of recommended test procedures.

Improvement in the efficiency and coverage of weights and meast, enforcement throughout the Nation has continued during the 1 year. Many jurisdictions have purchased equipment for test 
sale meters. Additional large-capacity scale testing units have placed in service. Many States, counties, and cities have yed additional personnel.

some States, legislative improvements have been made, but no action has been culminated. We still have five States with no rehensive weights and measures control at the State level. There y one State, however, which has no weights and measures control level.

Office of Weights and Measures of the National Bureau of lards has had a representative present and participating in every al conference of weights and measures officials during the yearState and regional. We feel that through these meetings we are to keep in touch with activities, progress, and requirements of tate and local jurisdictions.

iff members of the Office of Weights and Measures have made mber of official visitations to State and local offices, and have ivored to furnish counsel, information, and advice whenever it een requested.

ree publications of importance to all weights and measures ls and to allied industries have been issued by the Bureau since 6th National Conference. NBS Handbook 45, Testing of Meas: Equipment, the fourth and final of the series of handbooks for guidance, became available about August 1, 1951. This book $\mathrm{d}$ be, and we sincerely hope soon will be, read and used by all e weights and measures officials and related experts in business ndustry.

e Report of the 36th National Conference became available about niddle of January 1952 as NBS Miscellaneous Publication 202. f you who registered at the 36 th Conference have been sent copies is report.

tional Bureau of Standards Circular 501, Federal and State hts and Measures Laws, was issued during March of this year. is been appraised as a most valuable edition for all weights and ures offices, manufacturers of weighing and measuring equipment, producers and processors of commodities. This compilation inss enactments through 1949. Our plan is to issue supplements at oximately 5-year intervals in order to include additional up-tolegislative actions.

index to the Reports of all National Conferences, from the first igh thirty-sixth, has been issued and is now available from the Government Printing Office. Its designation is NBS Miscelus Publication 203.

rs. K. M. Schwarz, our Attorney-Editor, has been working Ighout the past year on the Weights and Measures Case ReferBook. We hope to place this material in the hands of the GovernPrinting Office before the end of this summer.

ar plans for future publications include circulars on specific subas the need is indicated. NBS Circular 503, Statutory Netent Marking Requirements for Packages (Undefined) and Packof Foods, Drugs, and Cosmetics, is an example of this type ication.

ne activities of the States toward the adoption of the specificaI;, tolerances, and regulations for commercial weighing and measg devices, as contained in NBS Handbook 44, amended, has been 
gratifying. There are now 21 States that have officially promuly these provisions, and many others which plan to proceed with adoption. In a few States legislative action is required. MIost o: States are applying the code in their official inspections.

The States which have officially accepted the H44 codes wit. substantial change are Alabama, Florida, Georgia, Indiana, $\mathrm{Ka}$ Louisiana, Maine, Massachusetts, Michigan, Montana, Nevada, Jersey, North Dakota, Oklahoma, Oregon, Pennsylrania, Texas, mont, Virginia, West Virginia, and Wyoming.

In addition, the following States have taken initial steps and now in the process of officially adopting the codes: Illinois, Maryl New Hampshire, Tennessee, and Trisconsin.

In closing, I would like to extend to each of you an invitatio call freely on the National Bureau of Standards for assistance in solution of your technical problems. Te believe that the work are doing is of fundamental importance to the stability and stres of the Nation's commerce. Therefore, within the limits of our fi resources, we are at your service. Finally, please accept my wishes for both a profitable and an enjoyable series of discuss during this 37th National Conference on Weights and Measures.

(The chairman appointed the following committees to serve during the National Conference: Nominating committee, J. E. Brenton of Californi Chairman; C. A. Baker of New Yor's; J. F. Blickles of Pennsylrania; J. Jones of South Carolina; J. J. Leritt of Illinois ; C. C. Morgan of Gar'y, Indi and R. J. Zierten of Racine, Wis. Resolutions Committee, M. A. Nelso Michigan as Chairman; T. C. Beck of Oklahoma : A. C. Beckel' of Camden Cor New Jersey; Walter L. Daniels of Seattle, Wash.; J. E. Mahoney of Maryl M. G. Rice of New York; and Louis Snow of Bridgeport, Conn.)

\section{THE MEN WHO MAKE THE CONFERENCE}

(By W. E. SHeEHY, County Sealer of Weights and Measures, Bridgeport, Co

(Mr. Sheehy spoke extemporaneously and in a humorous rein. His covered many of the more important aspects of weights and measures adm tration and enforcement, and was both interesting and inspirational.)

\section{ROLL CALL OF STATES}

The Chairman called the roll of States. Delegates from $35 \mathrm{St}$ and the District of Columbia responded. All delegates and $t$ ladies were introduced indiridually.

(The Conference was recessed until 2 p. m.)

SECOND SESSION-AFTERNOON OF TUESDAY, MAY 20,

(G. H. Leithauser, Tice President, presiding)

\section{ROLL CALL OF STATE AND REGIONAL WEIGHTS AND MEASU ASSOCIATIONS}

The Chairman called the roll of State and Regional Associati of Weights and Measures Officials. Representatives of all $19 \mathrm{~A}$ crations on record responded.

(Written reports from several States and Associations were mimeographed distributed at the Conference.) 


\section{TOMATOES IN RETAIL GAR'TONS}

\section{A. Lros, Director, Dirision of Markets and Standards, State of New}

II ampshire

prevailing practice whereby tomatoes are packaged in a confaced with cellophane, constitutes packaging in a closed package. New Hampshire closed package law states: "It shall be unlawful $y$ person to sell or offer for sale any commodity in package form the contents thereof is expressed in terms oi net weight, measure, merical count in a conspicuous place on the outside of the package, lainly printed statement in large type."

en this type of package and method of marketing tomatoes leveloped, quantity marking was in terms of weight. 'This weight sually 15 to 16 ounces to the carton. It has been a growing pracin recent years to mark by numerical count, fours. fives, or sixes. inspection experience in New Hampshire, indicates that this od of marking has deteriorated to the extent that the actual count ackage varies from the expressed count appearing on the packIn addition, the size of the tomatoes in the pack varies, causing iance of weight.

insumer protection and individual State enforcement can best tained by uniform packag. marking requirements in all States. achievement of such uniform legislation should be encouraged fostered by this National Conference with the cooperation of ederal Food and Drug Administration.

have found packages containing five tomatoes marked four, ages of four tomatoes marked five, and packages of six tomatoes zed four or fire. The net weights ranged from 11 to 15 ounces. retailer and consumer are confused by these methods of package rings.

is confusion in merchandising and marking packages of tomatoes peen the concern of weights and measures officials in Massachuand New Hampshire for many months. The legitimate packers e area are 1ikewise aroused and are lending support to the requireof a weight statement. I few States, including Texas, have ired for sereral rears that packaged tomatoes be marked with ment of weight.

March 10, 1952, the following regulation was issued by the Hampshire Bureau of Weights and Measures: ". . . that coner protection will best be accomplished by expressing quantity unt of tomatoes in package form in terms of weight." The effecdate of this regulation shall be September 1, 1952.

o attempt is being made to standardize on any package. Reports ived from repackers indicate standardization on 12- and 14-ounce Trages. Possibly a 16-ounce package will be used.

he Massachusetts Department of Weights and Measures has issued nilar ruling to become effective on September 1, 1952.

he problem of more adequate and uniform control over the sale omatoes in retail cartons should be the concern of the National ference on Weights and Measures. The trade rolume of this type ackage is steadily increasing and is Nation-wide in scope.

R. Kexredy: The proposed Model Regulation on Package MarkRequirements provides for the marking of packages by count in ain instances. In the case of tomatoes, the consumer can see the 
merchandise she is buying. Do you not think a statement of numer count is sufficient?

Mr. Thompson: Mr. Lyon, I would like to ask if you had $\mathrm{m}$ trouble in getting the cooperation of your Attorney General in promulgation of this regulation.

Mr. Lron: Tre encountered no difficulty. The attitude is that count, as it refers to tomatoes in the package, does not give the ne sary information to the consumer. The consumer cannot make a comparison of value without knowing the weight of the product.

Mr. Mahoney : I carried on a limited informal survey on this it I found not one housewife who was interested in the weight c package of tomatoes. They were interested in quality, condition, uniformity of size.

Mr. McBride: We accept too readily, I think, the expressior quantity in terms of count. If we require that the expression quantity be in terms of weight, we can offer to the consumer utmost in informative declarations.

We have made surveys, and, as a result of them and the experif which we have had, it seems to us that the best way to protect consumer is to require the declaration of quantity in terms of wei;

Mr. Mundr: What is the attitude of the Federal Food and D Administration as to the method of marketing tomatoes in cartc

Mr. Rowe: I have been listening with interest to this discuss I am sure you will appreciate that it is a matter for debate. Tl are two sides to the question. The Federal Food and Drug Adn istration has not insisted upon a net-weight declaration. We have however, that there should be a survey to find out what the consu really thinks about the matter. The Federal law stipulates $t$ the statement of contents, which may be in terms of weight, meas or numerical count, shall be in the term that is used most gener: by the consumer and that gives an accurate declaration of the quan of content. We have been unable to determine just what is an accus determination in this case.

At the present time, while we have not insisted upon the net-wei declaration, we have given consideration to it and we are open-min about it. We have hoped to conduct a survey, but this has not $k$ done to date.

Mr. McBride: Has the Federal department indicated any tr as to what their thinking might be? This is a problem of I standing.

Mr. Rowe: 'The Food and Drug Administration has not as taken an official position. I do not think that should deter the Ste from going ahead with this matter.

Mr. Meek: In Indiana we require cartons of tomatoes to be labe in terms of net weight. We enforce that requirement under the $\mathrm{F}_{\mathrm{O}}$. Drug, and Cosmetic Act, which, in Indiana, is exactly the same as Federal Act. Both the Food and Drug Division and the Weig and Measures Division are in the Indiana State Board of Health. have, in company with others of the State Board, talked to $\mathrm{Mr}$. Qu. and others of the Federal Food and Drug Administration. We h: always had the impression that they look with favor upon the label of cartons of tomatoes in terms of net weight. We have interpre the Food and Drug Law of Indiana as requiring the labeling in ter of net weight, and we are receiving from 85 to 90 percent compliar 
$\mathrm{nk}$ it is a reasonable requirement, and I think it helps to protect ublic. I would like to see this Conference go on record as favorhe sale of this commodity by weight.

?. Greene: We directed a letter to W. A. Queen, Food and Drug inistration, April 15, and we received an answer on April 23, h referred to a letter dated January 14, 1948. I will read part as I think it is of interest to this Conference.

this Agency is anxious to proceed promptly against all practices which it ards as a violation of the law. Unfortunately its ability to do so is tricted, for it has limited facilities.

rirst, attention must, of course, be given to such abuses as the distribution impure matter, etc.

Before this Agency brings any action against interstate shipments of kaged tomatoes, we would want to be fortified with additional informa$n$ as to what constitutes accurate information as to quantity. This would essitate a consumer survey.

In view of our inability to divert action to the packaged tomato industry this time and since consumers do not have the opportunity to see the size d quality of such tomatoes, it is not our intention to institute regulatory ion at this time against such packaged tomatoes shipped by this firm ely for failure to bear a net-weight statement on the package. It is our rpose to make such a consumer survey just as soon as opportunity permits d appropriate announcement of our view on the labeling will be made.

dditional comment on the subject was added by Messis. Fisher, Crawford, zley, Mullen, Goode, Ising, Rafael, and Carey.)

he matter of tomatoes in paper cartons is included in the Report of the Conree Committee on Methods of Sale of Commodities. Additional discussion place after the presentation of this item by the Committee Chairman, beginon page 61 of this Report.)

\section{FLOUR WEIGHTS}

By G. F. Austin, JR.,

Deputy Sealer of Weights and Measures, Detroit, Michigan

Ve have before us, at this time, the discussion of flour weights. As know, this has been a very controversial subject for a long time, more especially of late, it has come to be a matter which has taken more serious aspect. The present rise of interest in this subject, refore, is not one based on a sudden impulse, but rather the climax long siege of restless dissatisfaction with a seemingly unwarranted lation.

Vith the passing of time, the public has become more and more ght and measure conscious, departments of weights and measures e become more numerous, and, with all of the facilities available ay to better acquaint weights and measures officials with their rensibilities, together with the excellent on-the-job training proms which abound, a more competent and thorough administration weights and measures affairs has come into being throughout the intry. Finally, and as a result, matters which have gone more or unattended heretofore are now coming into the spotlight, so to ak.

n dealing with the subject of flour weights, it is imperative that we give due credence to the problems of all parties concerned, the isumer, the retail store, the jobber, the flour manufacturer, and the ights and measures official. We should enter this discussion with open mind, free from prejudice, knowing well that it is a problem which there is little hope of attaining a panacea; therefore, any 
conclusion arrived at here will of necessity be the result of a com mise based on logical and sound reasoning:

Flour is an hyoloscopic substance, and, as a result, it contains ing amounts of moisture, depending upon relative humidity, tem ture, and length of time it is exposed. As a result of this character of flour, a particular sack of flour will vary in weight from tin time, depending upon the relative humidities and temperature which it has been exposed, such changes occurring as a result of sorption of moisture by the flour or evaporation of moisture in flour. The hygroscopic character of flour is a rell-recognized ment; however, for the purpose of this discussion, it is well to kee mind that the climatic condition to which flour is normally expe during its period of transportation and delivery to the ultimate sumer, is such as to cause a sharp loss in weight due to the evalpora of moisture.

'This being the case, it would seem only logical that some trans] ing and merchandising controls should be set up by properly stituted authority to assure the presence of " good distribution pract in the handling of this commodity. This has been done by the Fed Security Agency (Federal Food, Drug, and Cosmetic Act of Jum 1938, as amended, 21 U. S. C. A.-301 et seq.) for the purpose of in state commerce, which act reads in part as follows:

(k) Where the statement does not express the minimum quantity :

(1) Variations from the stated weight or measure shall be permitted caused by ordinary and customary exposure, after the food is introduced interstate commerce, to conditions which normally occur in good distribr practice and which unavoidably result in change of weight or measure.

Some State and local regulations, together with the Confer Committee on Legislation regulation as proposed in their tenta report, carry similar provisions to control "good distribution pract within their respective jurisdiction. The existence of these State local regulations where they do exist, and if enforced, would con the subject problem fairly well insofar as the jobber and the re store are concerned. However, there exists a basic problem involr the flour manufacturer against which these regulations are ineffec and which is really the prime concern of the moment. This b problem is that of finding some ways or means to encourage the $f$ manufacturer to orerpack a reasonable amount to take care of shrinkage which occurs quite immediately after the weighing op tion. Knowing well the common tendency for flour to lose moist rather than to absorb the same, in the normal course of distribut it would seem that the milling industry has a very definite respo bility in this matter and should take such steps as are necessar assure correct weights being maintained until, at least, the sale delivery have been completed at the initial destination.

In the City of Detroit, we have made several flour surveys over past few years, and, as an apparent result of this sustained vigila together with a little court action, we have improved the flour-wei. situation considerably. However, our last major survey, which completed about 6 months ago, revealed some interesting informat which I will discuss briefly at this time.

At $W$ arehouse Level. The flour reweighed, had been in transit storage for a period of from three to four days. We examined various brands, we reweighed 895 twenty-five-pound sacks, and 
an arerage minus error of 2.3 ounces (approximately one-lialf ercent).

Retail Level. The flour reweighed had been in stock for a period , m 3 to 4 weeks. TVe examined 11 various brands, we reweighed renty-fire-pound sacks, and we found an average minus error 3 ounces (approximately 1 percent).

of the important bits of information which highlighted this was that two of the leading national brands which constituted one-third of the rolume checked, had contributed most to the ge minus error. Had it not been for the lesser known brands ing an overweight average, the average minus error would have considerably greater. In light of the foregoing information, yite reasonable to presume that we, in Detroit, have our sights the next flour weight targets.

fore concluding my introduction of the subject "FLOUR GHTS," I shall quote from the report of the Committee on ods of Sale of Commodities, 31st National Conference on Weights Ieasures. This report can be found in NBS Miscellaneous Pubon M170 (1941). It reads as follows:

Tolerances should be reasonable and should allow for possible nkages in weight or measure due to atmospheric or other conditions. most serious question for our consideration was the establishment of cormity in the proper allowance for shrinkages. It is the consensus pinion of this committee that, for the purpose of determining the actual weight or measure of commodities, tolerance shall mean a permitted iation from the marked or indicated net content of a commodity. Such iations shall be as often abore as below. Commodities which show a ural shrinkage should be so orerpacked as to assure the housewife of receipt of the exact amount specified on the label at the time of sale to

A uniform shortage of all packages of one commodity sold by the same ker, though within the tolerance, should not be permitted...

2. Rheis: Last year we reweighed over 5,000 bags of flour, of h 40 percent were short weight. We met with 14 representatives e milling industry to discuss the problem. Their claim that the ture content had dropped from $141 / 2$ percent down to 8 or 9 perwas refuted by the records of laboratory analysis by one of the chain-store operators who had run samples. These records ated that in no case did the moisture content drop more than jercent.

e instituted, for a short time, a tolerance based upon the claims e millers, and reweighed an additional 3,000 packages. Allowing 1 the tolerance they requested. We still found 7 percent of the d samples short of declared weight.

hereafter we allowed no tolerance. From that time on, we have no short-reight flour in Cincinnati. Flour weights are being rolled by the millers, who weigh a carload when it leaves the weigh it again on a track scale in Cincinnati. They then open war and weigh individual packages.

uring the past year we have found not one bag of flour short in hit.

R. KExNEDT: I have been informed that, when flour is packed xport, it is packed $991 / 2$ pounds in a 100 -pound sack. I presume is to allow for a moisture increase during transit across the ocean. uld like to know if this is also the practice when flour is being ered in the United States. 
Mr. Acstix: I have found nothing that would bear out that cfie tention. We have only one mill in Detroit over which we can $\mathrm{m}$ observations.

I would like to suggest that the weights and measures officials jurisdictions where flour mills are in operation maintain a c supervision over the flour weights at the mills.

Mr. Knenvedr: Mr. Austin, do you feel that some allowance sho be made for shrinkage?

Mr. A Ustin: I do not think there should be any average allowar: I feel that the arerage net weight should be there. For an isola bag or two, I think that there should be a 1 percent tolerance. $\mathrm{T}$ is the limit of shortage or overage allowed on any individual pack: The arerage net weight must be correct.

Mr. Fakler: I am Vice President of the Millers National Fede tion, which is the national trade association of the flour mills industry.

We regard the problem of flour weights as a very serious one. regret shortages as much as you do. Our prime obligation is produce a product of quality, acceptable to the consumer, and reach the consumer in the proper quantity. We also feel that if have an obligation to comply with the laws and regulations. Wel! feel that those laws and the regulations must, of necessity, be rilf sonable, and we believe that the courts so hold.

In answer to Mr. Kennedy's question, I believe there is a practli in export of labeling gross weight. Therefore, the actual contentli flour will be less than the amount stated on the package. Thatli permissible and has long been the practice in export.

We are anxious to consider with you a proper solution of th problem, and, if it is agreeable to this organization, it would be $\mathrm{m}$ than agreeable to us to appoint a mutual committee representil your organization and the milling industry to work together to f a solution.

Mr. O. W. Gallaway: There are several factors which must taken into consideration regarding the variations in weights. I relative humidity is the big factor, since flour will absorb and 1 moisture. In a survey in the stores in 14 States, we found that 1 relative humidity throughout the year will average about 48 perce

If a store has a relative humidity of 36 percent and a temperature $71^{\circ} \mathrm{F}$, a 5 -pound sack of flour. Which has a moisture content of percent to start with, will lose 2.1 ounces, or 3.25 percent.

In another store, with an average relative humidity of 45 perce the 5-pound sack of flour will lose only half as much weight. Leavi it there for 7 days, it will lose 1.94 percent of its weight.

Those are about the average relative humidities in grocery sto] throughout the 14 States in which the tests were made.

Flour in transit by carload will also lose weight. In a box car $t$ top sacks will lose weight, while the sacks on the floor will weigh t same as they did when packed.

In the milling of flour, a constant moisture content is absolute necessary. If it is too dry, the particles of bran will break off a go into the flour. If it is too moist, the flour gums up and cannot sieved. So flour, at the time of manufacture, is different from a other commodity. It must, from a milling standpoint, be one cc: sistent moisture and temperature at all times. 
he problem is a real one, since flour is so affected by the surroundhumidity. I might give an illustration. In one large store they id all flour weighing short-very much short. We refused to take flour back, and we suggested that they place the flour in a back n. After it had lain in the back room for a week, every sack was -weight.

$t$ what point would you say it was proper to weigh this flour?

the State of California, sacks of flour were weighed each week 52 weeks. During those 52 weeks, at no time did the sack weigh the in two successive weeks. Some weeks the weight would be up, e down.

e maintain that the only place to control the weight of flour is at mill. All mills are controlled and regulated by the States, both as acking and as to weights. Further, the transportation agencies e in and weigh the flour from two to three times each year. They t to get an average of what each sack will weigh. That is how freight charges are arrived at.

Te feel that the only logical place to weigh flour is at the mill, or $\mathrm{n}$ it arrives at destination.

IR. MCBRIDE: What is the moisture content of the product at the I ?

IR. GALLAWAY: It runs around $131 / 2$ to 14 percent.

IR. MCBRIDE: Is that true of all mills?

IR. Gallaway: Yes, otherwise the flour cannot be milled.

IR. MCBRIDE: Is there a constant temperature at which you pack?

Ir. Gallaway: Usually at the mill the flour is coming out at $92^{\circ} \mathrm{F}$.

IR. McBride: If we could simulate mill conditions as to relative nidity and temperature, we could probably arrive at the same ght.

Ir. Gallaway: You would come back to the same weight as when flour was packed.

Ir. Schuster: Our city (Buffalo, N. Y.) has in recent years passed neapolis as a flour center. We do weigh flour at the mill, and in the field. While the flour weights do vary in the field, the mill ghts are pretty fair. They have their scales tested periodically, sibly every 6 weeks.

1R. Ackerman: Probably five or six times a year we go to the mills our district and check all sizes of packages. In the last 5 years we te had nothing but OK's for the milling companies.

Ir. Adstiv : Could we have a comment from the industry regardwhat we know as the heart of the problem? That is, an over$\mathrm{k}$ at the mill to take care of the normal shrinkage in the early ges of transportation and delivery.

[R. FAKLER: That is a problem that has been given very serious sideration by the industry. It involves, however, a number of H)blems. First, there is the economic problem. An overpack does rease the cost, and it will increase the cost to the consumer. There ilso a problem in connection with transportation. An overpack ght solve the shortages in a short distance or a short time, but the $\mathrm{t}$ judgment of the industry is that it does not solve the problem -manently.

Jhairman Leithauser: I would like to suggest that our incoming sident consider the suggestion of the industry and that he desige the proper committee to work with the milling industry. 


\section{SHOULD WORD "NE'T" BE MANDATORY IN QUANTITY STATEMEN}

Br J. F. Blickley, Director, Burean of Standard Weights and Measures, Commonvealth of Pemsylvania

Since our last Conference, the question as to whether or not the wo "net" be included in all quantity statements on commodities in par age form has been brought to the attention of some weights and me: ures officials for an official ruling. In Pennsylvania I have be requested on many occasions to rule on this subject; my decision h always been that the word "net" must be part of the quantity sta1 ment. Many other State officials have the same opinion and ha ruled in the same manner and have insisted that the word be part the quantity statement.

Unfortunately, some few manufacturers and processors of commor ties take exception to these rulings and insist that the laws are col plied with when the quantity is declared. If the language of Secti 22 of the Model Law, as revised and recommended by the 36th $\mathrm{N}$ tional Conference on Weights and Measures in 1951, were part of : State laws, there would be no further need for discussing this subje for commodities sold on a weight basis; this section specifically defin the word "weight," and I quote Section 22 of the Model Law:

That the word "weight" as used in the Act in connection with any commodity shall mean net weight. Whenerer any commodity is sold on the basis of weight, the net weight of the commodity shall be employed, and all contracts concerning commodities shall be so construed.

This removes all doubt as to the actual meaning of the word "weigh if the word "net" were not included in the quantity statement.

Section 19 of the Model Law is also very specific in stating th 6*** any commodity in package form shall bear on the outsir of the package a definite, plain, and conspicuous declaration (1) the net quantity of the contents in terms of weight, measure, count

Many State laws were on the statute books before the Model La was revised and recommended to the various States for adoption. States where the provisions of the law are not as specific as the Mod Law, it may be necessary to seek clarification by legislation, especial] where decisions of the proper anthority are disputed or ignorerl.

With the thought in mind of adding to the clarification of the sul ject, permit me to cite my experience.

The decision that the word "net" must be used in quantity statemen was disputed by some manufacturers. In order to settle the disput I sought the advice of our Department of Justice and requested formal opinion as to whether Section 7 of our Commodity Law mac it mandatory to use the word "net" with quantity statements. Th section of the law reads as follows:

No person shall distribute or sell or have in his possession with intent to distribute or sell any commodity in package form, unless the net quantity of the contents shall be plainly and conspicuously marked on the outside of the package in terms of weight, measure or numerical count.

(Word for word, it is not exactly the same as the Model Law; however, $\mathrm{tl}^{\text {t }}$ meaning is exactly the same.)

That a careful study was made and extreme caution used in delibei ations before opinion was rendered is manifested by the citations of various court decisions in the United States. The opinion cites a cas from the State of Indiana in 1890, one from the State of Washingto in 1906, one from the State of California in 1942, and another fror 
State of Washington in 1913 which I think is worth nentioning art of this subject to justify our decisions.

manufacturer of a commodity, who was prosecuter muder an inance requiring the net weight of the contents to be stamped on tainers, made the defense that he had complied sufficiently with the by stamping the weight of the contents when packed.

the Court in the City of Seattle, IVashington, held as follows:

* Many other like rulings might be cited to the effect that what te law will imply as a necessary incident is as much within a legislative actment, whether state or municipal, as though specifically set forth in 1.ms. And it is not a departure from such a rule to say that a requireient to stamp the net weight on a container is implied from the power to gulate weights. It is a regulation and one of the most effective in so gulating weights and measures as to reduce the opportunities for fraud nd deception to the consumer to a minimum.

* * * It is not unreasonable to require that the packer and manufacturer all ascertain this loss by evaporation as he is best in position to do, and rercome the loss by increasing the size of the package or the weight of the mmodity packed therein, or withhold his goods from the market until it possible to ascertain the true net weight. Whatever may be the necessary: ourse to adopt to enable the container to correctly indicate the weight of the ommodity it contains, it is not unreasonable to place that burden upon the ne who puts the article before the public as a sale commodity, and compel $\mathrm{im}$, if he wishes to retain his trade, to so pack his commodities that the onsumer may know the true quantity of the thing he buys, and thus protect imself in paying the value of the thing he buys.

The opinion also cites the definition of the words "Net Weight" as scribed in Blacks Law Dictionary De Luxe, 3d edition 1940, which is follows:

Net Weight. The weight of an article or collection of articles, after deductng from the gross weight the weight of the boxes, coverings, casks, etc., conaining the same. The weisht of an animal dressed for sale, after rejecting nide, offal, etc.

The opinion as rendered by the Pennsylvania Attorney General ids as follows:

If the word "net" is omitted from the description of the quantity of a ommodity enclosed in a container, confusion would arise in the mind of the - uyer as to the actual rolume of weight of the commodity in the package, tnd give rise to possibilities for fraud.

The statute directs in no uncertain terms that the net quantity of the contents is marked on the outside of the package, and it follows to mark the jackage as to the quantity of the commodity contained therein, without "ncluding the word "net" would amount to a failure to comply with the mandaory direction of the statute.

It is our opinion, and you are, therefore, accordingly adrised that the word "net" must be included in all quantity declarations required under section $\tau$ of the Commodity Law.

It has always been my personal opinion that when the words "net ntents" or "net weight" are used in the law, it was the purpose and tent of the law to use the word "net" in conjunction with the declaraon ; this opinion was sustained by the ruling of the Attorney General Pennsylvania and further resolved by judicial determination.

Weights and measures officials have always construed the quantity atement to represent the net contents of the package, regardless if e word "net" was included in the statement or not.

It is very apparent that, at the present time in a few cases, state"ents that do not include the word "net" are being purposely misconrued as a method of evading the intent of the statute. 
Wherever laws are worded properly, it may not be essential include the word "net"; however, it certainly can do no harm if it included in the statement. If quantity statements are misconstr for the reason that the existing statute of the jurisdiction is not $\mathrm{s}$ cific, weights and measures officials who have been delegated with responsibility of consumer protection should secure clarification.

As this has now entered the field of controversy, whenever statu are being amended or rewritten, it may be well for all weights a measures officials to include a change in their statute, making the of the woud "net" compulsory in all quantity statements. It certai will not impose a hardship on any industry. It surely will relieve of another problem and will enable us to devote our time to $n$ problems that are forever confronting us.

Mr. Kennedy: Would it not be well to amend the Model State $\mathbf{L}$ on Weights and Measures, by moving the word "net" in Section so that it would read, "Any commodity in package form shall b on the outside a definite declaration of the quantity of contents terms of net weight."

Mr. Buickify: That is a good suggestion for the Legislat Committee.

\section{STANDARDIZATION OF FOOD PACKAGES}

BY I. M. Levy, Sealer of Weights and Measures, Chicago, Illinois

Standardization of weights for prepackaged foods is not a n subject. It has held the serious attention of weights and measu officials for many years; and, while no over-all State or Natio Jaw has been enacted, it can be said that progress has been made in general direction of standardization-notably, State and local bre laws, laws pertaining to milk containers, and those which regulate 1 size of berries and small fruit containers. But we are far short of c ultimate goal. Modern distribution methods tend more and m. toward prepackaging. The old cracker barrel has long lost its $p$ turesque place in the grocery store, and in its stead are displays brightly colored cartons of crackers and cookies. Cereals, likewi have come out of their bins and are sold in cardboard and paper $\mathrm{ce}$ tainers, with the weights printed on each, but what a variety weights-such as $71 / 2$ ounces, $73 / 8$ ounces, $33 / 8$ ounces! The same c be said for a long list of other commodities.

Let us, for the moment, consider ordinary uncooked grain rice. one store, I found the following sized packages: 1 pound 15 ounc 14 ounces, and 5 ounces. Another example, peanut butter, a process item, the packaged welght of which is completely under the cont: of the packer. Again, what did I find in the supermarkets- the $\mathrm{f}$. lowing glass containers: 15 ounces, 14 ounces, 13 ounces, 12 ounc 11 ounces, 9 ounces, 8 ounces, 5 ounces; and in one store, a $51 / 2$-our jar. All of these brands are well-known, nationally advertis products.

At this point, I wish to state briefly the case for standardiz weights of prepackaged foods. It is my belief that it would be in $t$ public interest if prepackaged food products were sold in standa units of weights and that the sale of the same prepackaged commor ties would be prohibited were they not of the weights prescribed law. By the public interest, I mean it in an all-embracing sense the processor, the packer, the wholesaler, and the retailer, as well, 
consumer, would be the beneficiaries of a fair, equitable, and wellned law. The free flow of commodities from and into all sections ur country necessitate that the laws and regulations be on a onal level.

he consumer, typified by the woman shopper for foodstuffs, is stomed to buying in standard units of weights, represented by pound or generally accepted subunits of the pound, such as $1 / 2$ or $1 / 4$ nd. When a package placed on the grocer's shelf equals or apsimates in size a pound container, but is labeled 15 ounces, it is the most discerning shopper who, by scrutinizing the label, will the difference.

the purchasing of packaged commodities by the consumer, there marked tendency to buy by size, to call for a "small package of or a "large package of that." This is another reason why the nan shopper should be able to buy with confidence in the knowledge all brands of the same item will be the identical net weight. We, reights and measures, who constantly advocate exactness in all isactions by weight, must frown upon any practice which underes this fundamental principle. We strive by every means of eduon and publicity to impress upon the shopper the wisdom of buying veight, of watching the scale, of asking the price per pound, so that knows that she is getting all for which she pays. It is true that eral laws require that the net weight be printed on the package, I am sure that I need not develop a case among you gentlemen how ring in visibility are the hidden weight markings on so many of our kaged food products. May I mildly put it that they are not conive to encouraging Mrs. Careful Housewife to watch her pounds ounces.

The greatest evil which accrues from lack of standardization is a fusion in the customer's mind as to the best buy, when there are a iety of brands of the same product and when there are two varies-weights and prices. Let us give a couple of illustrations. In store that I recently visited, there were three brands of apple sauce, labeled 1 pound 4 ounces, priced at 19 cents; another 1 pound 1 ice, priced at 16 cents; the third 1 pound at 14 cents. Which ofed the best buy, quantity only considered? I will not claim this se an intricate mathematical problem, but, on the other hand, I am fident that the average shopper will not spend the time necessary letermine the best value. Let us take another illustration. In the he store, I noted two well-known brands of macaroni. One was a unce package at 11 cents, the other an 8-ounce package at 14 cents. ain, I ask which brand gives the most macaroni for Mrs. Housete's money? And, again I say, Mrs. Average Housewife either ild not or would not take the time to figure it out. Just imagine at goes on in her mind when she is confronted with labels marked ounces, $61 / 2$ ounces, $41 / 2$ ounces, 141/2 ounces, 9 ounces, 11 ounces, ounces, $51 / 2$ ounces. These are actual label markings taken from ew common items which I chose at random in one store and include feals, condensed milk, mustard, and relishes. A vast number of imples too numerable to mention could be given.

WV have noted the progress in prepackaged foods; keeping pace th this trend is the advance of the self-service stores. Neatly arged cans and packages are stacked on the shelves awaiting Mrs. nerican Housewife's choice. But she is strictly on her own. The 
prices are displayed and the weights are on the labels; but if thr weights were always comparable among brands, the thrifty shop1 would be in a position to determine the best value, that is, as in rega to quantity in standardized weights. This is the only practical mea by which to gain this worthy objective.

A manufacturer may discharge his legal obligations by setting for the net content of the package on the label, but I camnot a gree that it realistic or reasonable that the average housewife be confronted confused by odd and out of ordinary weights on packages. In important case, a Federal judge charged the jury as follows:

The law requires a manufacturer to be honest in his statement of the con tents of a package containing a food product and it requires him to be hones in stating the truth of the labels put on it. It is the purchasing public. th ultimate consumer, whom the provisions of the law are primarily intender to protect. The law is not made for the potection of experts, but for th. people, that vast multitude which includes the innorant, the unthinking anc the credulous who in making purchases do not stop to analyze but are gov erned by appearances and general impression. It makes no difference tha dealers in the article are not deceived. It is the probable inexperience of the customer that you should consider.

Now let us consider standardization from the seller's viewpoil Why is there such a hodgepodge of weights in prepackaged foodstuff I shall not attempt to enumerate the various reasons given, but I w relate what appear to be the most common ones. I manufacturer processor, or possibly a large retailer possessed of a desire to incre: the sale of one of his items will reduce the quantity in the container that the price will be below his competitor, or he may desire to mai tain a standard price which he could not otherwise do unless the qua tity is reduced. The second reason has, of course, almost ranish because of recently widely fluctuating costs and prices. Sometimes more acceptable reason is given. A package is developed to vield certain number of servings that it may better meet the needs of $t$ average family. Frankly, while not wishing to tangle with the exper in the field of home economics, I am not convinced that this reason a ralid one, except in a comparatively few instances.

I think it is not farfetched to conclude that, in many cases of or and fractional weights, the sales, rather than the production, $d$ partment was dominant, at least in the original weight determinatio Of course, when production facilities are once set up for certain siz and weights-ovens, forms, and filling machines-then it would costly to make changes. But in the long run, the more numerous pac age sizes necessitate larger container inventories and the increased $u$ of storage facilities. It further means more frequent adjustments machinery. All of these factors add up to increased production cos: erentually paid by the consumer.

TVe made a survey among some food processors and manufacture in Chicago, and, while we admit it was too cursory and localized to 7 conclusive, I believe that there are equally as many manufacturer's w] would welcome the proposed regulations as those who would oppo them. Furthermore, practically every manufacturer who was in $o^{\text {t }}$ position gave as his reason that the present equipment could not me the proposed changes, but he did not object in principle.

Of course, I do not advocate that there be any standardization packaged foodstuffs other than that of weight and the standards s inp to meet the requirements of the pure food laws. The Americe system of free competitive enterprise is the best system in the worl 
there is still plenty of room for good aggressive merchandising if do have national standardized weight laws. Quality, consumer ference, price differentials, attractive and convenient packaging the elements, and it has been the honest and progressive use of e elements which have made our American businessmen world lers in their respective fields.

summary of objectives would be that an agency of government be owered by national legislation to strive towards ultimate standization. I certainly could not advocate that there be an abrupt sudden impact upon the American food industry.

believe that a gradual advance should be made over a sufficient iod of time for the changes, and I am thinking in terms of years. have a number of industries now who in actual practice have standized upon certain weights. When the overwhelming majority of industry produces, for example, a 1-pound package, then it should standardized and become part of the law, and those companies uld be given protection against others who would divert to unusual kage weights near the set standard. After a suflicient period of e, without dislocating any particular food industry, I believe that elimination of unnecessary and unwise packages would be acplished, and there would remain those weights which would be icient from a manufacturer's and consumer's standpoint.

This brief discussion has but opened the door to a vast and extremely ortant subject. There is much work ahead. I speak with admirafor the splendid pioneer work and fine contributions made by mbers of this Conference a decade or more ago. Perhaps it was war conditions which produced the intervening sommolent attie, but I do hope that we will revitalize the whole matter, and, even ugh the road may be long, difficult, and beset with obstacles, we uld carry the torch of duty to ultimate success.

Mr. Meer: Weights and measures people all are in favor of packstandardization if and when it can be brought about. I think most familiar with the efforts made by the National Conference a numof years ago to promote food package standardization. At that ie I was Chairman of the Conference Committee on Legislation. held a meeting in Indianapolis, and Mr. Blickley attended this eting as a member of the committee. I think we had about 40 or 50 lustries represented. They presented many arguments and reasons y they could not go along with the idea.

However, the Legislative Committee did report a food package ndardization bill (Report of the 33d National Conference, 1947). action of the Conference at that time, this proposed bill was left in hands of the committe for further consideration, the idea being it it would be brought out when there was sufficient public demand, when we could show that industry was in a position to go along with d package standardization.

[ am wholeheartedly in favor of it. I am aware of the arguments ainst it. I am also familiar with many of the reasons why such islation would be highly advantageous to the public.

Mr. Blickley: I had the pleasure of serving with Mr. Meek on that nmittee, and some or the arguments against standardization of food ckages were somewhat ridiculous. At that time conditions were atic in the country, and I believe the time was not ripe to put this itter in the hands of industry. I think that condition has now 
passed. Perhaps it would be a good idea if this 37 th National Conft ence on Weights and Measures would again revive the food packa standardization bill. I submit that as a suggestion to the Conferen.

Mr. 'Thompson: I would like to ask Mr. Levy if he has any su gestions from his research as to what steps could be taken towa this uniformity in packaging.

Mr. Levr: I think the first step is one of gaining public support. get the public to realize what this means in dollars and cents. I thi a very fine suggestion has been made by Mr. Blickley that this Conf ence go on record adrocating that work be done toward this goal.

I have gone through the record and I find that members of this $\mathrm{Co}$ ference did a fine job to arouse interest. I believe that, because $t$ time was not opportune, and the intervening war years took $\mathrm{c}$ attention to other matters which were more urgent, this project fell the way. I think it should be revived, and the first step is to follow $t$ suggestion of Mr. Blickley. From that point on, we should have educational program.

Mr. Buickley: I will move that this Conference go on record being in favor of reviving the effort toward standardization of fo in package form, and that this matter be brought to the attention the interested parties.

(The motion carried unanimously.)

Mr. Blickley: Many industries at our meeting in Indianapo indicated that standardization could not be accomplished, that it $\pi$ impossible. Two or three years later, the members of the flour ind try went before the States and requested that their product be stan ardized as to weights of packages. I believe that flour packages : now standard weights in some 40 or more States. If the flour indust can do this, I do not see why any of the other food industries canı do likewise. 1952.)

(The Conference adjourned, to reconvene at 10 a. m. Wednesday, May

THIRD SESSION-MORNING OF WEDNESDAY, MAY 21, 19

(E. R. Fisher, Vice President, presiding)

\section{REPORT OF THE COMMITTEE ON TRADING BY WEIGHT, PRESENT BY J. FRED TRUE, CHAIRMAN}

The Committee on trading by weight has found that there is $\mathrm{cc}$ siderable interest in doing away with the weight per bushel on ma commodities.

At the present time there is some confusion in buying ear co because of moisture content in the cob. The only solution to tl problem is to sell ear corn by the pound or hundredweight. grains which are now sold by the bushel can be sold by the pound hundred weight. Grain which is re-sold to the consumer after it 1 been milled whether mixed or unmixed with other grains is now sc by the pound or hundredweight. There is considerable difference the legal weight per bushel of apples and other fruits among $t$ States. This error can be corrected if the bushel is used only as volume measure. The weight for a given volume of apples or fru varies with the size and condition of the fruit.

We recommend that the committee be continued, that furth study be made, and that the State and Federal Agencies be encor 
to use the hundred weight rather than the bushel in their reports forecasts.

further recommend that machinery companies be encouraged to the rates of seeding to show pounds per acre rather than bushels pecks.

e recommend that each State introduce a bill in its next legise that will do away with the weight per bushel for all comities.

he report of the Committee on Trading by Weight was adopted by the erence.)

RESS BY E. C. CRITTENDEN, CONSULTANT TO THE OFFICIE OF THE DIREGTOR, NATIONAL BUREAU OF STANDARDS

sere is proposed an international organization intended to obtain degree of uniformity in the regulation of practical weights and ures in European countries. There is already an international nization which provides for uniformity in basic standards of surement. 'The top body in that organization is the General Connce on Weights and Measures which was established by treaty in and now includes 33 countries. Under the General Conference a ave the International Committee on Weights and Measures and International Bureau of Teights and Measures. The Internaal Bureau is a laboratory located at Sèrres, just outside of Paris, heeps the prototype international standards and periodically pares national standards with them.

he International Bureau thus provides, internationalìy, a service lar to that given by the laboratories of the National Bureau of dards in comnection with weights and measures in this country, it has neither authority nor means to do anything about trade tices in the various countries. Each country has its own weights measures service, and it has been long recognized that the diversity ractice which exists among European countries is a serious handi-

or instance, our own Miutual Security Administration and other ernment organizations which are encouraging collaboration been European countries to strengthen them industrially have urged removal of barriers to permit freedom of exchange of goods. Cuss barriers are a very serious obstacle to the effective use of the comic resources of those countries, and diversity of practice in ard to packaging, weighing, and other trade requirements add her difficulties. Recognizing that handicap, there have been disions for many years of the need for some organization like yours, uding officials of the different countries, as your Conference does e of States, counties, and cities, to bring about uniformity of pracin regulations and to remore some of the obstacles to trade across rnational boundaries.

o in 1937 the French Government called a formal international ference to consider this question. It was proposed to establish an fanization which might begin by collecting information about the gious rules and regulations and then draw up model laws and regufons, just as you have done in this country. Finally, it might even $\mathrm{g}$ about joint approval of equipment, because in Europe they go h further than we do in requiring approral of types of measuring ices, and the fact that each country has its own types limits the 
market of manufacturers rery severely. That is particularly tip because in Europe the same organizations usually cover not merely t] ordinary weights and measures but also gas and electricity meter which are, of course, widely used.

The 1937 conference was attended by representatives of 37 countrie The widespread interest was evidenced by the fact that those countri ranged alphabetically from Afghanistan to Yugoslavia. Horreve many representatives were diplomatic staff men who knew nothir about the subject; when they got down to real business, delegates of: countries, including all the important countries of Europe, signe resolutions looking to the establishment of an international organiz tion, and set up a committee to draw up definite plans for it.

Following 1937 there came various troubles. The Chairman of $t$. organizing committee was a Polish official. Poland got in troub right away, the war broke out in 1939, and nothing further was dor. about the proposed organization until 1948. The proposal was the revived at the meeting of the General Conference on Weights ar Neasures, but of the original 15 members of the organizing committs only 5 had survired or retained their connection with weights ar: measures.

A meeting was called for 1950 ; by that time the Communists ha orerrum Poland and thrown out of office the man who had been hes of the organizing committee. So a fresh start was made with a ne chairman, from Belgium. Ten countries were represented at the 19: meeting: 4 of the original 15 members were present. The committ has now prepared a draft of a proposed treaty to set up an organiz tion and it will be considered at a meeting in Brussels in October.

approved it will be sent out formally by the French Government, ar maybe in the course of a few years there will be set up an internation organization to do, in European countries and other parts of tl world, much the same job that you gentlemen are doing here.

Thether this comntry should join or not is a matter to be decided $k$ the Department of State and the Senate. Nearly all the other cou: tries use the metric srstem of weights and measures. This, in additic to our distance, the difference of our customs and requirements, al the absence of a national weights and measures service, makes it doul, ful whether we can take an effective part, but it may be worth whi for our country to take part, at least as an observer, to give such he as we can, and also to see that no rules or regulations are set up th: may handicap our manufacturers or exporters unduly. If and whe an organization develops, the details will be reported to you at lat meetings, and presumably your advice will be sought regardir participation in it.

\section{FARM HOLDING TANKS}

Br H. J. MCDADE, Sealer of Weights and Mlcasures, San Diego, California

In preparing this paper, I assumed that many among you are ne acquainted with the use or the procedure employed by the weigh and measures official in testing such tanks.

Farm holding tanks represent a great forward stride in the mea urement and handling of wholesale quantities of commercial mil between the producer and the processor or creamery.

At present, there are two types of these tanks in use in Californi namely, the conventional farm holding tank and the cold-wall tan 
se tanks range in size from 300 to 3,000 gallons, and I am informed t some are even larger. The conventional tank is constructed with outer wall around the stainless-steel measuring vat, allowing apximately 3 inches for jnsulation. The milk is cooled and aerater ore it flows into the tank. 'This type of tank will hold a quantity ailk for about 10 hours with a change of temperature not exceeding a. F

he cold-wall, or refrigerated, tank (see fig.1) is like the convenal tank, except that, in addition to the insulation in the walls of tank, refrigerating coils also are used. 'There is also a trough ning around the top of the tank with small holes through which milk trickles and is aerated and cooled right in the tank itself. 'hese two types are further divided into the glass gage and the suring-stick types, either of which is satisfactory. When filling glass-gage type with milk, the glass gage is kept closed by a valve he bottom and is not allowed to fill until the reading is to be taken. is then opened wide, allowing the milk to enter the tube with a ge, going beyond the true level and then settling back. This proure gives you an accurate reading. Te must keep in mind, how$\mathrm{l}$, that, milk being an opaque liquid, all readings must be made the top of the meniscus and not at the bottom.

Ve have learned that, if the tube is left open and the milk allowed reep up the tube as the tank is filled, the milk will stick in the dry e, and the reading may be one graduation less than a true reading. der the present California code, which limits the volumetric value these graduations, a one-graduation error might be equal to as ich as 2 gallons for tanks having a calibrated capacity in excess of gallons. For tanks of lesser capacity the resulting error might rqual to 1 gallon.

the measuring-stick type is preferred by some, for various reasons,

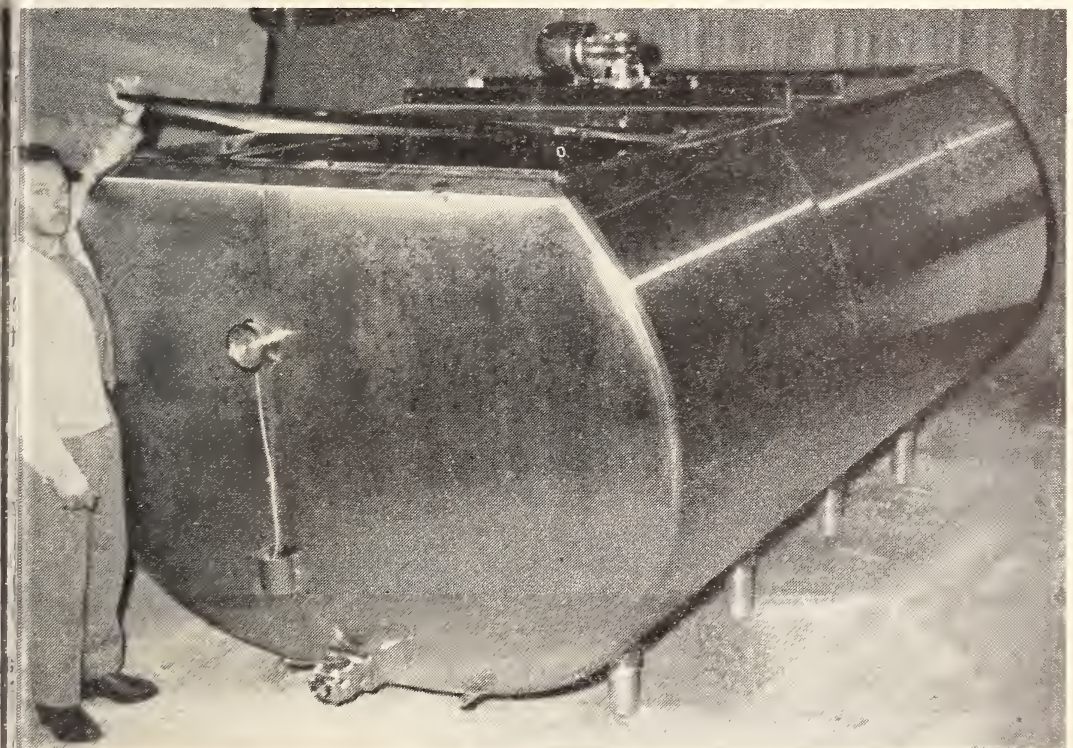

Figure 1. Farm holding tank.

Refrigerated, or cold-wall, type. 
one being the greater ease of cleaning as compared to the glass ga another, the freedom from danger of breakage.

In measuring the quality of milk with the gage stick, the stick not put into the tank until the measurement is to be taken, thus obta ing a measurement of the greatest possible accuracy.

Both types of tanks are equipped with a power-driven agitat which is used to thoroughly mix the cream, which has risen to the $t_{1}$ back into the milk, so that a representative sample can be taken a butter-fat test. It is of the greatest importance, however, that 1 agitator not be started until after the milk has been measured. 'To so would create a turbulence in the tank and incorporate air into 1 milk, which would result in an inaccurate reading. I might add tl all measurements are made by the driver of the tank truck, who, haw in California, must be a licensed and bonded sampler and weigh

The graduations on both the measuring rod and the column gl: gage are in terms of inches or fractions of an inch. The measurems on the gage is then referred to a chart that has been prepared by $t$ snanufacturer or his agent, which converts each graduation into ter of liquid measure.

Both the gage and the chart are integral parts of the tank, and ea must be carefully inspected, compared, and sealed. In testing a tar the weights and measures official compares his findings with the me: uring device, whether it be a gage glass or a measuring rod, and t chart as prepared by the maker. Under no conditions does he ma the capacity indications on either the glass gage, measuring stick, chart. It is the duty of the reights and measures inspector to veri that the respective indications conform to known standard measu ments. For him to mark the graduations on the gage or chart wor le as improper as it would be for him to place or locate the weig indications on the beam or chart of a scale.

'To give you a comparison of the accuracy of the farm holding tat as compared to the practice of measuring by the 10-gallon milk c method, which was universally used before the advent of farm holdi tanks, I offer you the following: Allowing for an elror of one grad ation in reading either the measuring stick or gage glass, the fal holding tank will measure 1,000 gallons of milk with a maxim error of 2 gallons per 1,000 .

Records of creameries show that, in California, milk purchased the creameries in 10 gallon cans averaged only $97 / 8$ gallons per ca yet they were paying for 10 gallons. 'This short measure was due excess foam and dents in the cans, and equals 12.5 gallons per 1,0 .

No one can successfully challenge the adrantage of the holding-taj method of handling milk from the point of accuracy of measureme which is, of comrse, onr chief concern. There is, moreover, the ard tional advantage of improved sanitation in this method of handling. the milk being kept at a temperatme of between $40^{\circ}$ and $50^{\circ} \mathrm{F}$., $11 \mathrm{~m}$. it is picked up by the stain less-steel insulated tanker, which will deliv the milk to the creamery, even over the longest hauls, with a change temperature not exceeding $1^{\circ} \mathrm{F}$.

When farm holding tanks were first introduced in Californ weights and measures officials were called upon to test and seal the 'This we refused to do, they being subdivided measures and, as suc not entitled to our approval.

'The milk industry and milk-tank manufacturers were persistent 
r request that regulations be promulgated to legalize this mothod neasurement. They wanted the feeling of security that goes with use of weighing and measuring equipment that has been adequately ed and sealed by a competent authority.

fter many meetings with representatives of both the milk industry manufacturers of farm holding tanks, rules and regulations, toleres, and specifications were drawn by James E. Brenton, Chief of the eau of Weights and Measures in California. Then, after a formal ring, these regulations, etc., were approved and became effective in ifornia.

ollowing the presentation of this paper, a number of slides were shown ly McDade and J. E. Brenton. These slides depicted various types of farm ing tanks and testing equipments. In the discussion, points were raised rding (1) the possibility of frost heave in cold climates, (2) the difficulty in ining rapid and accurate readings on stainless steel gage sticks, (3) methods istening tanks to foundations, (4) methods of testing, (5) manufacturers' onsibilities, and (6) the possibility of sale by weight from farm holding S.)

\section{THE MEASUREMENT OF PETROLEUM}

By E. L. Hoffyan, Socony-Vacuum Oil Co., Inc., New York, N. Y.

Ir. Chairman, members and guests of the National Conference on ghts and Measures, I would like to express my appreciation for kind invitation extended to me by Mr. Bussey to address you today he subject "The Measurement of Petroleun." In my talk I will uss some of the history of petroleum, the necessity for accurate surements and also comment upon measuring practices in use iy.

et me take you back to the first measurement of petroleum in this try; to Saturday, August 28, 1859. You will recall that the first rell was driven by Colonel Drake at Titusville, Pa. On that day Drake well had reached 69 feet and drilling had been stopped at point. On Sunday morning, "Uncle" Billy Smith, the driller, a look down the rell and found a liquid standing in the pipe quite the surface. He dipped some up and it was petroleum. He sent d to Colonel Drake in Titusville and borrowed Mrs. Smith's tub wash boiler and kept on dipping. By the time Colonel Drake red, every ressel at the site was filled with oil. The next morning, nel Drake started to search Titusville for empty whisky barrels. collected a dozen or so and rushed them back to the well, but they all filled by sundown. These whiskey barrels were made of d with a capacity of 42 gallons - 2 gallons of the 42 being allowed tare or leakage. This works out to a rough "tolerance" of 2 parts 2 , so you can see what progress has been made in "tolerance" since e days.

s the news of the Drake well spread, thousands of promoters and sans poured into Titusville, and soon hundreds of wells were lucing oil. 'The problem of containers was critical from the outThe wooden barrel was all that was available and the barrel faces worked night and day to keep up with the flood of oil. But e wooden barrels leaked more with oil than they did with whisky inegar, because the oil had little effect upon the wood, whereas whisky and vinegar caused it to swell. 'To improve accuracy of surement by reducing leakage, the infant oil industry attempted to ten up the wooden barrel, thus laying the foundation at this 
carly date for a sustained effort for somnd measurement. 'The Repr of the Commissioner" of Patents for the rear 1863 stated, "Fourte patents have been issued for more oil-tight barrels, besides as ma for tanks and cans."

As an illustration of the growth and rapid expansion of the pet Jeum industry, in 1920 the quantity of crude oil produced in the Unit States was $1 \dot{8} .603 .000,000$ gallons, while in 1950 this quantity was 8 $890,000,000$ gallons or over four times greater than in 1920. If quantity handled had been contained in a pipeline the same size as $t$ "Big Inch", its length would be sufficient to encircle the earth abc 2.) times at the equator.

As evidence of the magnitude of the demand for petroleum and products, I need only remind you that during the four days of $t$ meeting of this Conference, the petroleum industry will measure or 1 billion gallons of crude petroleum and then remeasure it about to 25 times on its way to the customer. The complications in many these measurement operations are considerable. There are over 1,0 rarious kinds of crude oil, some so thick ther flow like the heaviest $n$ lasses and some so thin they flow like water. The distance from $t$ center of production to the center of consumption averages over 6 miles and mar range as high as 8.500 miles, as in the delivery of cru oil from Arabia. Over this distance it may move by pipeline, tank barge, tank car or truck, or a combination of these methods. F each movement in each converance. it must be measured. It mu also be measured many times on its way through the refineries a through the storage terminals. While it will only be possible for $]$ to describe these measurement operations in general. I direct rou tention to the fact that perhaps 90 percent of them take place, in si cession, prior to the sale to the customer and thus form a gener procedure for an over-all check of crude oil from the well to finish products in the customer's tank.

I believe you will agree that the most important single asset of al business is the good will of customers with whom business is trar acted. A company will stay in business only as long as the pub] wants to buy its products. In the petroleum industry good will ca be achieved by giving full and accurate measure on all sales of pro ucts which meet established specifications. In many other industri this can be effected with a minimum of effort because it consists mere of a physical count of packages of varying sizes. On the other han petroleum and its products are in such general demand througho the world that a rast measurement problem is produced. The rolun of petroleum and products transported and handled by the petroleu industry is tremendous. The vastness of the operation of the Indu try, the complexity of the measurement problem and, finally, tl ralue of crude oils and finished products all point to the fact th special care and attention must be given to measurements to insu accurate results. If these results are achiered, customers are assurt of full measure and essential loss controls can be maintained on $t]$ various phases of producing, manufacturing, transportation and ma keting of petroleum and its products.

The importance of accurate and careful gaging camnot be ore emphasized. 'The data secmred becomes the basis for' all future recort and calculations. If the original gaging figures are incorrect, it obvious that subsequent records, reports, or inroices will not balanc 
ile it may be possible to trace and correct inaccuracies in gaging, represents a costly, time-consuming procedure.

ou might well ask why the members of this Conference should be rested in this subject. Primarily, State and municipal sealers of ghts and measures participate in many important phases of meas$\mathrm{g}$ operations of the petroleum industry. In all probability, sealers ote more of their time to activities involving the gaging of petro$n$ and related products than to any other single commodity. In the ond place, one of the most important phases of the work done by National Bureau of Standards is the establishment of standards ch are used as the basis for measurements involving equipment 1 as calibrated containers, steel tapes, standard thermometers and er items used by the petroleum industry.

uring the early expansion of the petroleum industry, facilities for suring vast quantities of crude and products lagged in their develrent. As a result, many difficulties were experienced, some of which mately reached the consumer level. Not only was there a lack of formity and procedures from one company to another, but freatly this same difference was experienced in various phases of any company's operations. 'The inadequacy of measurement facilities ted a condition where accurate accounting for stocks and yields not possible. As a result, many oil companies realized that the plem merited special attention. In many cases this, in turn, led to formation of committees and departments within the company to dle this problem. These committees and departments were charged I duties the major purposes of which are the following: (1) Caliion of storage tanks and transportation media. (2) Design and truction of uniform gaging and sampling equipment. (3) Estabment of uniform procedures in the use of this equipment.

s early as 1898 the American Society for Testing Materials had formed, and the American Petroleum Institute was organized in

One of the important functions of these organizations is to nulgate codes establishing uniform procedures and equipment for accurate measuring of petroleum and its products. 'The exchange neasurement ideas and practices of the various segments of the istry is of benefit not only to the industry as a whole and the vidual parts thereof but also to the consuming public. This lange of ideas and practices has, under the sponsorship of the two ups mentioned, resulted in the issuance of the following codes ng many others: (1) API Gravity Tables. (2) ASTM Manual Ieasurement and Sampling of Petroleum and Its Products. (3) Code 25-Measuring, Sampling and Testing Crude Oils. (4) API 1201-Code for Non-Pressure Type Tank Car Quantities. API Code 1202-Code for Pressure Type Tank Car Quantities. API Code 1101-ASME-API Code for Petroleum Positive Disement Meters.

11 codes and manuals, whether issued in a tentative or final form, subjected to almost. constant review so that when revisions are ssary, the changes can be effected and all members of industry sed.

he basis for computing volumes of liquid quantities of petroleum its products is the incremental capacity table for the container. lved in any particular transaction. 'Therefore, before discussing' al measurement of petroleum, I would like to outline for you in neral way how the capacities of containers are determined. Ob- 
viously, capacity tables must be accurate; otherwise, all subsequ calculations of volumes handled will be incorrect.

Various methods, depending on the type of container being ce brated, are employed to determine the total and intermediate cap ities of the container. In my discussion today I will consider 1 strapping method as it applies to atmospheric tanks with fixed ror (also known as cone roof tanks) as this is the most common type tank in use today, builder's plan method as it applies to tank shi and the liquid calibration method as it applies to barges, tank cars a tank trucks.

Basic measurements are secured by the use of steel tapes of 11 foot or 400-foot lengths. These measurements consist of height the tank, its circumference at various levels, the thickness of st plates and, when necessary, measurement of "deadwood." "Des wood" is a term used to describe any construction detail inside of $t$ tank, the presence of which decreases its liquid capacity. After basic measurements are secured, tank capacity tables are prepar by determination of actual volume at the various heights measur and interpolation of circunference measurements where necessas If the tank is cylindrical in shape and if all cross-sectional areas : uniform, the calculations are relatively simple. 'They are based the standard formulas of the area of a circle and the volume of cylinder.

On tank ships, total capacities for each tank and the volume desired levels are secured by calculation of cubical contents bas on measurements from builder's plans. Consideration is given deadwood, such as pipe lines, ladders, bulkheads, etc., and the chang in incremental volume due to changes in the shape of tanks. It is interest how this is done. An engineering draftsman with conside able experience will study the builder's plan with an apprentice, as together they will make all the necessary calculations. This m: take from 3 to 6 months and the resultant calculations would app to similar vessels of the same class.

In the case of barges and tank cars, one popular method of dete mining capacities is the water calibration method. Quantities a loaded into the tanks from calibrated prover tanks. By stopping $t$ loading operation at desired intervals and computing the quantity ou turned from the loading tank, the rolume capacity can be determin at any level within the barge or tank car tank.

When tank trucks are first put into service, their capacities are detel mined by using a liquid (usually kerosene) measured from calibrat ) containers, the capacity of which has been certified. After the capaci of each tank has been determined. capacity markers are affixed in $t$ ] proper position and the full capacity shown on the dome collar.

In general, gaging procedures involve two separate steps. 'The fir' of these consists of actually measuring the product, and this m: be done by manual or automatic means. The second step consists . temperature taking, and this may also be done manually or aut matically.

In the actual gaging of most bulk-storage tanks, there are two ges erally accepted methods, namely, innage and outage. The sever modifications of each depend upon the type of tank to be gaged. A innage gage is the depth of liquid in a tank measured from the surfar of the liquid to the tank bottom or to a datum plate attached to the tar 
m. An outage gage (in the case of marine equipment, called e) is the measurement of the distance between the surface of the lict in the tank and the reference point, which is a fixed point or at or near the top of a tank. These measurements are used the tank-capacity table and temperature of the product to calcuhe rolume being measured.

general, measurements are secured by the use of calibrated steel of varying lengths in conjunction with calibrated plumb bobs. latter have pointed ends for taking innage gages and flat ends for $1 \mathrm{~g}$ outage gages. The tapes in use in the United States conform e tolerances and standards established by the National Bureau of dards. 'Tapes not meeting tolerances are withdrawn from service. 'hen an innage or outage gage is taken in a nonpressure container, ape and bob are lowered to prescribed levels, care being taken in ase of the innage gage to insure that the bob does not tip. On ge gages the measurement is read directly from the tape, while on ge gages the total reading is the sum of the tape and bob readings. e procedures for innage and outage gages are basic and are those generally. In other cases, however, special types of tankage respecial procedures and devices to measure their contents, for ple, the pressure lock for pressure tanks and the slip-tube gage for fied petroleum gas containers.

companies generally have made considerable progress in the lopment and acceptance of uniform gaging equipment and the lishment of uniform procedures in the use of this equipment. xample, difficulties were experienced in securing accurate measents of volatile products because of an uneven creep on the tape $b$, thus resulting in inflated measurements. To overcome this, a ine-level indicator paste was developed and is being used gentoday. Prior to the promulgation of standardization codes, urements were taken to the nearest 1/4 or 1/2 inch. The standoday is to the nearest $1 / 8$ inch, and in some companies, to the st $1 / 16$ inch. The need for and the advisability of accurate readto the nearest $1 / 16$ inch becomes evident when it is realized that $1 / 16$ inch in a tank 50 feet in diameter accounts for $77 \mathrm{gallons,} \mathrm{while}$ ank 140 feet in diameter the gallonage value of this measurement gallons.

the procedures in rogue and the standardization already aclished eliminate the possibility of inaccurate measurements? In the case of manual gaging, the human element is always presConsequently, oil company managements must constantly stress gagers the importance of the care to be exercised when gaging. me instances, flexible tank bottoms cause inaccurate measures. Every effort is made when constructing tankage to insure that ottom will remain firm and level. However, bottoms sometimes mder varying load conditions. In such cases, accuracy will be ly improved by maintaining a water bottom of such depth that it cover the entire bottom when flexed either up or down. This is in an effort to provide a level surface to measure the volume of or products involved. Difficulties are also experienced in securccurate measurement of the contents of floating roof tanks as the ne of product displaced by the roof is affected by friction between dge of the roof and the tank, by change of temperature due to ine, by wind, rain, snow, or ice, by settling time after pumping 
groduct into or from the tank and by partial suspension of the on its supports.

Gaging problems are considered as they arise and are subjer almost continual study. In some instances, these studies ins observance of the actual operation of tankage and facilities in field.

At the present time the use of automatic gages is being studie many oil companies. Many such devices are actually in use bu general, they are used only in comnection with morements of li quantities within a particular companr. Howerer, if mutually ag upon, they can be used in connection with morements between the panies concerned.

One such device which has been in use for some time is called sutomatic float gage and consists, in general. of a float gage atta 10 a. wire cable which, in turn, is attached to a completely encls (ounterweighted measming tape which registers image measmen and is usually read at ground level. Potential sources of error ir automatic float gage include change in the buorancy of the flos the gravity of the liquid changes, undue friction at sheares ground-reading pulley, and corrosion and distortion of the cable. the newer equipment these sources of error have to a large extent eliminated.

Another device actually weighs the tank contents and is spoke as a hydrostatic gage. This also has the distinct adrantage of viding the means of reading tank measurements. either at the of the tank or at some central point remote from the tanks themse This device generally uses dry air or gas to force the liquid tr gaged out of a rertical pipe within the tank. The pressure requ to force the liquid out of the pipe is registered through a gage out the tank or at a central gaging house br means of a gage filled a special, heavier-than-water liquid. 'This gage is calibrated on basis of Tater at standard temperature: therefore. all measurem are at that temperature. By knowing the exact specific gravit. the liquid being gaged. the reading of the gage can be conrertei exact feet and inches of the liquid at standard temperature.

Another item that must be considered in the determination of li rolumes of petroleum and its products is the temperature of the $t$ contents. Accurate temperature readings are essential as they $f$ the basis for conversion to $60^{\circ} \mathrm{F}$ of quantities involved on interc pany transactions and also provide an important phase of adequ stock control.

Usually only one temperature reading is taken at the rertical ce] of the product, although in some cases it mar be necessary to sec. more readings, as specified by API and ASTII codes on this subjt

When taking themometer readings. care must be taken to ins that the thermometer has been immersed in the liquid for a per sufficiently long to attain the temperature of the liquid. Also, w withdrawing the thermometer from the tank, care must be taken aroid change in the thermometer indication, which may easily caused by atmospheric temperature or wind blowing across the lig contained in the cup at the base of the thermometer. This effect be ninimized by sheltering the thermometer cup within the gage 1 while reading the thermoneter to the nearest degree.

The accuracy tolerance for thermometers, previously plus or mi: 1 deg F, has lecently been changed to plus or minus $1 / 2$ deg F 
noneters used for gaging purposes. Studies of tanks in operat hare revealed that different temperatures prevail at different This is especially true on tanks containing riscous materials oducts that must be heated to expedite their flom. Partially as ult of the foregoing, oil companies are turning their attention to ccuracy that might be secured by the use of automatic devices h provide the means of securing mechanically arerage temperaof tank contents. In most instances, the temperature readings e taken at some central point remote from the tanks themselres. sts of one of these derices have indicated that it has a high order curacy. This derice is known as an electrical resistance thereter. Which measures the increase or decrease in electrical resistin a fine copper wire caused by any change in temperature and ters the results of these measurements on a temperatme indicator: derice will operate satisfactorily when nsed in connection with - containing heated or unheated products.

te whole subject of measuring and allied operations is in a state ontinual study, so that the latest arailable procedures can be ap- and the accuracy and practicability of derices can be determined lecisions made as to their installation and acceptance by industry neral.

you are aware, meters used for the dispensing of liquids are an ritant phase of petroleum measurements. 'The first meter's used converted water meters which were accurate to about plus or is 2 percent. The introduction of displacement meters and cond experiment and derelopment have brought greater perfection. - macies now obtainable are quite remarkable. The derelopment of ter accuracy in measurements has made it possible to meet the nt tolerances required by the rarious state regulatory bodies. ter meters have been properly installed, by far the most important requirement for proper operation, regardless of the trpe of - used. is meter proving and calibrating as frequently as necessary. is important because not only must the oil company ascertain that uners of their products receire accurate measure on delireries, t must also take reasonable precautions against overloading or lelireries. To achiere the desired results, oil companies generally tain proring equipment on mobile trucks that is of adequate size oth loading rack meters and tank-truck meters. In most instances. neter manufacturers are also equipped with mobile calibrated r equipment.

e basic requirements for good performance in all meter installaare that the installation shall be (1) Capable of and aclapted for ate meter proving. (2) Conducire to the elimination of air apors that might become trapped or induced ahead of the meter. Provided with a suitable means of segregating dirt, scale, foreign cles. and water from the measured stream. (4) Such that ideny the same phrsical conditions of equipment. liquid and operating icteristics can be maintained for the meters during their proving ill exist while they are later operating normally on the metered $\mathrm{m}$.

e use of meters has tremendously increased in recent rears. This rticularly true of meters nsed on loading racks, pipelines, and trucks dispensing household heating oil. As the trend is torard er increase in the use of meters, it becomes essential and most 
important that the degree of accuracy required by the reights measures anthorities be maintained at all times.

I have previously mentioned that a code has been issued through joint efforts of the American Society of Mechanical Engineers the Imerican Petroleum Institute on positive displacement me This code, which is further evidence of the active interest in this ject, provides a suitable basis for the installation, proving and op tion of positive displacement meters suitable for measuring lic hydrocarbons to be purchased, sold, or exchanged in the petrol: industry or elsewhere. The provisions are deemed applicable to $\mathrm{p}$ tically all such installations. However, with respect to meters for the measurement of retail sales, the provisions of rarious $S$ weights and measures regulations govern and shall take precedf over this code. On one major pipeline in the South, the use of me for measuring the flow of petroleum products has become indisper ble. This pipeline transfers sereral petroleum products and ses different oil companies. When any new product is sent through line, as, for example, kerosene, the meters are recalibrated, the calil tion taking the form of a factor that is applied to the meter read:

Under certain conditions, the meters may be recalibrated as quently as twice a day. Because a meter as large as the pipeline would be uneconomical and difficult to handle, there may be three four 6 -inch meters in parallel on an 8 -inch line. thus providing the 1 : essary flexibility in operation.

The measurement of petroleum presents a serious problem to industry. The complexity of this problem, increased by the need numerous, accurate measurements, is not generally known by the $c$ sumers of petroleum products. Oil companies and manufacturer's engaged in continual research so that the most accurate procedu equipment, and derices can be applied in the measurement of pet leum. Ultimately, a large share of these measurements will undor edly be obtained by automatic or semiantomatic means.

The work of the sealers in the oil industry, which for the ma part consists of checking the capacities of various types of transp tation media, the calibration of dispensing equipment, and the est lishment of accuracy tolerances for this dispensing equipment. had an important influence on the derelopment of accurate measu ment. Their activities serve the dual purpose of assuring the consum that full measure is received and of assuring the dispenser of the $\mathrm{pr}^{*}$ uct that an equitable compensation is secured for the quantit handled and sold.

\section{GRAIN WEIGHING}

Br DArid LuxDeEx, State Wrighmaster. Track and Hopper. Scale Departm State of IImnesota: President National Scale IIen's Issociation

Is this rear's president of the Tational Scale Men's Associatic I deem it a great honor to represent our spendid organization at $\mathrm{t}$ ] Conference, and I wish to talie this opportunity to greet rou on behi of our membership. Our annual Convention at Chicaso last Mar was one of the finest and most instructive meetings ever held by o group. I feel, as I am sure all members of the National Scale Mes? Association feel, that we should work rely closely with the Nation. Bureau of Standards and representatives of weights and measur departments in matters relating to scales, in which we all have a col 
interest. As far as scales are concerned. we have the same goalscales, resulting in more accurate weights.

rain weighing" is, without a doubt, one of the most important hing functions in the country. Many farmers weigh their grain eir own scales before taking it to the local market. It the local tor it is reighed when the producer sells the grain. It is usually hed by the local elevator when the grain is shipped to the terminal ets, and at the terminal markets it is weighed on arrival, as well nen shipped out. Millions of bushels of grain are weighed within lerator itself as the grain is transferred from one bin to another. total amount of grain that is weighed in this country and the of the grain are probably impossible to estimate accurately, but safe to say that it runs into billions of bushels and billions of rs.

the Minnesota Grain Teighing Department, we weigh approxiIy $500,000.000$ bushels of grain anmually. About $300.000,000$ els of this grain are weighed in and out of boxcars. Approxily $175,000,000$ bushels of grain are weighed into boats at Duluth, gned to points on the Great Lakes and onto barges on the MissisRiver at Minneapolis and St. Paul to points south. The balance in weighed in truck-load lots and in transfers within the terminal tor itself. You will note the tremendous amount of grain that ighed into boats, most of which emanates from Duluth.

ir people, living in other parts of the country, realize that, from andpoint of tonnage handled, the Duluth-Superior port is second to New York.

might also be interesting for you to know that the largest aggre, $n$ of grain elevators in any one city in the world is in Minnes, where some 65 elerators have a total storage capacity in excess $, 000,000$ bushels.

e Mimnesota Grain Inspection and Weighing Departments were lished in 1885 by the Minnesota State Legislature, by a la w passed e fifth of March of that rear. Under that law operations comed on the first of August 1885. This law provides for the inspecf grain and the weighing of grain as it arrives and leares terminal tors. The State being rather roung at that time, only three were designated by the Legislative Act as Terminal Grain MarThey were Minneapolis, St. Paul, and Duluth. The law, howgare authority to the Railroad and Trarehouse Commission, - which these departments function, to designate other points erminal Markets. At the present time, we have State grain hing at ten markets.

might be interesting to know that this was the first grain departof its kind, established in the United States, where inspection reighing of grain was under State jurisdiction.

ter the department was established. grain weighing was pered by Minnesota State weighers, not only in Mimnesota, but in onsin, Iowa, North Dakota, South Dakota, and as far west as land, Oregon. Since that time, most of these States have estabd their own grain inspection and weighing departments, and the hesota department now only functions within the boundaries of State.

e first testing of scales in the State was by "Scale Experts," as were called in those days, who worked under the supervision of itate Weighmaster, who is in charge of grain weighing. The 
first so-called "Scale Expert," who now would be called a "Scal spector," was a man by the name of L. D. Berry. He was appo to this position shortly after the department began to function. rommenced testing scales, over which grain was weighed, in terr elevators, early in 1889. Later, he was given an assistant, with $\pi$ a great many of you are acquainted, and who has been for orer a century one of the leader's in weights and measures work in country. I refer to none other than the venerable C. C. Nea Minnesota man of whom we are very proud. Mr. Neale worked u the State Weighmaster until the Weights and Measures Depart was established in 1911, at which time he was appointed the Commissioner of Weights and Measures in Minnesota. The scal spectors, howerer, who tested the scales on which grain and it products were weighed remained under the supervision of the s Wreighmaster.

'To put it differently, the Weights and Measures Department in State of Minnesota has supervision over all scales and measu devices, except railroad track scales and the other scales over $\mathrm{w}$ grain, its by-products, hay, straw, and coal are weighed, and on w commodities the State Grain Weighing Department issues certific of weight to the trade. These scales are mnder the jurisdiction of State Weighmaster. This is a common practice at most large tern markets. The advantages of such an arrangement are well recogn and too obvious to require comment.

Tre have, in Minnesota, approximately 85 State grain weighing tions and an average of 130 State Grain Weighers. At the term elevators we have both hopper and track scales. It some eleva we have both. 'The hopper' scales are tested with 8,000 pound. known weights and, on the step-up test, to the capacity of the hop The tolerance on hopper scales is 1/4 pound per 1,000 pounds.

The State of Minnesota has two State-owned Master Scales. of these scales has a 12-foot weigh-rail and the other a 34-foot wr rail. These Master Scales are tested each year by the National Bur of Standards. This is a service of real ralue for which we are 1 grateful. As far as I know, these are the only Master Scales owner any one State in the Union. Our Master Scales are the only one the northern section of the conntry between Clearing, Illinois, Portland, Oregon.

On our track scales, not used for grain weighing, we maintai tolerance of one pound per 1.000 pounds and, on track scales used weighing grain, a tolerance of 1 o pound per 1.000 pormds.

Wre have four railroad test cars, ownerl and operated by the St Two of these cars have a 20 -foot wheel-base, one calibrated at 82. pounds and the other at 90,000 pormds. We also have two $7-1$ wheel-base test cars, each calibrated at 80,000 pounds. Tre make ev effort to have these test cars calibrated once erery month. It peric intervals we test all the raihroad track seales with both of the st. wheel-base test cars, testing at 160,000 pounds.

Tre have six scale inspectors in the department. Two inspect are constantly on the road with the railroad test cars. Three spector's work in Minneapolis, St. Paul, and suburbs. In Minneap" we maintain a laboratory which is used by both the Weights Measures Department and the Track and Hopper Scale Departme Here we calibrate comterpoise weights and 50-pound test weig- 
nspector is assigned to testing hopper scales in Duluth, where the ptment also maintains a laboratory.

test all track and hopper scales twice a year, and occasionally often. When a scale is taken ont of service for repairs, it is ted before being put back into service.

the master scales we calibrate our own railroad test cars and also ailroad-owned test cars used in our part of the country.

$r$ railroad-track-scale test cars are moved by the railroads, free large, to whatever points we bill them. This free service is latorr, under the law.

have 228 hopper scales at terminal elevators and 177 railroad scales, of which 64 are State reight track scales. When hopper or track scales are used for the purpose of reighing grain, State weights are taken, the cost of the test is absorbed in the weighing fee. Otherwise, there is a $\$ 10.00$ charge for a railroad-scale test and a $\$ 15.00$ charge for a hopper-scale test.

the fiscal year 1951 we made 361 railroad-track-scale tests and opper-scale tests. We effected 41 railroad-test-car standardizaand calibrated 729 counterpoise weights, 1,38550 -pound test hts, and 28 slings. During this year we found 60 track scales and pper scales out of tolerance.

should be noted, in this connection, that our scale inspectors do nake any scale repairs. Howerer, if a scale is found out of ance and adjustments can be made during the test by the inspector ing the scale within tolerance, that is done.

Iy recently, new specifications were adopted by the Railroad and ehouse Commission, which provide that new railroad track scales lled in Minnesota shall have a minimum capacity of 75 tons ection.

Itween the semiannual tests of the track and hopper scales, the inors are constantly making inspections of the scales used in the hing of grain. The objective. from the beginning, has been to re good scales, properly installed and maintained, regularly cted and tested, so that both the buyer and seller of grain can nfident that ther are receiving accurate weights.

track scale or State reight hopper or motor-truck scale may be lled in our State until the plans for the scale and plans for the llation have been submitted to our department and approred, o railroad track scale may be removed unless application is first to the Railroad and Warehouse Commission and such application oved.

freight charges on grain cars are fixed on the basis of the hts taken by the State weighers at the various terminal elevators. en a car of grain is weighed, the car number, car initial, capacity car, seals on the car, and any leaky or bad order conditions of ar are all noted in weight and seal record books which are kept State weighers at the elevators. In addition to this, the weigher s out scale tickets, which are filed in the office of the Weighing rtment.

e weigher also makes a daily report, in triplicate, one copy of $\mathrm{h}$ is available, in the Treighing Department office, to the grain and the railroads. From these reports, as well as from the scale ts, the railroads take the weights on the cars on which they deterthe freight charges. In our office, all reports of the weighers are gated and posted, according to elerators, so that, if the grain 
trade or the railroads desire to check the cars weighed at a parti elevator, they need not be concerned with any other reports. the original copy of the reports, certificates of weight are typec filed in a Post Office box maintained in the office for each grain

It is obvious that business transactions, involving millions of do transpire every day on the basis of these weight certificates; and the basis of all this somewhat complicated procedure is the good properly installed and maintained, tested by the scale inspectors properly handled by the State weigher, under the supervision o State Wंeighmaster.

Minnesota was, as already noted, the pioneer in establishing a : Grain Weighing Department. Not only was Minnesota the first in the Union to step into this picture, but we frankly believe Mimnesota is today a leader, if not the leader, in the matter of acc weights in the weighing of one of the country's important commod namely, grain.

It might be of interest to you, gentlemen, to know that the de ment is self-sustaining and always has been since it began operat I fee is charged for the weighing of each car. 'The fee, at the pri time, is $\$ 2.25$ for each car and $\$ 1.00$ for each truck, and $\$ 1.25$ for e 1,000 bushels weighed into a boat or transferred in the elevator. total fees taken in by the whole Grain Department rary from ye: year, but for the fiscal year 1951-52 will exceed $\$ 1,500,000$. The we ing fees alone for this particular year will exceed $\$ 700,000$ and leave a substantial surplus at the end of the fiscal year.

This department, from its inception. has been under the jurisdic of the Minnesota Railroad and Warehouse Commission, consistin three elective commissioners.

I trust that the information I have given you may be of some int and value. I have deliberately given you considerable detail as te grain-weighing functions of our department. If any additiona formation is desired, I shall be glad to furnish it.

I feel and always have felt that all of us, who are in govern service, whether it be on the local level or in State or Federal ser have a duty and responsibility to perform our work in such a mas that we are a credit to the government for which we work and a benefit to the citizens we serve.

\section{RAILWAY TRACK SCALE TESTING PROGRAM}

Bч J. N. ToDd, Superintendent, Scales and Tork Equipment, Southern liai System, Wrashington, D. C.

I am very grateful for the opportunity to speak to you from standpoint of the railroads on the subject of railway track scale 1 ing. While I cannot say that I am speaking for the Association American Railroads, because they have not been asked to give expression of their views, I am quite certain that they will be ples by any move to better relations between the railroads, the Natic Bureau of Standards, and those agencies in the States concerned $r$ weights and measures.

My subject is related principally to the program of testing car out by the National Burean of Standards, and it seems most apl priate to speak of it at a time when there is such a representat gathering of weights and measures officials from throughout country. I would like to speak not only of the program as it exists 1 . 
a little of its history, but also of its future. There is, in my hion, no reason to be concerned about the future of such a beneficial, a a necessary, activity, but it is important to keep all of you innerl of its function in trarle and commerce; particularly those of from States where divisions of weights and measures have been up or expanded in recent years. 'Iherefore, its future is something you should know about as you may have a part in it yourself, ther or not you actually do any testing.

is not intended at this time to make any predictions of things ome nor to imply that you will be brought into the actual testing rack scales, because I know nothing of such a possibility. I do w that, with the increased interest of the State agencies in all 1 matters, it is well for us to consider how such an interest in track e testing may be served best. At this time, there are only two -es in the country, where track scale testing is carried on with pment other than that of either the railroads or the National ear of Standards. 'There are special reasons for these agencies they require the calibration services of the Bureau. Before we nto the Bureau activities any further, let us see how the railroads nto the picture, and then we can better show how necessary is 'Bureau's place in this most worthy enterprise.

he railroad industry is one in which scales of large capacity have hed their widest use. It is estimated that there are nearly 7,000 $\mathrm{k}$ scales in the country counting both those owned by the railroads by the industries. Ten to fifteen percent of these were tested ually for many years by the National Bureau of Standards in its ple testing. This will be discussed later. The railroad industry bout a century and a quarter old, and the use of track scales came 1 after the beginning of the railroads. One of the great forward s in the field of weighing came about that time, when the Fairks brothers brought out their famous platform scale. I am almost e, from what I have seen, and I believe the scale men of the Bureau l agree, there must be some of those original scales still in use. speaking seriously, we do have the extremes of good and bad on railroads. Usually, however, the small and obsolete scales are in only where the service is light.

"he present-day test procedure is not very different from that foled more than half a century ago. At that time a special car was d up and assigned for testing scales only. Today we have solidy test cars for the same purpose weighing from 30,000 to 100,000 nds each. Test reports showing the results of testing 50 years are quite similar in many cases to those in use today, but the racy of the scales then and now makes a different story. By present standards most of the scales 50 years ago would have been of tolerance. It is reported that on one railroad a scale was ,roved if the error did not exceed 400 pounds, regardless of the load. It was about that time that the National Bureau of Stand$\mathrm{s}$ was engaged in tests and inspections of scales of less than 10,000nd eapacity. The frequency and magnitude of errors found in es of that.category led to the belief that scales of greater capacity ald have similar errors, and of magnitude in proportion to their acity. The sequel to that was for the Bureau men to follow raild testing of larger capacity scales, and, not having test equipment heir own, to observe the results and to inspect the scales. 
Many and large errors did occur and as a consequence of these servations congressional approval was obtained for equipping Bureau personnel so that actual testing of track scales could be ried out by them. The first test equipment of the Bureau was c pleted in 1913, and before the end of that year 38 track scales 1 tested in four eastern States, in a sort of practice run. The res of these tests were startling, and, to show just how bad condit were, the following is quoted in part from the annual report for fiscal year ending June 30, 1914. The mention of any particr State here is no reflection on it, as subsequent testing throughout country revealed conditions equally bad elsewhere.

Allowing for a tolerance of 0.2 of one percent, which in the opinion of $t$ Bureau, is a fair tolerance for such scales, so percent of the 16 scales test in Vermont would have been rejected; on a tolerance of 0.4 of one perces 60 percent would have been rejected; and on a tolerance of 1.0 percer to percent would have been rejected.... Of the 16 scales tested at $t$ port of New York, 75 percent would have been rejected on a tolerance 0.2 of one percent, 56 percent on a tolerance of $0 . t$ of one percent, and percent on a tolerance of one percent.

The abore results clearly show the necessity for periodic inspection such scales and indicate to some extent the great losses which may be su tained by the use of uninspected scales. As previously pointed out. tl inspection of railroad track scales . . . should be taken up by or under tl supervision of the Federal Gorernment . . . for the reason that practical all shipments weighed upon them are interstate.

A second test car was secured soon after this time. During the lowing fiscal year, with only the original unit in operation, a sched of tests orer a widely distributed area was arranged for the purp of obtaining the first overall picture of conditions. The Bureau 1 adopted a tolerance of 0.2 of 1 percent, and of the 338 track sce tested during the fiscal year 1915,68 percent failed to pass. It mi; be stated that during the succeeding 25 years of Bureau testing. percentage of track scales passing required tolerance rose from abr 32 percent to about 85 percent.

The conditions found during the first year of testing were report to the American Railway Association, now the Association of Ame can Railroads. which entered into discussion with the Bureau leadi to an agreement providing for an expansion of the Bureau's activiti In recognition of the benefits accruing to the carriers, the agreeme provided for the free transportation of the Bureau test cars. La on, two standard type test cars of 40.000- and 80.000-pound capac were added and during the years that followed. frequently more th a thousand scales were tested per annum. In addition, all mast scales were calibrated on approximately an annual basis.

In general, this procedure was followed for many years without a great variation, until the second World War, when activities were $\mathrm{ct}$ tailed for several reasons. First, the two standard test cars of 40.00 and 80,000-pound capacity were disposed of because it was felt that $t$ purpose for which they were bought had been served. Also, the sho] age of personnel and the obsolescence of one of the original testi: units further reduced the extent of the testing activities. While ste have been taken to improve conditions in some ways, the service $h$ not yet returned to anything like that existing prior to the last Wor War.

It might be well to explain briefly here what the practices are, wi respect to the testing proceslure of the National Bureau of Standar 
how the anmual schedule is arranged. The main purpose of the eau's work with railroad track scales is to calibrate the 19 master. $k$ scales of the country annually, insofar as possible. 'The second and of almost equal importance to the first, is to calibrate indiral test cars in those areas where master scales are not easily avail-

Unfortunately, there are two large areas in the country without er scales, and there are some railroads in other areas which own cars but find it difficult to send them to a master scale. In both of e cases test cars are calibrated by the Bureau as well as can be done. $\mathrm{g}$ the best track scale arailable. The least important activity, but that serves a good purpose, is sample testing of track scales. In anging the schedule each year, an effort is made to select those scalerecently tested so as to get a broader picture of scale conditions erally. The way is left open, however, for special requests. The schedule when prepared is submitted to the Association of rerican Railroads, and by it to the member roads involver. Sone nges are usually made, and when approved, copies of the schedule distributed to all concerned. Then the Bureau's test units start on their circuitous routes to cover the countrr. Points of internge between railroads are indicated on the schedule and each road otified when the equipment is approaching its point of connection. lally a railroad representative is present at all tests, and should. hout fail, be present at the calibration of a master scale.

The same statement of purpose that I have given above in my own guage may be stated more concisely and authoritatively by quoting following paragraph from one of the Bureau's annual reports of ck-scale testing:

The National Burean of Standards fnnctions as an agency of the United tates Department of Commerce. Two of its fundamental responsibilities re to provide industry and commerce with authentic weighing and measIg standards and to pursue such measures as are helpful in assuring that il weighing and measuring operations essential to trade and transportaon are performed on a uniform basis and with acceptable accuracy. The - tilway track scale testing service is the instrumentality through which re Bureau fulfills these important responsibilities to the rail transportaon industry and to interstate commerce where the wholesale marketing nd distribution of materials are conducted in terms of carload weight nd involve the utilization of several thousand railway track scales.

Chat, in my opinion, is an excellent statement of the high purpose which the railway track scale testing service was originally tituted.

Fow that we have seen the equipment on its way. let us follow it "a master scale. All master scales are quite similar although of ferent makes and models. Usually they are housed in heated and fitilated buildings in order to have the most uniform and farorable iditions under which to seal cars and to calibrate the scale. It is ortant also. to the Bureau representative, to have such conditions, the job of calibration is a tedious one and one requiring great e. Sometimes, when adjustments are required. the calibration reres as much as three dars. The scale platform is msually 12 feet $\stackrel{x}{ }$, and the scale has a sensitive weighbeam, with $21 / 2$-pound gradions generally. The master scale has a capacity, usually, of 100,000 inds.

The equipment used by the Bureau is in a large car similar to a troad baggage car and consists principally of a generator set, an ctric overhead crane, and a set of 10.000-pound weights totaling 
80,000 pounds. 'This includes an electrically driven test truck, wl with an added weight, equals one 10,000 -pound unit. The o weights are placed on the test truck, and the test load is movec rarious positions on the weighrails. The car has end doors and crane can be extended beyond the doors so as to transfer weis from the interior of the car to the scale platform.

Ordinarily the calibration of a master scale comprises three st rate tests, each being conducted with mass standards of high ? cision. The first phase is called a maintenance test and is to de mine whether the required qualities of performance have been m: tained since the preceding calibration. For this test, standa weight loads of $40,000,60,000$, and 80,000 pounds are applied to scale, in two successive test runs, at each of five positions on the si rails. If any adjustments or other modifications are necessary, scale is then given an adjustment test. In this case, the loads ra from 30,000 to 80,000 pounds by 10,000 -pound increments, the cedure being the same as before. If no adjustments or modificati are necessary, the maintenance and adjustment tests are combin The tolerance for the adjustment test is one-half that of the ma tenance test, and runs from 3.7 pounds at 30,000 pounds to 6 pour at 80,000 pounds. To show how accurate a master scale is, the 6-por tolerance at 80,000 pounds is comparable to a 160 -pound tolera under the same load on an ordinary scale. The third phase of c: bration consists in testing the counterpoise weights.

Most of the class one railroads perform their testing with their o test cars, the weighing being supervised by weighing and inspecti bureaus representing all the railroads of an area or region. 'The sa bureaus supervise weights from private scales along the line, a these scales are tested by the railroad, usually on a free basis, if t weights are used for revenue billing. Such scales are covered weight agreements and weights may be used only so long as the sc: is kept in good weighing condition. The test car's thus used are seal on master scales calibrated by the National Bureau of Standar In this way, the standards of mass are transmitted to industry a commerce throughout the areas served by the railroads.

From these facts you can readily see how important is the servit: rendered by the National Bureau of Standards to interstate cos merce. It is, in my opinion, one of the greatest services national in the field of weights and measures. But it has not recovered frc the letdown of the second WVorld TVar, and the condition of our tra. scales reflects that letdown. The percentage of scales found accura bears an inverse ratio to the volume of testing by the Bureau. $\mathrm{T}$, results last published by the Bureau showed a definite drop in $t$ ? curve following the curtailed service. Railroad officials have alrear expressed themselves to the Bureau as favoring a return to a high standard of service. Many faror a return to the full service rendert prior to the last World War.

Another matter that would be of help to the program of testing one that presents a problem not easy of solution. That is the nee for Master scales in two important areas of the country. One of tl areas comprises all of the New England States plus New York anNew Jersey. The other area includes Texas and its neighborin States.

May I say to you gentlemen that your interest in this matter the public interest. It may be true that you, as representatives $c$ 
c weights and measures departments, do not take active part in ng railroad track scales. But you should be informed on the ect and my efforts today have been directed toward that end. are the authority on the subject of weighing in your juristicand some day you may be called on for information. You are ted to come and observe the calibration of our master scales, and testing of our track scales. May your knowledge grow and may find occasion to help in this worthy enterprise.

uring the third session of the Conference three guests representing the nal Bureau of Standards were presented. Dr. Lyman J. Briggs, Past dent, National Conference on Weights and Measures, and Director EmerNational Bureau of Standards, greeted the delegates and made a few exoraneous remarks regarding the progress of weights and measures adstration in the United States.

Wilmer Souder, Consultant Physicist, National Bureau of Standards, ioned a recent survey in Costa Rica which he had made at the request of . S. Department of State to study the problems of standards and training will fill their exact needs.

A. T. McPherson, Associate Director, National Bureau of Standards, who -tly supervises the activities of the Office of Weights and Measures, was ented to the Conference and spoke briefly.

he conference was adjourned, to reconvene at 10:00 a. m., Thursday. May 952$.

Jn the erening of Wednesday, May 21, an informal party was held at the dman Park Hotel, the Conference headquarters, for those attending the ierence.)

\section{URTH SESSION-MORNING OF THURSDAY, MAY 22, 1952}

(Erling Hansen, Vice President, presiding)

\section{REPORT OF THE COMMITTEE ON WEIGHTS AND MEASURES EDUGATION; PRESENTED BY CHARLES MORRIS FULLER, CHAIRMAN}

'he formidable obstacle that confronts too many weights and measofficials is lack of sufticient manpower and equipment to do a ough job. This is not only disheartening to the conscientious ial, but it is most unfair to the people of his jurisdiction who are rented from receiving the protection to which they are entitled. miserly attitude toward departments of weights and measures is e economy-another example of "penny wise and pound foolish"; money expended on this kind of law enforcement is a dividending investment, saving the taxpayer many times its cost.

ifficial recognition was given this problem 2 vears ago at the 3ith ional Conference, when your Committee on VI'eights and Measures ication was directed to make a study on budgetary procedmes. object of the study was to establish a yardstick, based on indisable facts and figures, that could be used in support of bulget lests for legitimate needs.

Jur first undertaking was to accumulate a large fund of relerant inmation. This was accomplished by corresponding with 127 oflls, representative of both large and small departments, and located all sections of the country. 'They supplied the answers to our stions concerning personnel, equipment, and what they estimated needed in order to thoroughly cover their respective territories. he genuine interest and spirit of cooperation on the part of those tacted was proof that here was a subject close to their hearts. It 
gave an added incentive to our efforts to produce a comprehens report of practical value.

Last vear, the first portion of the report was ready for the 36th : tional Conference. All pertinent facts, comprising over 800 ites were tabulated and the charts presented, together with an explanat of the same and a review of the work to date.

Since that time, an intensive study has been made of those statist and opinions. Your Committee has prepared a number of reco mendations for your consideration. In arriving at these conclusio we have had the valued assistance of $\mathrm{IV}$. S. Bussey, Ralph IV. Smi and a considerable number of leading oflicials. Te express our sinct thanks to them.

In considering the matter of personnel, I think that we will agree that weights and measmes should be a full-time job. A lot harm has been done in some sections where an inspector or sealer appointed in every little town. It is merely considered as a ve small political plum. The salary does not amount to much, and lit or no work of real value is done. The general public in those plac has a pretty low opinion of weights and measures. A number these comminities should join together and maintain one efficient $c$ partment that would function throughout the year, or the work shou be done by the State.

'There are certain factors that must be considered in estimating $t$ personmel needed for any particular district. In area that is heavi industrialized will require more time and effort than one that is most rural. Therefore, any numbers arrived at, based on average requir ments, will be subject to some degree of modification.

In general, one inspector should be allotted for each 50,000 popul tion or major fraction thereof.

The official in a small jurisdiction who carries on by himself neer to make some arrangement by which the public can contact him. 'Th can be provided by setting a certain time each day for taking care ( his office work, when he would also be available for visitors and tel phone calls. When he is in the field, calls could be transferred to neighboring office, where a memorandum would be made of the nam and numbers for his attention on returning.

Considerable thought has been given concerning economies in oper: tion that can be effected in the larger departments. Although this: true so far as the routine inspection work is considered, we must recos nize the fact that there are also heavier responsibilities. The larg department will usually maintain equipment for testing motor-truc scales and large-capacity meter's. The State generally handles thi work for the small departments that camnot justify the expenditur for their limited operation. 'There is also a greater ratio of con' Jaints to investigate and prosecutions to institute in the large cities ITe feel that the general formula as stated above should be used.

While on the subject of personnel, we might well enumerate serera principles that have much to do with the successful operation of : weiglits and measures department.

The members of the organization should be under some form of civi service and not be dependent npon politics, either at the time of ap pointment or for tenure in oflice. You cannot give fair, impartial en forcement of law and regulations if you are controlled by politica influence. Neither can you have eflicient inspection service in a highly 
hnical work if trained and experienced men are going to be sacrid. every time there is a change of administration.

The chief and his staff should devote their entire time and energies weights and measures, and not be burdened with other duties. ey should also function as an independent unit of government and be under the direction of a superior whose main interest and apathies are with some other activity.

falaries at the present time, in far too many places, are less than "prevailing wage" for other positions whose responsibilities and ies can be considered in the same rank. This must be remedied. u will not attract the desired type of men, who will stay with this rice for a career, if they are underpaid. Competition, today, is too 11.

The question of salary range is one that deserves, and has received, reat deal of careful study. The step-advancement plan, which vides for annual increases in salary over a period of years, has nonstrated its worth as an incentive for continuous service. Proion for several grades of employees in the larger departments, the cher grades being filled from the lower ranks by promotional examtions, acts to encourage the ambitious man who is striving at all res to do a better than average job.

Here is how one of the larger departments is set up. The entire ranization is under civil service. Entrance is at the lowest grade ere the men work under close supervision. They may drive one the heavy-duty weight trucks and handle the weights for the senior suty in charge; or they may assist in large-capacity meter tests. e important thing is that, while they are assigned to the heaviest, ighest part of the job, they are also given an opportunity to learn. might be called a trainee period.

When there is a vacancy in the next or intermediate grade, a protional examination is held, and the trainee has a chance to step up that position. He is still under the supervision of a senior deputy, $t$ is doing such work as assisting in the testing of scales in retail res and markets, or gasoline pumps in service stations.

Then, when there is an opening for a senior deputy, this is filled a promotional examination open to deputies in the lower ranks. st of the positions are in this classification. 'They are trained, perienced men who are capable of handling any situation that may se in the field.

There are also two complaint deputies who work with women ppping investigators, following up complaints about short weight measure, securing evidence, and prosecuting violators in court. The department is divided into two sections one being scales and ights, and the other, gasoline and liquid-measuring devices. Each under direction of an assistant.

A five-step salary schedule is in operation. The employee receives base salary on entering each position. This is automatically inzased every year until the top of the grade, the fifth step, is reached. some places, a six-step plan is used; others have three or four.

In studying the salary situation, your Committee has made a survey salaries paid in governmental positions of comparable duties and sponsibilities. It has also been mindful of wages paid by industry. 'The following are recommended as minimum anounts to be paid ien first entering that grade of work, with automatic increases 
to take place at the completion of each year of satisfactory se until the maximum is reached. By "minimum amounts." we I that no salaries should be less than those stated. There will unde edly be some places where, owing to living conditions or other siderations, entrance salaries will be higher. As a rule, there spread of 20 or 25 percent between entrance salaries on the first and those on the last step.

\begin{tabular}{|c|c|}
\hline Personnel & $\begin{array}{l}\text { Minimum en- } \\
\text { trance salary } \\
\text { a month }\end{array}$ \\
\hline \multicolumn{2}{|c|}{ Departments ( 20 or more employees) } \\
\hline $\begin{array}{l}\text { Trainees } \\
\text { Intermediates } \\
\text { Senior deputies } \\
\text { Chicf deputy } \\
\text { Department head }\end{array}$ & $\begin{array}{r}\$ 250 \\
275 \\
320 \\
\text { a } 450 \text { to } 550 \\
\text { a } 500 \text { to } 650\end{array}$ \\
\hline \multicolumn{2}{|c|}{ Departments (10 to 19 employees) } \\
\hline $\begin{array}{l}\text { Deputies } \\
\text { Chief deputy } \\
\text { Department head }\end{array}$ & $\begin{array}{l}\$ 250 \text { to } \$ 320 \\
\text { a } 400 \text { to } 445 \\
\text { a } 500 \text { to } 545\end{array}$ \\
\hline \multicolumn{2}{|c|}{ Departments (less than 10 employees) } \\
\hline $\begin{array}{l}\text { Deputies } \\
\text { Chief deputy } \\
\text { Department head }\end{array}$ & $\begin{array}{l}\$ 250 \text { to } \$ 320 \\
\text { a } 350 \text { to } 395 \\
\text { a } 400 \text { to } 495\end{array}$ \\
\hline \multicolumn{2}{|l|}{ Departments (1 man) } \\
\hline Sealer or inspector & $\$ 300$ to $\$ 350$ \\
\hline
\end{tabular}

a Depending on size of department.

We believe that the above recommendations are equitable and line with present prevailing wages for comparable positions. ' $\mathrm{Tl}$ should enable us to recruit men of excellent caliber for this valua service.

The subject of standards and equipment is thoroughly handled National Bureau of Standards Handbook 26 (chapter 14 and appe dix III). No better guide can be found.

A station wagon will provide good transportation for all-arou inspection work, especially for the small department.

Expenditures for maintenance and operation will vary great according to the nature of the jurisdiction-industrial or rural, co centrated or scattered, occupving a small or large area. Thus, find one department, in a compact area, where the maintenance ar operation will be only 12 percent of the salary budget. Anoth department, operating over wide stretches of territory, will requi as much as 30 percent. The percentage for State departments usually greater on account of nore travel expense. No set formu can be established. Provision should be made to fully take care the actual expense of operating sufficient equipment to enable tl personnel to cover the work of the juristiction.

Capital outlay, of course, will depend upon the needs of a pa ticular department. It will be large for the department that is ju 
ting a start and needs almost everything; small for the departnt that is well established and requires mostly replacements of work nipment. Every effort should be made to keep abreast with the gress of industry by acquiring the type of inspection equipment it will take care of these new demands.

The Report of the Committee on Weights and Measures Education was inimously adopted by the Conference.)

\section{PORT OF THE COMMITTEE ON LEGISLATION, PRESENTED BY \\ R. E. MEEK, CHAIRMAN}

CCRETARY's Note.-The text of the Model Regulation for Package Marking Reuilements, which was tentatively adopted by the Conference, is not included $\rightarrow$ this publication. Upon request, the full text of the Regulation is availble from the Office of Weights and Measures, National Bureau of Standards, Tashington $25, \mathrm{D} . \mathrm{C}$.)

The principal activity of your Committee on Legislation during the it year had to do with a study of existing regulations designed to e with problems relating to informative and correct net-content laing of prepackaged commodities. As a result of these studies, your mmittee is prepared to propose the tentative adoption of a reguion as authorized by Sections 7 and 19, Form 2 of the Model Law. First, and by way of background, your attention should be called the resolution adopted by the Thirty-Fourth National Conference, ich proposed the appointment of a Special Committee on Unim Regulations. This committee was duly appointed and reported both the Thirty-Fifth and Thirty-Sixth National Conferences relae to its studies and recommendations. Among the recommendans made and accepted were two of particular interest with respect this report.

The first of these two recommendations was to the effect the Nanal Conference should adopt a model regulation, paralleling the culations promulgated by the Federal Food and Drug Administra$\mathrm{n}$, for the guidance of those States authorized to adopt such a sulation under provisions of their weights and measures laws. nce so much of the work of weights and measures officials in the kage field concerns food products, the importance of uniformity ween the Federal Food and Drug Administration's regulations I any model regulations to be adopted by this Conference cannot overemphasized.

The second recommendation pointed out that the Committee on liform Regulations was a temporary and not a standing Commitand for this reason should be discontinued and its field of acity assigned to the Legislative Committee with authority to draft l offer for adoption such model regulations as may seem desirable l consistent with the Model Law.

ivith the adoption of the report of the Special Committee on Uni-m Regulations by the Thirty-Sixth National Conference, which jort contained the two recommendations just referred to, your Comttee on Legislation accepted the new responsibility. It proceeded, its initial effort along this line, with the drafting of a proposed tative regulation providing for informative and correct net-content eling of all prepackaged commodities.

[Che proposed regulation, with the exception of the legal terminology and at the beginning and end of the regulation, which the Commiton Legislation is offering for your consideration, was taken largely 
from the regulation promulgated about ten years ago, under autho] of the Texas Net Container Act. It is our understanding the Te regulation has proven to be very satisfactory in that State in cop with problems relating to informative and correct net-content la ing of prepackaged commodities.

The suggested regulation was carefully drafted to cover all I packaged commodities and, at the same time; not conflict with ex ing State and Federal food and drug regulations. To avoid confli which would certainly jeopardize enforcement, it was considered visable to use, in many instances, the same language as was founc the Federal regulations. The importance of uniformity between Federal regulations and the proposed model regulation was not or looked during the time this matter has been under consideration the Legislative Committee.

The enforcement of a regulation, modeled after the Federal F, and Drug Regulations, would benefit from the departmental ruli and court decisions handed down over a period of several years. Si a considerable number of States have enacted food and drug legis tion and adopted regulations virtually identical with the Federal Fi and Drug Law and accompanying regulations, weights and measu officials would benefit from the cooperation to be expected from St and Federal food and drug officials if informative net-content lal ing to be enforced by them is in agreement with existing regulations this character.

Your committee has brought the proposed regulation to the attent of the Federal Food and Drug Administration and a number of St food and drug officials, with the suggestion it be advised wherein regulation is not in harmony with existing Federal and State n content-labeling requirements. Since no conflicts have been poin out, the committee is of the opinion no serious ones exist.

The proposed regulation requires that the name of the manuf turer, packer, or distributor appear on the label or labeling of all p packaged commodities, as well as the business address of such ma1 facturer, packer, or distributor. It requires a statement of net ce tents on all prepackaged commodities, establishes reasonable var tions or tolerances to be allowed, and makes exemptions as to sm packages. All of these provisions are set out in necessary detail.

(The Committee also gave consideration to a Bill in the House of Represel tives of the United States Congress, H. R. 7128. This is a bill to permit transportation in interstate commerce, under certain conditions, of packag food products without having shown on the labels thereof, the net contents such packages. The recommendation of the Committee follows:)

The committee does not recommend approval of this bill as, in opinion, if the bill were enacted into law, it would prove inefficie unworkable, and undesirable for the following reasons:

1. At the present time the Secretary of Agriculture has only limit jurisdiction over packaged foods as his jurisdiction is limited to fre fruits and vegetables and to meats and meat food products moving interstate commerce. This bill, if enacted, would lead to divid responsibility as to the labeling of a given product. In other wor the Food and Drug Administration would have the responsibility the correct labeling of the product in all respects except the weig declaration on the package which would become the responsibility the Secretary of $\Lambda$ griculture. 
Enactment of this bill would have the effect of repealing certain risions of the Federal Food, I)rug, and Cosmetic Act relating to eling of food products.

Enactment of Federal legislation of this character would make lifficult, if not impossible, for the various States to enforce their sting laws which require all prepackaged commodities to be labeled ndicate net contents at the time of sale or offer for sale.

The provision in the bill requiring the tare weight of the packagmaterial, container, or wrapper to be placed on the package is rorkable because the variations in packaging materials would make mpractical, if not impossible, to provide an accurate tare weight each package.

Enactment of this bill would result in shifting responsibility for urate quantity labeling from the manufacturer or processor to the iler and, at the same time, deprive the retailer the protection now rded him by accurate quantity labeling in the buying and selling sommodities packaged by the manufacturer or processor. In other ds, the retailer, upon receipt of a shipment of prepackaged comdities, would have no way of determining if any shortages found him were due to normal shrinkage, to conditions which normally ur in good distribution practice, or were actually shortweight at time shipment was made.

Existing Federal legislation covering the net-content marking food sold in package form in interstate commerce is adequate, and activities of State and local weights and measures officials plus activities of the Federal Food and Drug Administration and variregulatory officials provide adequate protection to the consuming lic.

Any additional requirements designed to give greater protection he consuming public in the interstate shipment of food should be le within the framework of existing laws.

The Report of the Conference Committee on Legislation was adopted by the ference. This action included tentative adoption of the Model Regulation Package Marking Requirements.)

\section{OUR WORK IN THE FIELD}

By Alfred Di Piero, Superintendent of Weights and Measures, Camden, New Jersey

Veights and measures has, as we know, been in effect and practiced ne manner or another ever since man has existed on this earth. attempt to explain the prehistoric methods of weighing and meas$\mathrm{g}$ and other supplementary systems is not within my scope. Mine describe to you briefly a part of the activity of the most important in this great weights and measures profession, the man in the field. iy the man in the field, I mean that individual who actually goes every day equipped with his standards, be they weights or measIt is fair and just at the outset that I point out just how ortant this man in the field really is in the overall picture of ghts and measures. $\mathrm{He}$ is the ultimate judge of any quantity rmination. He is the man who places the weight, regardless of on the scale, the liquid in the measure, and the package on the e, to adjudge trueness and accuracy. $\mathrm{He}$ is the man who detects cheat, presents the case before the court, and is constantly under watchful eye of the public, because he is the man whom they see, lally carrying on the work. 
Whe may view with pride the tremendous progress that has ber made, and is still being made, in the field of weights and measurt The basic foundation for 90 percent of this progress which involv changes in engineering, in the laws, and in the methods, is the result . the inspection of equipment, under actual operating conditions, 1 these field men. The snags that they encounter in the courts, al the response of a scale or pump when a test is applied, are the elemen that bring out whether a law is applicable, or an article is fit $f_{1}$ use as an accurate measure. The reports of these tests and inspection eventually find their way to these National Conferences, the final lir in a rast chain of cooperation that is prevalent and so necessary maintaining a uniform system of weights and measures throughor the nation.

Our profession, you must agree, is one of the least publicized, mo forgotten, and least appreciated in the government, be it city, count or State. It is a fact that, in most cases, the only time our wor is viewed with any concern is when the purchaser encounters us : a place of business, actually applying the standards. It is then thi the person becomes aware of our existence and views us with quizzical attitude, an attitude that seems to hang between the honest of the merchant and the mystery of the standards that we handl It would be one of the greatest opportunities for public relation if we could then and there give a short instruction on our worl the customer's alertness, and the dealer's obligation, instead of per mitting someone to leare the scene, totally oblivious to the importar operation that was taking place. Occasional newspaper items a1 read, passed on, and forgotten. Talks explaining our work, togethe with displays before civic groups, are a creditable and instructiv means of bringing out our importance, but the viewing of me operating under actual conditions is one of the best means of sellin weights and measures. Our potentiality as an agent of information as a missionary, or an instructor, is great, due to our contacts with th people who are affected by our work.

It makes no difference what your title on the statutes may be whether you represent State, county, city, or township; whether yo are an agent, inspector, superintendent, or assistant; the work i: the field, in carrying out the plans and designs that are made by th governing bodies, is equally important. The assignments in the fiel are not easy, physically or technically. The inspection of an ordinar. gasoline station presents the task of carrying a test can filled wit] gasoline, weighing close to 50 pounds, from the pump to the under ground-tank pipe, for every test that is made. The ordinary station having three pumps will mean a minimum of six trips if then are no discrepancies, the maximum being dependent upon the result of adjustments. 'The calibration or meter test of tank trucks present a dangerous and umpleasant task, dangerous in the climbing abou the trucks, and umpleasant in the grime and wear and tear on clothing Then, too, there are heavy-duty scales, which demand the utmos of physical exertion in every test. I enumerate these activities witl the purpose of reminding you who do the actual work, the reasol for a certain tired feeling that seems to prevail every midafternoon

Officials, whose work confines them to the office, perhaps may fee that they are not playing an important part in these various opera tions. Accurate records of activities are one of the most important 
rts of a well-organized department. 'The uniformity of the work ignments, proper cataloging of territories, the dissemination of ormation to the public, and many other details that must emanate $m$ the office are projects that call for careful attention. The two ignments, field and office, go hand in hand in cooperation, both rking in the interest of proper enforcement of laws most vital to public today.

If you are one of these men assigned to a branch of the work that is ry, dirty, or umpleasant, do not feel that you are just another hired id or one of the forgotten. You are a most vital part in the weights I measures organization, and you should take a rightful place in the anization, realize your responsibility, and apply yourself accordly. Without you and your intense interest in the work, we would liave the glowing reports of activities to present to the legislators, reriors, and to the public at the end of each year.

iTe too often underrate our efficiency and responsibility in the work I perhaps neglect to put forth thoughts or ideas that may bring ut a worth-while improvement in conditions. These suggestions always appreciated and should never be underestimated. I know many fine conditions in the State of New. Jersey which are the ult of accepted suggestions from men in the field. Only this year, extensive legislative program was presented to the State legislative lies after conferences between the divisional heads and officials $m$ the various municipalities. Each bill was discussed, and, where essary, changes were made. After the bills had been presented. entire weights and measures personnel was notified to contact their resentatives and to apprise them of the importance of the legisla$n$ that we had presented. This recognition of the importance of (l men, even in the legislative phase of departmental activities, is nething that should never be overlooked or disregarded, for they are integral part of a great department.

our work is demanding and has a dignified tradition. This dignity uld be maintained and guarded with an intense regard, if we are to ther the cause of weights and measures. It would be beneficial if, in time to time, we take an inventory of ourselves. Are we applyourselves wholeheartedly to our job? Are we establishing better lerstanding among the dealer, the official, and the public? Are we public relations agent that we should be? Lastly, and this is oortant, do we treat with respect the people with whom we deal? casionally, we should check our qualifications. Can we, with connce, perform every detail in the category of weights and measures? n we accurately test the drug weights and glass graduates, and the ious meters? Can we apply tolerances where necessary, and make hnical recommendations with confidence? These are items that efficient officers should be able to carry on, regardless of their place he departmental enforcement setup.

Tou are the most important $\operatorname{cog}$ in a fine set of gears, operating a hly precisioned machine. If you are not perfectly fitted to this $r$, or if you are a trifle out of alinement, the entire machine is own askew. This indeed would be catastrophic and would curtail honorable profession. Therefore, it is important that the link ween the field men and the superiors be one of everlasting duration, ough at times the conditions may be trying.

cometimes the titular office is a political football. This is indeed ortunate and should be eliminated. There may be other strained 
conditions brought about by events orer which we have no conts TVe do always have one consolation. Regardless of such exigenci our work is one of honesty, and, as long as we perform it in an hon sincere manner, time will solve the rest of our problems.

Be fair with rourself in your application to your work. Be und standing and courteous to those whom you serve, honest and upris in your dealings with rour superiors, and relentless to those w attempt to destror the rules that you enforce.

Lastly, if you have a reights and measures association, and ert department should have one, you should be interested in its actiriti Attend its meetings, air the mutual problems, and discuss matters th may tend to bring about better conditions. Support the legislati programs that are proposed from time to time.

I appreciate this opportunity to appear on this Conference progr: and to deliver this brief talk on one of my farorite subjects.

\section{SAL'T LAKE CITY AND ICE CREAM}

Br E. C. Westwoon. Eeater, Department of Weights and Heasures, salt La ('it). Etah

In Norember of last rear the Salt Lake City Commission reris the Weights and Measures Ordinance by the addition of a new Sectir known as "Section 6638 Ice Cream and Related Frozen Food Produc to be sold by Weight." This law was to become effective in May this vear.

During the interim, between the time the law was written and ma public and the time it was actually to become effective, the Etah I Cream Association entered into the picture and strongly protested i adoption. It was their contention that a weight law governing $t$ sale of ice cream would be impractical and would impose upon t] industry an almost imposible task in attempting to comply with su a law. In the first place, ther argued, ice cream is packaged by han and the process, to a great extent, is guess work. As each carton filled the operator cuts off the flow. For one individual to contim this process hundreds of times each dar and arrive at an exact weig] in each carton would be impossible.

Another problem. industry argued, was that involving the differes solids used in the rarious flarors ther are required to produce. Tl basic flaror is normally ranilla, and the addition of other ingredient such as fruits and nuts. increases the weight. 'This. they conten would necessitate the marking and weighing of each carton after is packed. The ingredients used by the different manufacturers an the rolume of over'un varies in each brand. In order for each mam facturer to pack a certain weight (depending on the overrun and th ingredients used) he would. of necessity, be required to order cor tainers of a size to hold that desired weight. His competitor. usin a different base and overrun. Trould be required to order containes of a different size to pack the same amount of ice cream. 'This, the argued, would not only create a serious problem for them but woul bring many headaches to the weights and measures inspectors.

The problem of temperatures of the different freezing units th ice cream is kept in. from the time it is manufactured until the time $\mathrm{j}$ is actually consumed, was argued and also the element of shrinkag These arguments and others were used by the Association represent atives toward conrincing the Commission that the law was imprac 
21. It is not my desire to burden you with drawn-out details of se arguments. The pros and cons of argument have been given exhaustive treatment, and there are voluminous records on the ject. While there has been much public demand, as directed to ights and measures agencies, for the adoption of sale by weight, en the final showdown comes, the public does not put in an appeare. The result is the Association representatives usually prevail. n our particular fight in Salt Lake City we were a little disapnted in the retail dealers who have always backed us and encouraged sale of ice cream by weight. When the chips were down they did come forth and support the proposition as we had hoped they uld. After many weeks of constant interruptions by the Associan members the Salt Lake City Commission secured withdrawal of law which had not yet been in actual operation. The arguments ntioned above had considerable weight on the ultimate action of the

Commission, but their strongest point, in my opinion, was the that Salt Lake City is only one of many distributing points for ir product in the State of Utah, and that to have a weight law in It Lake City and not elsewhere in the State of Utah would create efinite hardship on the industry and would slow down the efficient ration of dispensing their product. In addition there would be expense involved in marking and labeling of cartons and the ingeover required in machinery. This point was strongly stressed the Association.

in Norember of last year, when we were successful in having the e-of-ice-cream-by-weight law passed, we were elated and proud to nk that Salt Lake City was the first municipality to pass such a ulation. It was felt we had started the ball rolling toward our imate goal of ice cream by weight in the State of Utah, and eventur in all of the 48 States. This, gentlemen, is still our goal. Public nand for the sale of ice cream by weight is becoming more proinced each day. More and more retailers have adopted this method $I$ the public is becoming more accustomed to purchasing ice cream this manner. The old factor of custom, which has been so expertly sounded by the Association in their opposition to this law, is bening a lesser consideration. The argument of lack of proper manery and weighing devices can no longer be considered a threat to ultimate goal. Modern weighing devices and machinery have, in ent years, completely tabooed this argument. Sale by weight will ablish equity between manufacturers and dealer's and will promote esty in the dispensing of this product.

n 1925 V. F. Hovey, then president of the National Association Ice Cream Manufacturers, in his remarks to the 18th National ference on Weights and Measures, stated: **** the intry believed that the public was only interested in buying ice cream rolume." Whether this statement was right or wrong, I cannot say. all probability, the public had not actually given it much thought. ce 1925, however, many industries have streamlined their packagand merchandising methods. This has been especially so in recent rs, since World War II. Nany of these changes have been made by ustry because they could see where modern packaging equipment ld better protect and better display their particular product, makit more acceptable to the public. Many of the modern changes e also been made because more rigid laws have been adopted by 
our respective States. Ultimately, of course, the aim is to pror better protection for the public.

It was my hope to give to the Conference, at this time, a report $c$ ering the law after it was in force and to give you the reaction of public and the dealers to it. I still think, regardless of what the $A$ ciation representatives say to the contrary, that it will be highly ceptable to the public, and that weights and measures departme will receive nothing but favorable comment from it. Although, my knowledge, there are presently no laws in the United States wh require the sale of ice cream by weight, the efforts of the weights : measures inspectors toward encouraging such method of sale is be felt. There are many localities in the United States today where tail dealers are adrertising and selling by weight and are doing with good reaction from the public. This program has been going in Salt Lake City for the past three years. The retailers using $t$ method advise me that public reaction to it is excellent, and the ce plaints regarding measure received are practically nil as compared the complaints they received when they were dispensing ice cream volume. This is also true so far as our own weights and measures partment is concerned. In the retail establishments where this pol has been in force I cannot recall of one complaint that has come if our office regarding short measure. With this type of reaction I c not help but feel the ice-cream-by-weight law will soon be a reality many localities. The sale of ice cream has been one of the bigg headaches with which weights and measures departments have be faced, the reason being that we have not had proper laws and res lations to control it. I, for one, want to eliminate this difficulty, a I am sure this can be accomplished through the combined efforts all weights and measures departments.

If you agree with my thoughts on this subject, may I take this c portunity to offer a few suggestions, which, incorporated with yc own thoughts and ideas, will help all of us toward reaching our desil coal. (1) Every time a newspaper reporter walks into your off give him something to write about on this subject. (2) Whener you are asked to talk on Weights and Measures bring this subject in your discussion. (3) Give a word of praise to the dealers in your a1 who are using this method, and encourage others to do so.

All these things go toward informing the public of the advantar they derive from this method of sale. The public generally does I give much thought to matters of this kind, because of the old est: lished custom. It is second nature for an individual to walk into ] favorite ice cream parlor or fountain and request ice cream by $t$ quart or by the pint. With proper publicity, through the medium our local newspapers, and the combined efforts of weights and me: ures inspectors and dealers, this habit can be changed. When $t$ public is once convinced of the value they receive from sale by weig and the necessity for legislation to control the sale of ice cream, o problem will be solved. It is the desire of all weights and measu officials, I am sure, to protect the public in its purchases of ice crea It is the right of the public to expect this protection. Industry $h$ the protection of experts; the public is entitled to protection by la 


\section{ET-WEIGHT MARKINGS OF PACKAGES AND CANS OF 'TOBACCO}

G. H. LeItHAUser, Senior Assistant Superintendent of Weights and Measures, Baltimore, Maryland

One of our inspectors, in the regular comrse of his work, reported me that packages and cans of tobacco were not marked as to the $t$ weight of the contents. As a result of this report, I wrote to S. Bussey, Secretary, National Conference on Weights and Meases, as follows :

Do you consider the Gorernment tax stamp on the outside of cans of xlanger and Model tobacco as complying with Weights and Measures Laws which say that ". . . it shall be unlawful to keep for the purpose of sale. ffer or expose for sale, or to sell any commodity in package form, mless he net quantity of the contents be plainly and conspicuously marked on the utside of the package in terms of weight, measure or numerical count, stc." These tobacco cans do not show any net weight statement on them, xcept the Government tax stamp which shows that the contents of the cans re either 14 or 15 ounces.

As a result of my letter, I received a reply from M. W. Jensen, isistant Chief, Office of Weights and Measures, National Bureau Standards. Mr. Jensen advised that Mr. Bussey was out of the y. He stated further that he had investigated the matter and had icussed the problem with a representative of the United States reau of Internal Revenue, who advised that the tax-stamp declar:ain literally indicated that the quantity contained was not more than e weight printed on the stamp when the product left the factory. . Jensen stated that apparently the practice of the industry is to dicate no net quantity upon the exterior of the can and to depend on the tax stamp to serve in lieu of a quantity declaration. This ems to be a practice of long standing. It was the opinion of the fice of Weights and Measures that such labeling might be questionle under strict interpretation of the provisions of the Model Law. On receipt of this letter, I wrote the various tobacco companies as llows :

Our Inspector reports that you are shipping packages and tins of tohace, o this jurisdiction not marked as to the net weight of the contents in the arckage.

Your attention is invited to Article 20, Sections 16 (a) and 16 (b) on page 9 , ordinances relating to weights and measures, a copy of which is enclosed.

Please advise us promptly what steps will be taken by your company to orrect this condition.

I received replies from the various tobacco companies, the sumary of these replies being about as follows:

Our pipe smoking tobacco containers do not have any statement of the rreight of contents printed or lithographed on the tin containers. All such containers, however, which leave the factory and which are shipped within the continental United States bear United States Internal Revenue Stamps affixed according to law across the top opening of the container. Such stamps state the weight of the contents of the package to which they are affixed. We believe that the presence of the excise tax stamp on the packages of tobacco is being accepted by States, having laws similar to the law of Maryland, as being the net weight declaration of the contents of the package.

From the above, you can see that the problem involved here is as tlined in my first letter to Mr. Bussey. Does the Government tax amp on the outside cans of tobacco comply with weights and meases laws on declaration of net content of packages? 
If we decide that the Govermment tax stamp could be construe a net weight declaration, then all the weights and measures offic who have the power to do so should adopt a regulation condoning $t$ practice. If, on the other hand, the Conference feels that there sho be a definite net weight statement on the packages and cans of bacco, I would propose that we give the tobacco companies one year which to exhaust their present supply of lithographed cans.

I might state here that most of the tax stamps on cans of Gran and Velvet tobacco are covered by the lid of the can. That port not visible includes the weight indication. Such weight indicat does not appear on the outside of the package.

If we decide that the tax stamp does constitute a net weight ma ing, as required by law, I suggest that Liggett and Myers Toba Company be notified to paste their tax stamp completely on the o side of the package so as to comply with the law.

I have an open mind on this subject as to whether or not the stamp should be construed as a net quantity declaration, but I that, for the sake of uniformity, all jurisdictions should settle $t$ question at this Conference, if practicable.

Mr. O'Conor: I am representing the P. Lorillard Compa manufacturers of smoking tobacco. Our position is this. We $f$ that the Internal Revenue stamp is sufficient to protect the public, a we feel that another declaration on the can would serve merely to ci fuse the public. In addition, it would be a needless duplication.

To substantiate our contention, I refer you to the last paragraph the report submitted by your Committee on Legislation, in which tl say existing Federal legislation covering the net content marking food sold in package form in interstate commerce is adequate; a that the activities of State and local weights and measures offici plus the activities of the Food and Drug and various regulatory o cials provide an adequate protection to the consuming public.

Tobacco tins are made in Baltimore, for example, by the Fede Tin Company, for many sellers of tobacco. Those tins are tl shipped empty to Winston-Salem, North Carolina, Richmond, Louisville, wherever they are to be packed. Since the can manuf: turer wonld be unable to designate which cans are to be shipped int, given juriscliction after having been filled, we feel that Mr. Leithau: is perfectly correct when he says that we should have a uniform polir You gentlemen should decide either that the public is protected by $t$ present declaration on the Internal Revenue stamp, or that somethi else is rieeded. It would be a terrific hardship and burden on tobaceo people if a special declaration were required in only one two communities and not throughout the country.

You might be interested in the regulations of the Internal Reven Department with regard to the stamps which must be placed on 1 baceo tins. They provide that the packages must contain up to 15 , or 16 ounces. Then they say that manufacturers are required put up their tobaccos, etc., in certain packages, and in no other mann A statutory package of tobacco means a package which contains or that article upon which the tax has been paid and no other substan or thing. The contents of a statutory package must be limited to $t$ net number of pounds or ounces of tobacco or snuff, etc., indicated the stamp affixed to the package. 
think you will agree that tobacco nen are not going to pay for a ounce stamp if they are only going to put $14 \mathrm{or} 1.5$ ounces of tohaceo the package.

am sure you will agree with $\mathrm{Mr}$. Leithauser that the companies e been very conscientious in giving the exact weight in the package it is indicated by the stamp on the outside.

If you feel that the Internal Revenue Stamp, which states the net ight, the net weight only, is not sufficient to protect the public, I uld suggest that this be considered. It might be possible to have the ermal Rerenue stamp contain a trifle more information.

It any rate, our basic position is that the public is not being consed or deceived by the present practice, and that needless duplica$n$ would result if we changed that practice.

Mr. Kexnedy: I do not agree with Mr. O'Conor that the Interna? venue regulations protect the public. He used the word "limited." imited" means that they camnot go above the weight indicated on s stamp. It says nothing about giving less than that weight. Hower, we are having no trouble with tobacco, and they are being conentious about putting the weight in. As long as they do that, I commend that we leave them alone. When they fail to do that, let pass a regulation which requires a marking on the can.

Mr. BuIckeY: It has been an accepted practice throughout the ates, and I know especially in Pennsylvania, that we recognize the deral stamp as a declaration of contents. However, I am certain it a violation not only of the Pennsylvania law, but of every other law hich states that the net content must be declared on the outside of e package.

I would suggest that we place this subject in the proper committee, t them study it for a year, and bring it before the Conference next ar, when a final decision can be made. In the meantime, we should intinue to recognize the Federal stamp as a content declaration.

Mr. Ragland: I am Executive Secretary of Associated Tobacco anufacturers, located in Washington. We are a trade association hose members manufacture erery type of tobacco product sold in ie 48 States of this country and in many other countries throughout le world.

Tnlike most commodities, tobacco is under control of a governental agency from the time the leaf is first sold by the farmer until re consumer purchases the finished product. Even the grower of bacco, in most instances, is controlled as to the amount of acreage may use in planting his crop.

My purpose in being here today is to submit, first, an explanation f why the Federal Internal Revenue excise tax stamp is suitable and mple indication of the net weight of a package of manufactured bacco at the time of its removal from the factory and, secondly, to squest that this Conference adopt a resolution accepting this evidence f tax payment as satisfactory compliance with those ordinances and i $\pi$ s requiring net weight markings on packages of tobacco.

Section 2100 of the United States Code and the definitive regulations isued by the Commissioner of Internal Revenue provides:

All manufactured tobacco shall be put up and prepared by the manufacturer for sale, or removal for consumption, in packages of the following description and in no other manner : (a) Size 
This subparagraph sets forth the weight denominations cover net weight contents of packages of tobacco.

In Section 2002 of the code you will note that:

The commissiomer shall cause to he prepared suitable and special staml lor the parment of the tax on tobaceo and snuff, which shall indicate th weight and class of the article on which payment is to be made.

Article 52 of Regulation 8, which implements this section of code, states:

Each package containing a statutory quantity of tobacco or snuff shal hefore removal from the bonded factory premises where made, have aftixe thereto the proper internal revenue stamp or stamps of such denominatio. is will cover fully the tax on the net weight of the contents. . . .

(a) Every package containing 16 ounces or less of tobacco or snuff mus be tax-paid by affixture of a single stamp of the proper class an denomination.

Irticle 110 of Regulation No. 8 reads in part as follows:

Manufacturers are required to put up their tobacco, snuff, cigars an cigarettes in certain packages and in no other manner. . . The content: of a statutory package must be limited to the net number of pounds o ounces of tobacco or snuff, or the number of cigars or cigarettes, indicated by the stamp affixed to the package. . . .

In addition to the aforementioned controls, Article 41 of Reg lation 8 requires every manufacturer of tobacco or snuff to keep book in which is entered daily an accurate account of the quantiti of the different kinds of manufactured tobacco and snuff produce removed tax-paid, or in bond for export or for use as sea stores, withdrawn without payment of tax for use of the United States. addition, this record must indicate the value of all stamps purchas and used. Severe penalties are prescribed for those failing to comp with these requirements.

If this were not enough to exact compliance, please consider t] economic aspect. I shall not dwell on this point because surely yc can understand why tobacco manufacturers would not pay for a affix to packages of tobacco revenue stamps of larger denominatic than is actually required by the net weight involved.

The ordinary conduct of interstate trade is complex enough withor making matters more difficult. All sensible people are sympathet with the objectives of your assignment. The days of "caveat emptor are outmoded, and that is only proper in this age of enlightenmen Likewise, you officials who are charged with public trust of protectin the consumer against unscrupulous purveyors should adopt a realist: attitude in the fulfillment of your duties. Tobacco manufacturers al honorable businessmen, and I ask you not to place hobbles on the merchandising flexibility. I urge you gentlemen to advocate th acceptance of the Federal Revenue Tax stamp as prima facie eviden of the net weight marking on packages of tobacco.

(At the conclusion of the discussion, a motion was made, seconded, and adopte that the matter of content labeling of packages and cans of tobacco be referre to the conference Committee on Legislation for consideration and recon mentation.)

\section{SALE OF PEAT MOSS}

Bx T. A. Cartel, Supervisor, Division of Standards, State of Washington

We in the State of Washington, as well as persons in other States o the United States, feel that some regulatory action should be takel 
parting the packaging of peat moss. We have felt that such action iuld be desirous, and that industry needs some legitimate packaging ndards, particularly in reference to baled material. 'There are tain companies who put out baled peat moss that has a compression tio of $21 / 2$ to 1 , and the size of the bale is 36 by 18 by $20 \mathrm{in}$. (outside :asurements), and that is quoted as a standard bale, and is sold as sh. Other companies make a smaller bale, and a little shorter, in th length and width, and compress it much less, and this is also sold a standard bale.

We have thought of drawing up regulations regarding the sale of at moss, but before doing so we have communicated with other States ative to this subject. Some States favor weight markings, and some ror measure markings. It seems that most of the States that are st concerned, and have made somewhat of a study of the subject, feel statement of quantity in connection with peat moss, should be in 'ms of cubic content, that is, 7 cubic feet, 5 cubic feet, $31 / 2$ cubic feet, ., with the additional stipulation that the volume as contained in respective containers be compressed in a 2 to 1 ratio. The reason favoring a statement of cubic content rather than by weight is due the fact that weight markings in this instance can be used for the rpetration of fraud because of the high moisture content.

Of course, it is to be realized that there are a great many factors to f. considered, and no doubt any set of regulations or laws that may adopted will meet with objections from many sources.

I am at this time presenting the subject of peat moss markings to is Conference for consideration. I am sure that any action taken by u will meet the approval of the States.

Discussion of the Sale of Peat Moss was deferred until after the presentation the recommendation of the Conference Committee on Methods of Sale of Com(dities. This will be found on page 58.)

\section{WIPING GLOTHS}

\section{J. E. Brenton, Chief, Bureau of Weights and Measures, State of California}

It is the opinion of the weights and measures officials of the State of lifornia that the attempt on the part of certain persons to legalize sale of wiping cloths by gross weight was an endeavor that, had it ceeded, would have jeopardized every principle of honest merchansing, principles upon which the economic foundation of every civild nation is based. A future argument could well be presented and fended that fruits and regetables should be sold based on the weight the contents and wooden crate; bulk grain in cars sold on the basis the combined weight of the grain and car. These possibilities may ind ridiculous, but I assure you that arguments in favor of selling lits, vegetables, and coal on the basis of gross weight are just as fensible as were the arguments that were advanced in an endeavor perpetuate the mistake that we, as weights and measures officials, re permitting to take form by our lackadaisical attitude with respect those dealers of wiping cloths who insisted on selling their product the basis of gross weight.

In the State of California, a bill was introduced in the State Legisure, the provisions of which permitted the lawful sale of wiping ths on the basis of gross weight, meaning that the basis of settlement uld be the combined weight of contents and container. This pro- 
posal actually passed the Assembly of our State Legislature, but were successful in preventing any finther advance.

The proponents of this bill used three principal arguments. 'Thi wele:

1. The weights and measures officials of the State of Californ were alone in their requirement that wiping cloths should be sold, the basis of net weight, and, as a result of what they claimed was a lo effort to enforce net weight, the dealers in the State were being pen: ized because ther could not economically compete with out-of-Sta (lealers who were offering wiping cloths at a lower cost per pour based on a weight that was a gross weight. Also, when wiping ra. were shipped into the State for lesale, in containers bearing a stat ment of quantity in terms of gross weight, we could not require th the containers be remarked with a statement of quantity rearling terms of net weight. It was also stated that the different agencies the United States Gorernment purchased their entire requirement wiping eloths on the basis of gross weight.

We comntered these respective contentions by writing to the reigh and measures officials of trentr different cities and States, inquirir as to their acceptance of gross weight in lieu of net weight in conne tion with the sale of wiping cloths. Without a single exception, tl answers supported, without equirocation or reservation, the stand: recommended by the National Conference, that wiping rags shoul le sold on the basis of net weight.

A request was made of the Attorner General of the State of Cal fornia for an Opinion as to whether or not we could require that statement of quantity in terms of net weight be placed on a contains of wiping cloths shipped from out-of-State to California for re-sa in California, and also whether or not we could require a dealer i California to sell wiping cloths on the basis of net weight, wipin cloths that he had purchased in another State on a basis of gros weight.

The Attorney General supported our Bureau in both instances. Th containers, when offered for sale in California, must bear a statemer of quantity in terms of net weight. and the sale itself must be on th basis of net weight. (Copies of this Opinion may be obtained upo request to $\mathrm{Mr}$. Brenton.)

Mr. Busser, our National Secretart, air-mailed a copy of Feder: Specification DDD- $1 \mathrm{~T}-415$, and the provisions as contained in thi particular specification definitely refuted the claim concerning gros weight purchases by Federal agencies.

The prompt replies of twent $\mathrm{x}$ State and city weights and measure officials. the provisions of Federal Specification DDD-TV-415, and farorable Opinion from our own State counsel all combined in block ing any additional vote gaining, on the basis of the arguments that have noted.

2. The Office of Price Stabilization would not permit the industr. to sell on a net-weight basis due to the fact that the price as establisher by that agencr was on the basis of gross weight. This opinion prover to be the opinion of one man and was not supported by the Washing ton office of the OPS. Again, through the cooperation and assistance of $\mathrm{Mr}$. Busser, this aroment was quickly and definitely refuted.

3. Their thind, and final, contention was that the weights anc measures officials were permitting the sale of wiping cloths on the basi: 
gross weight throughout the United States, and the practice should be disturbed.

Jur reply was to the effect that we were not employed to perpetuate takes, and that the sales of wiping cloths must be on the basis of weight.

As an example of a sale by gross weight, we shall offer you the lowing:

A county purchasing agent in a county in California ordered fifty pound cartons of wiping cloths. 'The actual net weight of these cartons averaged $461 / 2$ pounds, an overcharge of $31 / 2$ pounds per ton, making a total overcharge of 175 pounds. One hundred and enty-five pounds at $251 / 2$ cents per pound equals $\$ 44.62$. You can 11 imagine the hue and cry that would have been raised had an oil mpany deliberately short-measured this county 223 gallons of gasoe, which is the quantity that $\$ 44.62$ would purchase at 20 cents a Alon.

When ordering a bale or carton of wiping cloths, you specify "white ping cloths" or "colored wiping cloths." We do not construe or ept the burlap wrappings to be either a "white wiping cloth" or a lored wiping cloth," and have insisted that the weight of such rlap wrapping and tie wires be considered as part of the tare.

As previously mentioned, we are of the opinion that the effort to alize the sale of wiping cloths on the basis of gross weight was an ening wedge, and, because of this probability, we could not afford to npromise in any manner, shape, or form.

It is probable and possible that, in the future, efforts will be made, her through the medium of legislation or adoption of regulations, legalize the sale of wiping cloths by gross weight.

As your associates and coworkers, the county and State weights d measures officials of the State of California urge you to fight any sh move without compromise.

The Conference was recessed until 2:00 p. m.)

\section{FTH SESSION-AFTERNOON OF THURSDAY, MAY 22, 1952}

(J. Fred True and R. D. Thompson, Vice Presidents, presiding)

\section{REPORT OF THE COMMITTEE ON METHODS OF SALE OF COMMODITIES, PRESENTED BY J. G. ROGERS, CHAIRMAN}

Preamble.-Your Committee on Methods of Sale of Commodities sents its report for consideration and such appropriate action as Conference may decide upon in relation to its several sections. re principles, purposes, and policies under which this Committee nctions have been explained in former reports and we believe are w well understood. They are accordingly not being recounted here. The attention of this Committee was focused upon the following ms since the last Conference. Our recommendations in relation them, as now offered for your consideration, represent what we em to be reasonable; fair, and proper solutions of the problems enled in these various issues, as to methods of sale.

1. Soap (Bars and Cakes).- Should be sold by numerical count and number of bars or cakes in a package should be stated on the outle of the package in a plain and conspicuous manner, provided, wever, that where a package contains only one bar or cake of soap h declaration or statement should not be requires; and provided, 
further, that these stipulations shall not apply to medicated soar required to be marked by weight under the Federal Food, Drugs an Cosmetic Act.

Note. - This item which had dereloped controversy after being given what we assumed to be final action by the $34 t h$ National Conference was reopened at th 36th Conference in 1951 and after' debate was referred back to your Committ by vote of the Conference, for further study and reconsideration. Your Commi tee now offers the foregoing recommendations for final adoption.

2. Ice Cream and Ices on Sticks.-Novelty items of ice cream an ices frozen on sticks and sold in package form shall have the quantit of contents declared in terms of avoirdupois net weight or in terms $\mathrm{c}$ net volume by fluid ounces.

Note.- The 36th National Conference adopted a recommendation that thes novelty items of frozen products when sold in package form "shall have th quantity of contents declared in terms of avoirdupois net weight."

This was presented as Item 9 of your Committee's report with an appende note of hasic reasons for the requirement. Subsequent to that conference th inferests most directly affected male representations to this committee t reopen the subject for further consideration, as it was their belief that whil we had acted in all sincerity of purpose, we were possibly not in possessio of had knowledge of all facts in relation to this issue, which could affect th decision we had reached. Consistent with adopted policy, a review of th subject was granted and the Committee then launched a research of all phast, involved. The resulting determinations were such as to conclusively show the there are many technical ramifications and other factors related to the issu with which we were not familiar, and that our original recommendation $t$ the Conference was premature.

Consequently what first appeared to be a simple matter to settle became on of considerable proportions and through the further facts we have gathere has impelled this Committee to now offer the recommendation that the actio taken at the 36 th National Conference on this item be rescinded and that th following recommendation be adopted in substitution:

Ice Cream and Ices on Sticks.- Novelty items of ice cream and ices froze on sticks and sold in package form shall have the quantity of contents di clared in terms of avoirdupois net weight or in terms of net volume by flui ounces.

This now makes declaration by volume permissive, and for which full just fication has been found.

In the interest of brevity the many technicalities and phases entering int our findings are not incorporated in this report but can be made available $t$ any member of the Conference who desires to review them.

Among the salient reasons that influenced our final decision are:

(a) That public interest will best be served by the modification of a 1 t strictive requirement which if confined to weight would influence and impos an inclease in cost on a popular commodity.

(b) That consumer economy can be adequately protected by a simple dis placement method of test to determine the quantity by rolume in items 0 this kind.

(c) That it will remove any nuisance factor inherent in this issue.

(d) That it will permit a method of sale with which all manufacturert can readily conform without difficulties that would increase the cost of production.

(e) That the industry will systematically and fully conform with Stat approval requirements in relation to the molds and forms it uses as measurin media in the production of novelty frozen desserts.

(f) That the industry has rendered full cooperation in the efforts to reac proper conclusions on this issue and manifests intention to maintain hig: ethical standards in the operations of their enterprises.

3. Peat Moss in Package Form (T'entative).-The following shal govern the production, packaging, and sale of this commodity. 
Peat moss shall be put up in packages of the following sizes dimensions only.

\begin{tabular}{|c|c|c|c|c|c|c|}
\hline \multirow{3}{*}{$\begin{array}{l}\text { Actual capacity of } \\
\text { package }\end{array}$} & \multicolumn{6}{|c|}{ Allowable size in package } \\
\hline & \multicolumn{2}{|c|}{ Length } & \multicolumn{2}{|c|}{ Width } & \multicolumn{2}{|c|}{ Depth } \\
\hline & Maximum & Minimum & Maximum & Minimum & Maximum & Minimum \\
\hline $\begin{array}{c}\text { cubic feet } \\
\text { or less } \\
\end{array}$ & $\begin{array}{l}\text { in. } \\
41 \\
40 \\
37 \\
30 \\
16 \\
19 \\
13 \\
(\mathrm{a})\end{array}$ & $\begin{array}{l}\text { in. } \\
39 \\
38 \\
35 \\
28 \\
14 \\
17 \\
11 \\
\text { (a) }\end{array}$ & $\begin{array}{l}\text { in. } \\
25 \\
21 \\
20 \\
18 \\
11 \\
101 / 2 \\
8 \\
(\mathrm{a})\end{array}$ & $\begin{array}{l}\text { in. } \\
23 \\
19 \\
18 \\
16 \\
9 \\
81 / 2 \\
6 \\
\text { (a) }\end{array}$ & $\begin{array}{r}\text { in. } \\
22 \\
21 \\
19 \\
15 \\
16 \\
6 \\
6 \\
(\mathrm{a})\end{array}$ & $\begin{array}{r}\text { in. } \\
20 \\
19 \\
17 \\
13 \\
14 \\
4 \\
4 \\
(\mathrm{a})\end{array}$ \\
\hline
\end{tabular}

$\mathrm{n}$ be sold in uncompressed or compressed form, provided content in cubic feet and degree of com$n$ are clearly marked on package.

1) The ratio of compression on peat moss in package form shall ot less than two to one.

) There shall be an allowable tolerance in cubic content not to ed 3 percent of the stated package volume.

\section{Labeling or Marising}

11 packages shall be plainly and conspicuously marked with the tity of contents in terms of cubic feet and/or fractions thereof, ther with the ratio of compression, as, for example, "Contents 7 c feet", "Compression not less than 2 to 1."

\section{General Requirements and Exemptions}

at moss prepared by a process of briqueting, pelleting, or extru, with a compression ratio in excess of 5 to 1 , shall be sold on a ht basis with no limitation on size of package.

pecialty products from peat moss, such as asparagus pads, floral es, floral moss, insulating boards or batts or other specialized is or preparations, shall be exempt from these recommendations.

TE.-The proper method of sale for this commodity has long been a troubleproblem to weights and measures authorities. The production and sale at moss has greatly expanded since the subject was first brought up in hts and measures channels and your committee believes there is now a al opinion that our Conference group should take definite action about it out further delay.

ere has been considerable study given to this topic by quantity regulating orities in various sections of the country, and the recommendation now sub d represents the consensus of those who have conveyed their determinato us.

rst consideration was given to the possibilities of a weight requirement. The y hygroscopic nature of peat moss with its great moisture loss and regain rs influenced the rejection of this thought, as it was quickly recognized that reight method would lend itself to the perpetration of fraud. Such method only be invoked with the stipulation of complete dehydration, and this in obability would be prohibitive from a cost standpoint.

le by dry measurement in elements of the bushel and its subdivisions was considered, but this too presented problems and obstacles that made this od unfavorable. 
Quantity representation by cubic measurement as now proposed would ar to offer the solution which will serve the interests of all concerned and the that can be most simply applied without fear of detrimental results.

Thére is one factor in our proposal that possibly could be further explored that is in relation to the compression ratio. The two to one ratio as recomme represents the determinations of your Committee up to the time of preparing report. There may be practices of packaging within the industry with W we are not familiar and which might influence a revision upward or downwa the compression factor. What we propose in this connection at this tim believe to be reasonable and adaptable. It is in the nature of a standard o for packaging and would give us something to start with by way of regul pending any representations from the industry that would justify an altera To provide for such contingency we, therefore, believe that tentative adoptis the recommendation would be advisable at this time and final adoption $b$ complished with or without changes at the 38th National Conference. would at least place the industry under notice that peat moss has received $t$ ment in weights and measures channels, so that it can anticipate and prepar adjustments within its enterprises.

Your committee recommends the tentative adoption of this ite]

Mr. Graham: We are possibly the largest importers of peat $n$ operating in the United States. The proposed measurements completely at variance with a very big share of the industry. N of the many millions of bales imported has been marked with we or volume. If there is a method of exact measurement, it woulc a great boon to the industry. However, I do not believe that regulation as offered here should be forced onto the industry witl further consultation and consideration of the machinery now in

Chatrman True: The recommendation is for tentative action, the problem is to be taken under advisement until the next Confere

Mr. Endress: We are perhaps the largest American producel horticultural peat. In this discussion you must discriminate beth the different types of peat. The term "peat moss" includes product put up in bales and also the product we package in $b$

The latter is more of a peat humus. It is a natural organic mate and cannot be compressed. We package it in bags and sell it volume or weight-whichever is desired. However, we think $t$. in making rules or regulations, you will have to discriminate betw the different types of peat.

Mr. Turnbulu: The Federal Trade Commission defines peat $n$ as sphagnum peat moss. That is the item before the Confere Does your product come within this definition?

Mr. Endress : That is a question involving horticultural definit In one bog we have sphagnum peat, but it is mixed with all of other types of peat and loses its identity after a certain period decomposition.

Mr. Carncross: Sphagnum peat is a peat humus. It is produ in many points in the United States. I do not think it is inten that this regulation will apply to peat humus. A Federal regi tion requires that the term peat moss be applied only when $75 \mathrm{I}$ cent of the material comes from a moss. I would say that $p$ regulations would in no way affect the producers of peat humus

Mrs. Poppex: The last gentleman is slightly in error. The F Trade Practice rules indicate that any peat may be labeled $p$ moss. However, when it is more than 75 percent sphagnum, or $\mathrm{m}$ than 75 percent seg, it is called "Peat Moss Seg." If we must regulated, we want to assist in the formulation of the regulatic We are packing in bags, 25 pounds or 50 pounds-or the equival in cubic measurement. 
Ir. Rafael, Mr. Goode, and Mr. McBride commented further that the 1od of sale of peat moss seemed to be a very intricate and controversial ect, and that, while they were in favor of tentative approval of the comee recommendation, they were convinced that considerable additional study consultation must be given to the subject.)

Thereupon the Conference tentatively adopted the committee recommenon.)

Permatite or any Material or Substance of the Nature or CharThereof.-When sold in package form shall bear a plain and spicuous declaration of quantity in terms of minimum net conexpressed in terms of cubic feet and/or fractions thereof. Proad, however, that a maximum of 15 percent over measure shall llowed at time of packing to compensate for volumetric shrinkage sed by compression due to handling, stacking or other cause; and rided, further, that an auxiliary declaration of contents shall be - red, in terms of net weight. When dual quantity markings are Jloyed, neither shall be greater than the other in prominence or e a more conspicuous position on the package.

этЕ.-There are differences of opinion on how this commodity should be sold. consideration was given to the method of sale and marking bv net weight. character of the product is such that it has both loss and regain factors. ght variables are, therefore, considerable and inconsistent. The hygroscopic Ire of this product appears to be more pronounced than in other substances I this characteristic and in which the weight method is prescribed. It is, efore, the opinion of this Committee, based on studies that have been made, the method of sale and representation by cubic feet should be invoked and low so recommend. Further in this connection, your Committee is informed there are companies now marketing Permalite under the method prescribed ais recommendation.

Tomatoes in Package Form.-When packed in containers or ys wrapped in cellophane or with transparent or "window-face" shall be marked in a plain and conspicuous manner in terms of limum weight of contents, together with the name and location of packer, repacker or distributor; provided, that a supplemental rking in terms of numerical count shall be permitted contingent on all quantity declarations being of equal prominence as to size l position on the package.

OTE- This is an instance where an industry has taken undue advantage of ral official interpretations of net weight container laws and especially in tion to numerical count declarations. As a consequence, numerical count arations on packages are now of little if any worth as a gage of value to consumer. What can be termed random packing by count with tomatoes of iable sizes and numerical declaration thereof, certainly is adverse under iting circumstances to the principles and purpose of net weight container utes and definitely does not entitle those invoking them to any concessions reby the consumer is left unprotected. The justification of now imposing ecific weight marking requirement on repackers of tomatoes is conclusively nd in the Federal Food and Drug regulations under Section 403 (f) (3) ch provides that: "Unless an unqualified statement of numerical count gives urate information as to the quantity of food in the package, it shall be plemented by such statement of weight, measure, or size of the individual ts of the food as will give such information." What was originally a package omatoes weighing one pound has gradually been reduced by the introduction of tainers and trays that deliver to the consumer as little as 10 or 11 ounces, yet ih the same number of units making up their contents. Your Committee has lored the prevailing situation from all angles, and while it has other ramitions than those cited, we believe that what we have here presented by way easons, constitutes a strong brief for the adoption of the recommendation we offer.

Following the presentation of this item by the Committee Chairman, conrable discussion ensued, including the following.) 
Mr. Mahoney: I think this is more a marketing problem tha: weights and measures problem. As has already been stated, the of these cartons started off on a weight basis. It was found to be practical, and now you are proposing that we go back to that meth

Mr. Kennedy: When these cartons were sold by weight in the I trict of Columbia, we had a lot of trouble with them. I am sure $t$ you gentlemen will find it so in your jurisdictions when you requ a weight on the commodity. I do not believe that you are permit to require "minimum weight." If your laws are like those in District of Columbia, they require that tomatoes and other commodi be sold by "net weight." That does not mean "minimum weigl

I have talked with store owners and operators who are registe here. They are 100 percent opposed to this proposal. Pack tomatoes by weight requires additional handling of the product, : additional handling causes spoilage.

Mr. McBride: In relation to the lack of authority to say that statement in terms of count be otherwise supplemented, the Fede Code permits just that. I think we should bear in mind that, whe weight is given, the consumer has an opportunity to exer selectivity.

Mr. Goope: We have already discussed the proposed Model Re lation for package marking requirements. Under Section (e) (3) says, "Unless an unqualified statement of numerical count gives curate information as to the quantity of commodity in the package shall be supplemented by such statement of weight, measure, or s of the individual units of the commodity as will give such infor tion." Section (d) (2) of this Model Regulation states that " statement shall be expressed in the terms of weight, measure, num cal count, or a combination of numerical count and weight, or meast which are generally used by consumers and users to express quant of such commodity and which give accurate information as to quantity thereof." I believe it has been the general practice to sell a buy tomatoes by weight.

We have had correspondence with W. A. Queen of the Federal Fc and Drug Administration, who was very agreeable to this method sale.

(After additional comment by Messrs. Mullen, Lirio, and Chairman True, question was taken, and the Committee proposal was carried by a vote of ayes as against 24 noes.)

6. Prepackaged Meats at Retail.-When sold or offered for sale self-service markets should be marked with the net weight of conter the basic price per pound and the total cost of the package.

NoтE.-This recommendation speaks for itself. It is designed to prom uniformity in enforcement operations which are now variable as relating to $t$ subject. Those who have adopted this method of sale for meats have done for their own interest and convenience. They should, therefore, assume responsibility for the condition of packages as to weight and pricing so that consumer will have the means of gaging values the same as when making I chases directly at the butcher block or counter.

(The Committee's tentative recommendation included the following stipl tion: "To provide assurance of weight accuracy, all such packages should reweighed by the merchant, manager, or employees within a lapsed time not exceed 24 hours." After considerable discussion by the delegates, the Commit Chairman accepted the recommendation that this sentence be deleted from report, and the report was so amended.) 
IR. Kennedy: It may be all right to say in accordance with the that the package should be marked with the net weight of content. , the price per pound, under no law that I know of, has to be inated on the package.

Ir. How ARD: The buyer has no comparative method of determinvalues unless the price per pound is shown.

IR. KENNEDY: I do not think the weights and measures officials demand that the unit price per pound be shown on the package.

IR. Saxton: We have had four court cases on this matter. It can done legally. We have this requirement in our city, by ordinance. s up for consideration now by the State of Michigan.

IR. Slough: This proposed price requirement is the law in the $y$ of Akron, and also in the City of Columbus, Ohio.

Ir. Rogers: Under the net-weight container law, the weight must sear. You see the basic need for pricing, in connection with your packaged commodities. You have to establish a basic price to find whether you are getting proper value for your total cost. I want explain that we have used the word "should," and not "shall," in ; recommendation.

Ir. Carpenter: Gentlemen, 2 years ago I attended this Conference $i$ addressed you on the subject of prepackaged meats. At that e I dwelt on many of our problems as a retailer endeavoring to ure proper weight determination at the time of sale.

Che original Committee suggestion, that every package be reweighed ry 24 hours, is a necessity on certain items. However, that necesdoes not extend throughout all of the items that are handled the self-service basis in a package meat store.

?oultry, according to our standard, and the standard issued to our rket personnel, must be checked, not for weight alone, but also for dition, every 24 hours. This is the case with variety meats, such liver, etc. We give items such as sliced luncheon meats three ys shelf life before they have to be checked for weight and condition. would be difficult to set a specific time requirement such as 24 hours cover the entire meat line. Sliced bacon, for example, you might as long as 10 to 12 days without a sufficient amount of shrinkage urring to jeopardize the weight factor.

The Committee recommendation, as amended, was unanimously adopted.)

Fractional Terms of Ounces.-When used in connection with intity declarations on commodities in package form, shall be in ments of the ounce divisible by the number two or a power of the mber two.

OTE.-The purpose of this recommendation is to prohibit the use of odd fracis, such as thirds and fifths of the ounce in package markings. There have recent attempts on the part of packers of certain commodities to use terms ch are not in coordination with the standards of weight and measurement mally employed in commercial pursuits and by weights and measures officers. 11 Committee believes that the use of odd fractional terms creates confu; that they would make quantity determinations difficult in enforcement rations through the necessity for conversions; that there is no need in kaging enterprises for refining fractions to elements not representative of sting standards; and that no benefits would accrue to the consumer.

3. Quantity Declaration on Commodities in Package Form.-Whall lude the word "net" in their marking terms relating to the contents such packages by weight or volume. 
Note.-By this recommendation it is hoped to settle the mooted question has come up from time to time as to whether the word "net" should be requ in quantity declarations. There have been rulings permitting the deletion the specific word "net" regardless of the fact that laws requiring quar declarations on commodities in package form generally stipulate that the contents shall be declared. These permissives have been given under the ir pretation that a quantity marking of any kind implies and is intended to $\mathrm{m}$ net contents and that the word "net" is not needed and, therefore, is discretior as to its use.

There have been court decisions and legal opinions that have reversed interpretation, on the premise that if the word "net" is omitted from the desc tion of the quantity of a commodity enclosed in a container, confusion can a in the mind of the buyer as to the actual weight or volume in the package, give rise to possibilities for fraud. It has been further pointed out in s decisions and opinions that the statute directs in no uncertain terms that net quantity of the contents is to be marked on the outside of the package, it follows that to mark the package as to the quantity of the commodity tained therein, without including the word "net" would amount to a failur comply with the mandatory direction of the statute.

This Committee, therefore, offers this recommendation for adoption to es lish uniform procedures among the packing interests and weights and meas officers in relation to the terms employed in quantity markings.

(At this point the remainder of the Report of the Conference Committee Methods of Sale of Commodities was deferred until a subsequent session of Conference. Continuation of the Report will be found on page 72.)

\section{TRAINING SCHOOLS FOR WEIGHTS AND MEASURES OFFICIALS A SERVICEMEN}

By W. M. Hoxie, Service Manager, Bennett Pump Division, John Wood Compc Muskegon, Michigan

(Mr. Hoxie described the organization of a State-wide training school gasoline pump mechanics and weights and measures inspectors. This scl was sponsored by C. D. Baucom, Superintendent; Weights and Measures Divis State Department of Agriculture, Raleigh, North Carolina, and the Instit of Government of the University of North Carolina, and was held on the cam of the University in Chapel Hill. The rarious pump manufacturers participa in the 2-day affair, at which were registered over 450 persons. Mr. Hoxie pressed the appreciation and approval of the manufacturers for such an un taking by a State.)

REPORT OF THE NATIONAL CONFERENCE COMMITTEE ON NOMI TIONS, PRESENTED BY J. E. BRENTON, CHAIRMAN, AND ELECTI OF OFFICERS

The Committee submitted the following nominations for office in National Conference to serve during the ensuing year, or until st time as their successors are elected.

\section{OFFICERS}

For President: A. I. Astix, Director, National Bureau of Standards.

For Tice Presidents: ErLing HANsen, of Minnesota; R. D. Thompson, of Virgin J. F. True, of Kansas; F. M. Greene, of Connecticut; I. M. Levy, of Chica Ill. ; D. G. NeI.son, of Morris County, N. J.

For Secretary: W. S. Busser, National Bureau of Standards.

For Treasurer: G. F. Austin, Jr., of Detroit, Mich.

\section{EXEGUTIVE COMMITTEE}

For members of the Executive Committee: R. E. MEer, of Indiana; J. A. PI ERT, of Sheboygan, Wis.; J. M. O'NeIL, of Cambridge, Mass.; C. H. StenI of South Carolina; M. G. RICE, of New York; H. E. Crawford, of Jacksonvi Fla.; E. C. Westwood, of Salt Lake City, Utah; J. A. Boyle, of Maine ; J. Mahoney, of Maryland; R. W. Searles, of Medina County, Ohio; C. Fuller, of Los Angeles County, Calif.; A. C. SAMEnfink, of Rochester, N. W. H. Ising, of Louisville, Kу.; J. M. Boucher, of Washington, D. C.; R. Dagget , North Girard, Erie County, Pa. 
(Signed) J. E. Brenton, Chairman,

C. A. BAKER,

J. F. BLICKLEY,

J. RoY JoNes,

J. J. LEVITT,

C. C. Morgax,

R. J. ZierteN,

Committee on Nominations.

The report of the Committee on Nominations was adopted and the officers elected unanimously.)

\section{BELT CONVEYOR SCALES}

\section{By R. O. Bradley, Toledo Scale Co., Toledo, Ohio}

$t$ the 36th National Conference on Weights and Measures, Leonard ruire presented a paper to contribute the knowledge and experience he Fairbanks Morse Co. relative to belt conveying scales. In that he pointed out sereral basic reasons why belt conveyor scales offer sendous problems in regard to accuracy. Mr. Maguire's points e well made and quite understandable. In the discussion followhis talk, he made the following statement- "It is a processing e. Some day it may develop into a commercial scale and in some $\mathrm{s}$ there are conditions that are such that it could almost be classias a commercial scale. But generally speaking, it is strictly a cessing or industrial machine.'

Juring the period of the last 15 years our company has had exence with integrating belt conveyor scales. As a result of this erience, we have in the last 2 or 3 years incorporated two new ures which we claim have changed the status of belt conveyor es from the processing class to the commercial class.

t a meeting in February of this year, I explained those features Ir. Maguire to see if he, as a representative of his company, would ee that there was probably some basis for our claim. He agreed $t$ there was probably some basis, but that naturally it would be essary for their engineers to incorporate the features in one of their es, in order to secure test data and evaluate the improvements. the first feature to be explained is very simple. It consists in feedthe speed of the carrying strand of the belt into the integrating ice, rather than the speed of the return strand. We have proven actual belt-speed measurements that the carrying strand on a long jing conveyor may travel as much as 1 percent faster than the ren strand with zero belt load, while traveling 5 to 6 percent faster $n$ the return strand when a belt load of 100 percent capacity is ig carried. Essentially, the integrating device on a belt conveying le multiplies belt speed by belt load in pounds per unit of length. he belt speed that is fed into the integrating device is not the same che speed of the belt passing orer the weighing section, the belted factor, and thus the product of speed and weight, are naturally arror. The result of this error is always a slow reading from the grating device because the return strand always travels slower $\mathrm{n}$ the carrying strand (provided the motor is driving the conveyor d pulley and not the tail pulley). An integrating device using the ed of the return strand can then be accurate only at the load at ich it is tested and found accurate, as a change in load changes the tion between the belt speed fed to the integrator and the speed of belt passing over the scale. When the speed of the carrying strand 
(at a point adjacent to the scale) is fed into the integrator, the scribed error is eliminated.

The second feature is as simple in fact as the first but result: higher manufacturing cost. It involves the addition of a de that will automatically keep the belt carrying idlers on the scal exactly the same plane with the belt carrying idlers adjacent to scale. When the belt lies across the scale and a leveling devic not used, an error of 10 to 30 percent, depending on belt stiffnes relation to total load, must be balanced into the scale. If the was a good temperature compensated spring, belt tension woulc the only remaining variable force factor on the scale. However, belt is a very poor spring, and belt-tension effects must also be e] inated. Addition of the leveling device allows balancing of the $\mathrm{s}$ with or without the belt lying across the scale belt idlers with ide cal results. Thus the effects of belt spring and belt tension are, all practical purposes, eliminated by addition of a leveling device

We have found that incorporation of the two features explai enables us to build belt conveyor scales that will give a weigh accuracy for a given load that is just as accurate or even more ac rate than other approved methods of weighing the same loads.

For the reasons outlined, I believe that integrating belt conve scales are adequate for commercial use. Further, I respectfully gest that complete regulations regarding allowable tolerances, $\mathrm{n}$ imum runs, and standard tests be written in order that local weig and measures officials have some basis for approval of integrating conveyor scales.

Approximately 18 months ago we prepared a set of proposed in grating scale regulations. Only two or three people at this meet have seen that proposal. I know that several items in the prope should be altered but believe it is a starting point for making sc usable regulations.

(In answer to questions by Mr. Kerlin, Mr. Bradley explained that a pro test procedure is difficult to arrive at, that the conveyor idlers are kep alinement by the application of sensing devices, and that his term "commer accuracy" related to accuracy required of other commercial scales used in we ing similar loads.)

\section{TESTING OF VEHICLE TANK METERS}

BY W. A. KerLIn, Sealer of Weights and Measures, Alameda County, Califor

We have divided the problems of testing vehicle tank meters i three component parts, namely, Design, Location, and Operation Catibrating Equipment. Following is a general outline of these th main divisions:

\section{DESIGN OF PROVER}

1. Should meet all requirements of Handbook 45 and ASME-API Meter Code.

2. Size and proportion should be governed by rates of flow other physical conditions within the jurisdiction.

3. Must drain completely and uniformly.

4. Must not trap air. 
Outlet valve must not leak.

Must retain shape and capacity.

Interior should be protected against the elements.

Should be painted with a heat-reflecting color and paint.

\section{LOCATION OF PROVER}

Gravity provers should be in a pit so as to approximate filling ion conditions as to depth and venting.

Prover for power-operated meters can either be elevated or be in , depending upon local conditions.

Should be protected against direct sun.

\section{OPERATIONS (MAKING THE TEST, OR THE "HUMAN EQUATION")}

Must have well-trained personnel.

Inspection of installation for necessary accessories, air elimior, venting, etc.

Prover must be kept wet (tanks of this class are calibrated to iver). In this factor we have two liquid characteristics to coner; namely, volatility and viscosity.

Draining time must be constant; elapsed time between tests when ng volatile liquids must be reasonably constant. Temperature pact on draining time of the more viscous products such as No. 2 A No. 3 fuel oils must also be taken into consideration.

Testing of gravity meters.

Testing of power meters.

Evaporation.

Temperature change, or expansion and contraction.

is upon evaporation and temperature change that I base my harks before our general discussion. In corresponding with W. S. ssey concerning this discussion, he stated that many jurisdictions re encountering difficulties with inaccuracies in gravity meters. ntlemen, I doubt very much that the inaccuracies of which he speaks due to the meter itself, but I believe they are due to inaccuracies sing from our own methods of testing and our provers. I say this, as a champion of any meter manufacturer, but as a weights and asures official who has taken the time to isolate the inaccuracies. In connection with this particular problem, we have been doing ne research that indicates that a good many of these variations are to temperature changes not compensated for, plus the evaporation tor of a volatile testing fluid, such as gasoline. I will give some $t$ data that support these beliefs.

These tests were conducted in a test measure that met all requirents of the ASME-API Meter Code. In making the tests we used emovable fill pipe that extends to the bottom of the prover tank e fig. 2). This feature is also shown in the latest revision of the SME-API Meter Code. We have made tests both with and without s fill pipe and, as it is realized that most prover tanks do not have $\mathrm{s}$ feature, we are not presenting this to suggest that you add it to ur equipment. We do feel quite strongly, however, that the phemena should be given consideration in your testing work. Because 


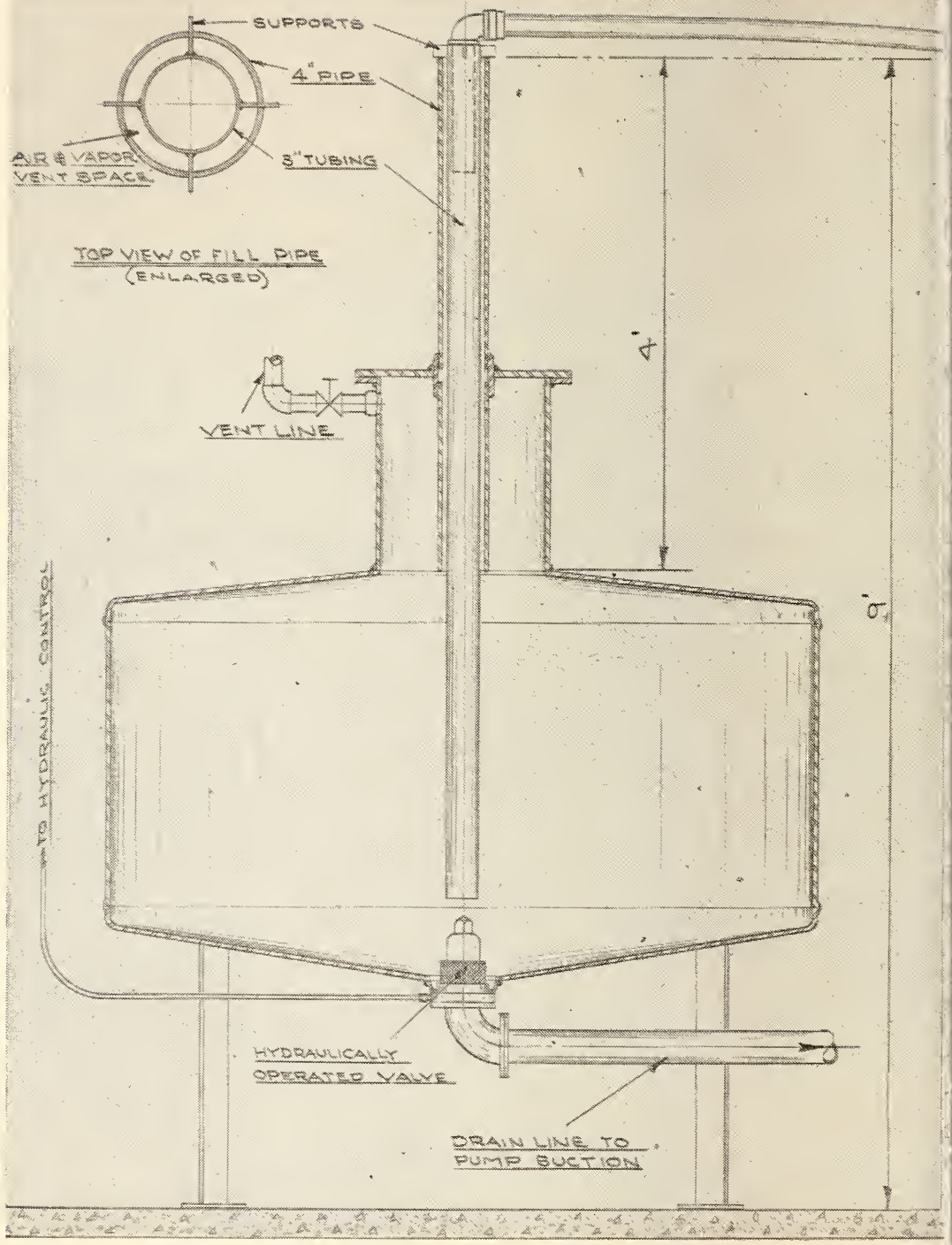

FIGURE 2. Meter prover for gravity meters. 
st provers do not have this feature, the following tests were made th both types:

TEst 1. (C'sing remorable fill pipe)

\begin{tabular}{|c|c|c|c|c|c|c|c|c|c|}
\hline \multirow{2}{*}{ Run } & \multirow{2}{*}{ Meter } & \multirow{2}{*}{ Size } & \multirow{2}{*}{ Type } & \multirow{2}{*}{$\begin{array}{l}\text { Rate of } \\
\text { flow }\end{array}$} & \multicolumn{2}{|c|}{$\begin{array}{c}\text { Temperature } \\
\text { at- }\end{array}$} & \multicolumn{2}{|c|}{ Prover- } & \multirow{2}{*}{$\begin{array}{l}\text { Test } \\
\text { type }\end{array}$} \\
\hline & & & & & Meter & Prover & $\begin{array}{l}\text { Read- } \\
\text { ing }\end{array}$ & $\begin{array}{l}\text { Capac- } \\
\text { ity }\end{array}$ & \\
\hline & $A$ & $\begin{array}{r}i n . \\
2 \\
2\end{array}$ & Rotary ... & $\begin{array}{c}g p m \\
60 \\
60\end{array}$ & $\begin{array}{c}\circ F . \\
62 \\
62\end{array}$ & $\begin{array}{l}\circ \mathrm{P} \\
62 \\
62\end{array}$ & $\begin{array}{c}c u \text { in. } \\
-2 \\
-2\end{array}$ & $\begin{array}{l}\text { gal. } \\
100 \\
100\end{array}$ & $\begin{array}{c}\text { Normal. } \\
\text { Do. }\end{array}$ \\
\hline
\end{tabular}

TEST 2. (Using open neck of prover and fill pipe removed; otherwise, same conditions existing, and same meter)

\begin{tabular}{|l|l|l|l|l|l|l|l|l|l}
\hline 1 & & & & & \\
\hline 2 & A & 2 & Rotary-n....... & 60 & 62 & 62 & $\mathbf{- 4 4}$ & 100 & Normal. \\
\hline
\end{tabular}

TEST 3. (Using open neck of prover and fill pipe removed; prover cooled by water spray to introduce temperature change; all other conditions equal, and same meter)

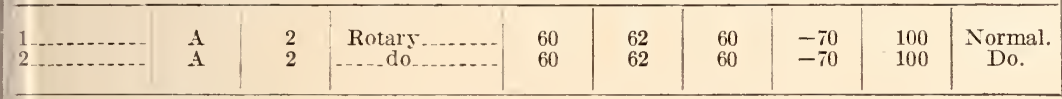

As can readily be seen from an analysis of the three sets of tests sntioned above, there was an eraporation of $42 \mathrm{cu}$ in. on the second of tests. This same evaporation was present on the third set of its, plus a 28-cu in. rariation for temperature differential. Deduct$x$ the $28 \mathrm{cu}$ in. for temperature, we find the results of tests 2 and 3 e the same within 2 cu in.

Of course, there were many, many tests of this type made to estab$h$, beyond a doubt, that the data presented herein is correct; not ly were many tests run, but sereral different makes of meters were ed. In the tests of which I speak, there were actual meter rariions, but these did not varr more than $5 \mathrm{cu}$. in. The actual meter riations were negligible when compared to the rariations caused by mperature and eraporation.

I was requested also to give information and data concerning gravity eter tests made from a full compartment and tests made from a mpartment with just slightly more than enough fluid to complete e tests.

These tests are standard procedures in our testing plant and are of e "normal test" type. As you will note from the tests shown below, ere is a slight rariation in some cases, probably due to increased ippage at slower speeds:

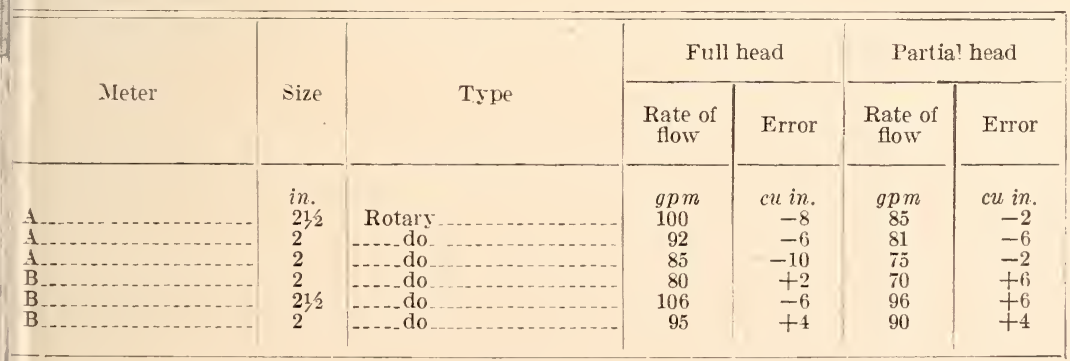


We have found very little variation in tests of this type, and I g them to you only for purposes of discussion.

We now come to power meters and find we have the same $t$ variables, plus one or two more. Let us again return to ideal con tions and note the results.

Test 1. (Using removable fill pipe; test measures are on overhead platform, seven feet above ground)

\begin{tabular}{|c|c|c|c|c|c|c|c|c|c|c|}
\hline \multirow{2}{*}{ Run } & \multirow{2}{*}{ Meter } & \multirow{2}{*}{ Size } & \multirow{2}{*}{ Type } & \multirow{2}{*}{$\begin{array}{l}\text { Rate of } \\
\text { flow }\end{array}$} & \multicolumn{2}{|c|}{$\begin{array}{l}\text { Temperature } \\
\text { at }-\end{array}$} & \multicolumn{2}{|c|}{ Prover- } & \multirow{2}{*}{ Test type } & \multirow{2}{*}{ Moto } \\
\hline & & & & & Meter & Prover & $\begin{array}{l}\text { Read- } \\
\text { ing }\end{array}$ & $\begin{array}{c}\text { Capac- } \\
\text { ity }\end{array}$ & & \\
\hline $1 \ldots$ & $\underset{B}{B}$ & $\begin{array}{l}\text { in. } \\
11 / 2 \\
11 / 2\end{array}$ & $\begin{array}{l}\text { Rotary } \\
\text { - }\end{array}$ & $\begin{array}{c}\text { gpm } \\
32 \\
32\end{array}$ & $\begin{array}{l}\circ F \\
64 \\
64\end{array}$ & $\begin{array}{l}\circ F \\
64 \\
64\end{array}$ & $\begin{array}{r}\text { in. } u \text {. } \\
+4 \\
+4\end{array}$ & $\begin{array}{l}g a l \\
50 \\
50\end{array}$ & Normal_... & $\begin{array}{r}r p m \\
750 \\
750\end{array}$ \\
\hline
\end{tabular}

Test 2. (Using open neck of prover; no tube; same conditions; otherwise, same meter)

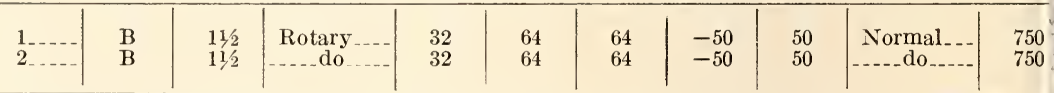

Test 3. (Motor speed the same and nozzle controlled; ideal conditions, using removable tube)

\begin{tabular}{l|l|l|l|l|l|l|l|l|l|l}
\hline $1 \ldots$ & B & $11 / 2$ & Rotary _.. & 22 & 64 & 64 & -14 & 50 & Slow .... & 750 \\
\hline
\end{tabular}

Test 4. (Same unit used; ideal conditions; slow speed test using motor eontrol)

\begin{tabular}{|c|c|c|c|c|c|c|c|c|c|c|}
\hline $1 \ldots$ & B & 132 & Rotary & 24 & 64 & 64 & -2 & 50 & Slow $\ldots . .$. & 450 \\
\hline \multicolumn{11}{|c|}{ Test 5 . (Same operating conditions as test 2) } \\
\hline 1. & B & $11 / 2$ & $\mathrm{R}) \operatorname{tar} y$ & 32 & 64 & 64 & -82 & 50 & Normal ... & 750 \\
\hline
\end{tabular}

As can be seen, the evaporation factor is still present but increase probably due to higher nozzle velocity.

We will eliminate the temperature test, for the sake of brevity, $f$ we know the results of that one.

The added variables on power meters depend upon whether $t$ ] speed is controlled by nozzle or by motor. Let us look at a "slow tes taken on the same unit as tests 1 and 2 .

From the illustrations given we can see that the motor-controlle test gires the more accurate result. Although neither test 3 nor 4 out of tolerance in this case, we have found aggravated condition existing on many vehicles, and it is a variable that must be taken in consideration.

One more test, in which I am sure you will be interested, is the testil of a power meter using a prover located below ground level. F, test 5 we used the same unit.

For test 2, using the overhead 50-gal. measure, the error was min $50 \mathrm{cu}$ in. In the pit test measure of $50 \mathrm{gal}$, the error should be t] same. This, however, is not true. With a vaporization error preser the length of drop of the liquid is also a factor; therefore, we have compound error produced.

It is my understanding that considerable difficulty has been exper enced on power meters with or without predetermined shut-off valve 
e difficulty seems to be a "creep" in the meter due to the difference veen the "operating" pressure and the "relaxed" pressure. This ep may be caused by "hose stretch." In fact, extreme caution must used in the testing of power meters to insure that tests are started d stopped with the same hose condition. That is, if the test is begun th a pressurized hose, it must be terminated with a pressurized hose. less this procedure is followed there will be a slight error, depends upon the type and size of hose used. A spring-loaded backessure valve in the line at the entrance to the hose reel will minimize s condition to a great extent. This valve does double-duty because :educes hose stretch and also helps the air eliminator at the tailing-off int.

Creep should not be present in equipment with predetermined shutvalves unless the valve is leaking: There are other phenomena esent, however, with this type of device.

Many of you will remember the heated arguments on the floor of e 34th National Conference to reduce, or cut, the tolerances on olesale liquid-measuring devices as recommended by the Committee Specifications and Tolerances. While I do not wish to take issue th the action of the Conference at that time, I do wish to point out at actually the Acceptance Tolerance was increased on "Special sts" and decreased by only $121 / 2 \mathrm{cu}$ in. on a 100-gal. normal test.

My point in bringing this to your attention is not to campaign for other reduction in tolerance but to point out that a temperature ange in gasoline of only $1^{\circ} \mathrm{F}$. from the truck compartment to the over will result in an expansion or contraction of a sufficient amount nullify this reduction in tolerance. In order to even record this Auction in tolerance, the "calibration plant" or "prover" must be eated as a laboratory by weights and measures officials and not just cest can.

The test results noted indicate that, before any further reduction tolerances can be seriously considered, we must take into considera, on the two variables, evaporation and temperature change.

(After the presentation of his paper, Mr. Kerlin answered questions from the for. These questions dealt with items brought out in the paper, and Mr. rlin elaborated on such items.)

(The Conference was adjourned, to reconvene on Friday, May 23, 1952, at 30 a. m.)

\section{XTH SESSION-MORNING OF FRIDAY, MAY 23, 1952}

\section{(J. F. True, Vice President, and A. V. Astin, President, presiding)}

\section{DR. A. V. ASTIIN PRESENTED}

(Dr. A. V. Astin, Director of the National Bureau of Standards, and newly cted President of the National Conference on Weights and Measures, was esented to the Conference by the Chairman. Dr. Astin made the following marks and committee appointments. He continued to preside as chairman til the completion of the report of the Committee on Methods of Sale of ommodities).

Dr. Astin. I appreciate very much this honor you have conferred pon me, and I hope that I will be able to put in a fair amount of time problems of interest to the Conference during the coming year.

I know that, with Mr. Bussey available to work with, things will get one, and you can be assured that he will be given my full support in yything he wants to do in connection with the affairs of this onference. 


\section{APPOINTMENT OF STANDING COMMITTEES}

It is appropriate at this time for me to announce appointmes to the several Standing Committees of the Conference.

\section{COMMITTEE ON SPEGIFICATIONS AND TOLERANCES}

I appoint Rollin E. Meek, State of Indiana, to a five-year te to succeed Nalls Berryman, State of Florida, whose term is expirin

\section{COMMITTEE ON METHODS OF SALE OF COMMODITIES}

I appoint George H. Leithauser, City of Baltimore, Maryland, a five-year term to succeed Russell Ackerman, City of Minneapo. Minnesota, whose term is expiring; and Irvine M. Levy, City of Cl cago, Illinois, for one year to complete the term of Llewellyn R. Rop City of Seattle, Washington, who has resigned because of a change positions with the City of Seattle.

\section{COMMITTEE ON LEGISLATION}

I appoint Miles A. Nelson, State of Michigan, to a five-year ter to succeed C. H. Oakley, formerly of the State of Wyoming, now employee of the National Bureau of Standards, whose term is $\epsilon$ piring; and Donald M. Turnbull, City of Seattle, Washington, $f$ three years to complete the term of Rollin E. Meek, State of Indial who has resigned to accept appointment on another Conferer Committee.

\section{COMMITTEE ON EDUCATION}

I appoint Joseph F. Blickley, State of Pennsylvania, to a five-ye term to succeed Robert K. Slough, City of Akron, Ohio, whose term expiring.

\section{COMMITTEE ON TRADING BY WEIGHT}

I appoint A. J. Mayer, State of Louisiana, to a five-year term succeed Erling Hansen, State of Minnesota, whose term is expirin

\section{CONFERENCE CHAPLAIN}

To serve as Conference Chaplain for the 38th National Conferen I reappoint $\mathrm{R}$. W. Searles of Medina County, Ohio.

\section{REPORT OF COMMITTEE ON METHODS OF SALE OF COMMODITII PRESENTED BY JOSEPH G. ROGERS, CHAIRMAN}

(Continued from page 64 .)

We will now call on Mr. Rogers, of New Jersey, to continue the rep of the Committee on Methods of Sale of Commodities.

Mr. Rogens : The items left over from yesterday are 9, 10, and 11 the Report of the Committee.

9. Preheated Fuel Oits.-This item was referred to your Committ by vote of the 36th National Conference for recommendation as proper method of sale for such oils. While the Committee has devot some study to the question it has not, up to the time of preparing tl report, reached definite conclusions to submit to the Conference, a indulgence is, therefore, asked for continuation of our research on tl subject.

10. Homogenized Concentrated Milk.-Action was deferred on $t$ Committee's recommendation covering this subject which appeared 
m No. 2 in our report to the last annual Conference and was referred $\mathrm{k}$ to Committee for further study.

To further conclusions have been reached than those originally preted. The dairy interests contemplating the production of such milk $\mathrm{m}$ to have lost interest and there appears to have been no intensity in ceeding with further developments. Under the circumstances this mmittee feels that further consideration of this item can be pended pending the necessity for definite action.

11. Meats and Poultry in Plastic Wrappings and Casings.-For the rpose of clarification this Committee reopens this topic which apired as item 3 in our report to the 36 th National Conference. The ommendation it contained was adopted at that time. It reads as lows :

Meats and Poultry in Plastic Wrappings and Casings.-Shall be exempt rom net quantity declarations at packing sources and shall be sold on the asis of actual net weight at time of sale; provided that each item of meat ir poultry so wrapped or contained shall be plainly and conspicuously marked vith the legend: "To Be Weighed At Time of Sale", and, where the weight of he wrapping or casing exceeds $1 / 8$ ounce, the tare weight shall be plainly and conspicuously marked for deduction to determine the net weight.

The Southern Weights and Measures Association through an action its Committee on Methods of Sale of Commodities subsequently filed objection emanating from their Conference session at Richmond, rginia, on November 7th, 1951. It was referred in report form, inrporating other items, to our Committee through the Office of eights and Measures of the National Bureau of Standards. We ote from the said report:

3. Meat, Poultry, Fish and Cheese in Plastic Wrappings and Casings.This Committee feels that commodities of variable weights in package form and those commodities that because of their method of processing prior to sale do not lend themselves to consistent quantity declarations when in package form should be sold from bulk and should not be exempt from the requirement of net weight markings on individual consumer packages. This legend-"To be weighed at time of sale," is contrary to the Model Law which requires that all commodities in package form be labeled as to weight, measure or numerical count. Experience and tests have shown that some packages of fish and cheese, even though marked with the legend, "To be weighed at time of sale," are not being weighed by some merchants when a retail sale of these commodities is made.

Therefore, your Committee is of the opinion that this recommendaon is inconsistent with the Model Law and should be referred or nended so as to be consistent.

The Committee of the Southern Weights and Measures Association pears to have amplified the items under this heading in their report id have added fish and cheese which the adopted recommendation d not include.

Dealing with the points of contention in their order as raised in the emurrer of the Southeln WVeights and Measures Association, we ould first mention that our reasons behind the recommendation were 1lly given when it was offered to the last Conference for consideraon. Those reasons we consider to be as logical and sound now as iey were when the Conference in its wisdom saw fit to adopt what we roposed.

The Committee of the Southern Association now proposes that those mmodities which because of their method of processing prior to sale not lend themselves to consistent quantity declarations when in ckage form should be sold from bulk and should not be exempt from 
the requirement of net weight markings on individual consumer pa ages. The catch in this is the proposed sale from bulk. This wo presuppose that we would require the packing enterprises putting the types of commodities involved in this controversy, to change th methods of production and revert to packaging in barrels, tubs, $p$ and crocks as employed in the era before the age in which we are $n$ living, and when sale from bulk was the rule and not the excepti It is not difficult to visualize the reaction that would set in were now to attempt such restriction. Whether we like it or not, we $m$ realize that the individual consumer package is here to stay, as we aware that production methods along this line are increasing and decreasing.

The Bureau of Animal Industry of the Federal Government ] already taken cognizance of methods now inherent in packaging sential foods and has ruled that meats in casings are exempt fr marking requirements. In this they probably were influenced by same reasons as those upon which the adoption of our recommendat was based. Our action is, therefore, not without precedent. In de ing with the matter of exemptions, however, we incorporated a $p$ tective factor by the stipulation that packages entitled to quant marking concessions should bear the legend "To Be Weighed At Ti of Sale" to place merchants under notice as to their obligation vending such packages. As to the effect of such legend and the servation offered that packages so marked "are not being weigh by some merchants when a retail sale of these commodities is mad the enforcement of the instructions contained in the legend natura becomes the obligation of local supervision at retail outlets. Its , fectiveness would, of course, not be self-sufficient without this.

On the question of the recommendation being contrary to the Moc Law requiring packaged commodities to be labeled as to weight, me: ure or numerical count, we agree that it is a departure not only frc this but from existing laws in State jurisdictions, but we must at $t$ same time consider that these statutes were placed on the books lo before the packaging situation has become what it is today, with all technical and troublesome ramifications and problems. With the $c$ velopment of this situation it was natural that ideas for new metho and processes would be conceived and born. They are looked up in the light of progress. The challenges they offer call for readju: ments of regulatory affairs if we are not to obstruct such progre which represents America at work.

Your Committee is further cognizant that the contents of its recor mendation represents new thought in relation to marking regulatio under net weight container laws. However, it is a thought influene and necessitated by evolutionary trends in the packing industry, whi appear to justify a modification of marking requirements in certa circumstances as relating to the commodities entailed in this issue.

The sole purpose of our recommendation on this issue is to establi a means by which the consumer will pay for only what he gets. At t] same time it sets up a procedure with which all engaged in packir and trade pursuits can readily conform without detriment to consum welfare. The consumer in fact benefits by the principles of this $r$ commendation as it has the effect of bringing the packaged produ back to the days when purchases were weighed at the butcher blor or store counter and the buyer was not saddled with shrinkage lo 
ich, we believe all agree, is the most objectionable feature in relato packaging.

is the result of our review and reconsideration of all factors inred in this issue, your Committee is of the opinion that the recomdation as adopted by the 36th National Conference should stand originally constituted without amendment, and we so recommend. IR. KENNEDY : I feel that this recommendation is entirely too broad. now have chickens in plastic bags. I presume you call them stic wrappers. They are susceptible of being marked with the ght. I can see no reason to eliminate such items from a prepacked nter. WVe must seek, and we must have, the cooperation of the rchants. They want to cooperate. But you are throwing obstacles their way whereby they cannot cooperate. I think the recomndation of last year should be reviewed and rewritten.

[R. RoGers: This will have no effect on the prepacking situation. e man that uses those methods must price, mark, and weigh his kages. This exemption is at the processing source. It is to cover kes ns especially subject to shrinkage. The merchant sometimes finds pronself in trouble. He buys in good faith and sees that the package aproperly marked. That marking is not good because there has in shrinkage during the marketing process.

ir. KENNEDy: Are you opposed to the inclusion of fish and cheese, included in the Southern Association recommendation?

H. [R. Rogers: We were trying to cover two items only. We thought m most essential. We want to pursue it further. There are a imber of items of cheese that should be under the same recommendan. There are types of cheese today which are put up in tin containwith holes. This cheese is in package form. You put a marking it today, and in several hours that marking is no longer correct. ey must weigh it when it is sold. Many commodities are handled in same manner.

Mr. Kennedy: You did not include cheese.

Arr. Rogers: No, we did not. We were trying to comprehend the ms sold in the package in which they are processed.

WR. KENNEDY: There are some fish that are processed at the point of gin.

IIR. Rogers: The packers are willing to mark packages of fish, but marking is not valid because of shrinkage.

Ir. KENNEDY: The Southern Association recommended fish and sese. If you are going along with them, why not include fish and rese?

Mr. Rogers: We are certainly not objecting at all to the inclusion those items, if you gentlemen want to do it.

IR. KENNEDY: There is no recommendation to that effect.

MR. HART: I am Secretary of the Gloucester Fisheries Association, ucester, Massachusetts. We are a substantial fishing port, $, 000,000$ pounds a year. Of that total, 90 percent of the fish is eted and frozen. Within the past 4 to 5 years we have developed so-called 1-pound pack. Probably from 20 to 25 percent of our al pack now is in 1-pound packages. The bulk of our fish is put up what we call 5- and 10-pound cartons. They contain in the case of 5 -pound cartons five packages of fish. They will take a 5-pound , fill it with fillets, and allow a tolerance possibly of $21 / 2$ or 3 ounces. packages are wrapped. The weight is indicated on the outside he carton. 
The same principle applies on the 10-pound pack. We han something like $65,000,000$ pounds of fillets a year. It would be phcally impossible to weigh your cellophane wrapped fillets at the ti of packing. The are using inserts in the carton. The insert res "Reweigh at time of sale."

Mr. McBride: I wish to offer an amendment to the original moti I believe this is consistent with Mr. Kennedy's remarks, and I m that the subjects "fish and cheese" be included with the commodi that the committee has enumerated.

Cilairman Astin: Mr. Rogers indicates that he will accept $t$ amendment.

(The motion was seconded and adopted by the Conference.)

Item 11, as amended and adopted by the Conference reads as follows:

Meats, Poultry, Fish, and Cheese in Plastic Wrappings and Casings.Shall be exempt from net quantity declarations at packing sources an shall be sold on the basis of actual net weight at time of sale, provided the each item of meat or poultry so wrapped or contained shall be plainly an conspicuously marked with the legend: "To Be Weighed at Time of Sale and, where the weight of the wrapping or casing exceeds $1 / 8$ ounce, the tar weight shall be plainly and conspicuously marked for deduction to determin the net weight.

(The report of the Committee on Methods of Sale of Commodities was adoI as amended.)

\section{REPORT OF THE COMMITTEE ON SPECIFICATIONS AND TOLERANC PRESENTED BY J. P. MCBRIDE, CHAIRMAN}

The tentative report of the Committee has been in the hands Conference members, and representatives of industry, for some ti

It was stated in this report that the committee would be glad receive suggestions and to afford opportunity of hearing on the $\mathrm{m}$ ters treated in the report. Sunday was devoted to hearing interes parties, and, as a result of these hearings, your committee is offer for your consideration the final report. I shall present for $y$ consideration and action, the tentative report of the committee amended by the final report.

Your Committee has had two interim meetings with the ice cre and carton manufacturing industries and one with the scale indust Correspondence has been carried on with other affected indust and with Conference members in relation to the various matti This report, therefore, represents Committee conclusions in relat to matters referred to it by the 36th National Conference and to th coming before it from other sources.

TENTATIVE CODE FOR PRE-PACKAGED-ICE-CREAM MEASURE-CONTAINERS

At the 36th Conference, this code was first submitted and tentativ adopted.

The last sentence of specification S.2.1 Capacitr Pornt reads follows:

... A pre-packaged-ice-cream measure-container shall contain its ind cated capacity without apparent distortion from its designed regular shape

The phraseology "without apparent distortion" is conceded to equivocal language and conducive to vacillating procedure wh would result in lack of uniformity.

In this type of measure-container, cognizance must be taken of fact that it is susceptible to distortion, and that such distortion beg when the measure-container is assembled or shaped so as to rece 
ice cream. Further distortion occurs in the filling and hardening he product. A measure-container equal to the calculated capacity, efore, presents a factor of excess quantity which becomes a concern he weights and measures official, as it is his duty to protect the dor as well as the consumer. It is obvious, therefore, that to require ntainer to be of dimensions equal to its calculated capacity, though offers an easy method of test, would not be in keeping with the gation of the weights and measures official to preserve the equities ween all parties.

Ine answer to the distortion problem might be to require the use board of sufficient quality and thickness, so as to maintain rigidity. $\mathrm{s}$ would involve specifications on quality of material, and it is not purpose of our code to enter this field. It could also be offered t a supporting frame should be employed when the measuretainer is being filled. Inasmuch as these are single-use containers, economic factors of cost of the container and cost of production er into consideration, as these costs would be reflected to the sumer.

third method might be to allow the use of a container of dimenus less than the indicated capacity, and anticipate the yield to be $h$ as to provide for such indicated capacity. 'This, too, would not good weights and measures practice, as there would be a variable, ending on quality and thickness of board, as well as on shape and ign of the carton, and method of fill and handling. It would leave $\mathrm{n}$ to the unscrupulous the advantage of controlling the fill with imum distortion, and thus giving short measure.

our Committee has spent considerable time during the year on its initiative and in cooperation with the ice cream and carton ustries, as was its promise in the report to the 36th Conference. were seeking to develop a uniform test procedure and a testing lium to meet this problem.

$\mathrm{n}$ its final analysis, the question is as to whether a square, rectanguor other flat-sided container could be acceptable if its calculated ical content was somewhat less than actual (or indicated) cubical tent, provided the ice cream packed in such container was, in fact, al to or in excess of the indicated capacity.

rumerous experiments were conducted, and various tests were emyed, to prove the point that the required volume could be accomhed in a measure-container of these characteristics. This was isfactorily established, but in some instances the methods employed e involved and somewhat complicated. Furthermore, practical faties for some of these tests would not be readily available to weights I measures officials for field tests. All parties were agreed that ter is the most readily available and most satisfactory testing dium.

Ve finally resolved the question of distortion to be confined to the called normal shape which would result solely from the assembly shaping of the container in form to receive the ice cream. It uld be the obligation of the ice cream manufacturer to fill these tainers in a manner so as to follow the normal design and shape he container as assembled. Moreover, the manufacturer would not apt to fill beyond this conformation, since this would cause a loss product to him.

[This method of test would require that the measure-container be ted with support. The problem then was to develop a holding or 
supporting device, for containers larger than one quart, which wc be readily available, and into which the assembled empty carton cc be placed, so that this normal distortion on all four sides would re the supports and be thus confined when the carton was tested capacity with water.

This method, in the opinion of the Committee, offers the best most practical means of resolving the difference between the so-ca calculated cubical content and the actual volumetric content. method requires that further distortion shall be controlled by the cream manufacturer-his guide being to follow the intended des and shape of the carton. The method also follows the test proced outlined in National Bureau of Standards Handbook 45 for meas containers.

Your Committee, therefore, recommends that this code be amen as follows:

Amend S.1. by changing the side title "CAPaCities" to "Units".

Amend S.2.1. to read as follows:

S.2.1. CAPACITy PoInT.-The capacity of a pre-packaged-ice-cream meas container shall be sharply defined by (a) the top edge, (b) a graduation I the top edge, or (c) the lowest portion of a shoulder, cap seat, lid seat, or in tation near the top edge, of the container. A graduation or indentation $s$ extend at least half-way around the circumference or across two opposite $s$ of the container.

Add a new paragraph S.2.2., as follows:

S.2.2. SнAPE.-A pre-packaged-ice-cream measure-container shall be desig as some regular geometrical shape, and its capacity shall be determined witl distortion from its normal assembled shape.

Add a new section, N. NOTES, to read as follows:

N. NOTES.

N.1. Testing Procedures for Water Test.

N.1.1. Preparation of Knocked-Down Container.-A knocked-down packaged-ice-cream measure-container shall be properly assembled, tape shal applied to the outside of the bottom of the container, if necessary, to main its normal assembled shape, and melted wax shall be applied to the inside the container to the extent necessary to make the container water tight. treme care should be exercised to avoid applying more wax than necessary order that the capacity of the container may not be significantly reduced.)

N.1.2. Prevention of Distortion of Flat-Sided Container.-A pre-packa ice-cream measure-container having flat sides shall be, if necessary, so restrai before the actual test is begun that its sides will not bulge when it is filled v water. For containers having capacities of 1 liquid quart or less, this can accomplished by applying a metal plate or a piece of heavy cardboard to e side of the container. These pieces shall be only slightly smaller than sides to which they are applied. They can be held securely in place by me of rubber bands, cord, or tape. Larger containers shall be supported by a ri restraining form having a design symmetrical with the container being tes This form shall support against distortion not less than the entire area of central two-thirds of each side panel of the container, measured from botton top. The inside width dimension of any side panel of the restraining $f($ shall be $1 / 16$ inch greater than the corresponding outside dimension of the c tainer. (The outside width dimension of any side panel of the container sl be established by adding to the inner side center-of-score to center-of-sc dimension two thicknesses of the board used, and the sum thus obtained sl be rounded off to the nearest $1 / 64$ inch.)

It is the understanding of your Committee that the ice cream a carton industries will proceed immediately, after the final adopt: of this code, to establish, if possible, one size and shape for $1 / 2$ gall flat-sided ice-cream measure-containers. 
Vith the adoption of the above amendments, your Committee mmends the final adoption of the code for pre-packaged-ice-cream sure-containers.

ested Tentative Test Procedure for Volumetric Measuring of Pre-packaged-Ice-Cream Carton in flat.

Measure-Containers, see figures $3,4,5$, and 6

and c. Folding back carton to break all scores. This tends to re up the package and prevent propelling.

Block of wood or box made about $1 / 32$ inch short of inside dimenis of carton.

Place carton over block and lock bottom.

Apply pressure to carton bottom over form so that the full flap lie flush and square. Holding this down tightly apply tape (any zen-food locker tape will do nicely) to the center edges of carton hown in figure $3, \mathrm{f}$.

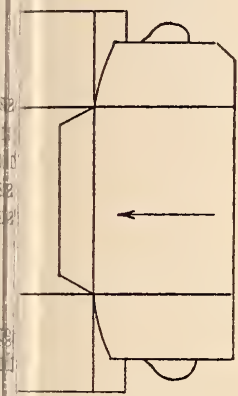

a

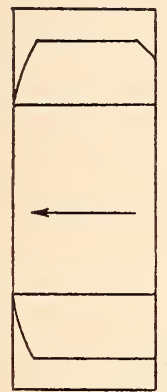

b

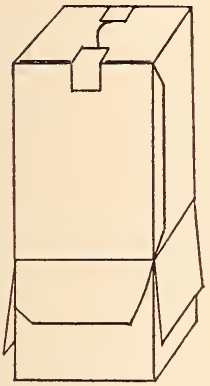

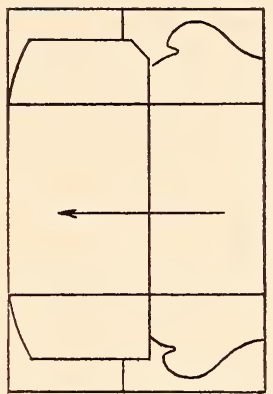

C

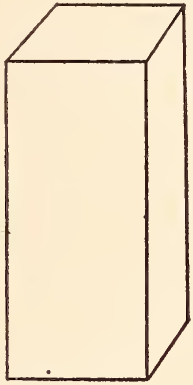

d $f$

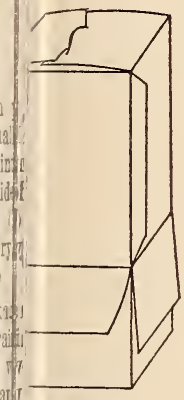

e

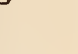

1
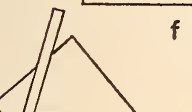
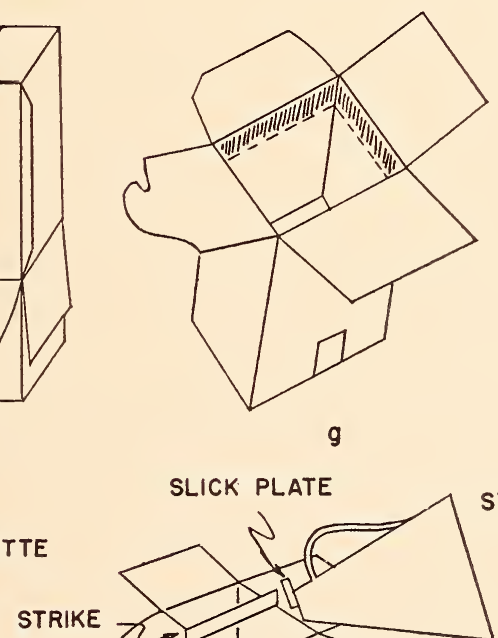

9

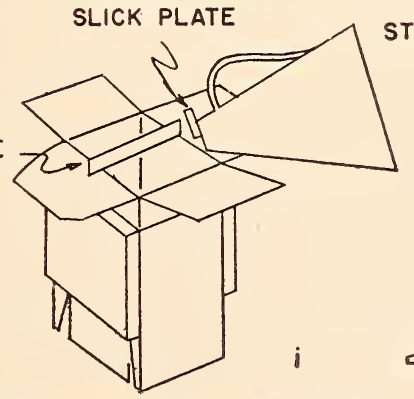

STD. MEASURE

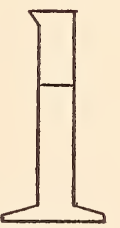

Figure 3. Pre-packaged-ice-cream measure-container ( $1 / 2$ gallon).

Preparation for test. 


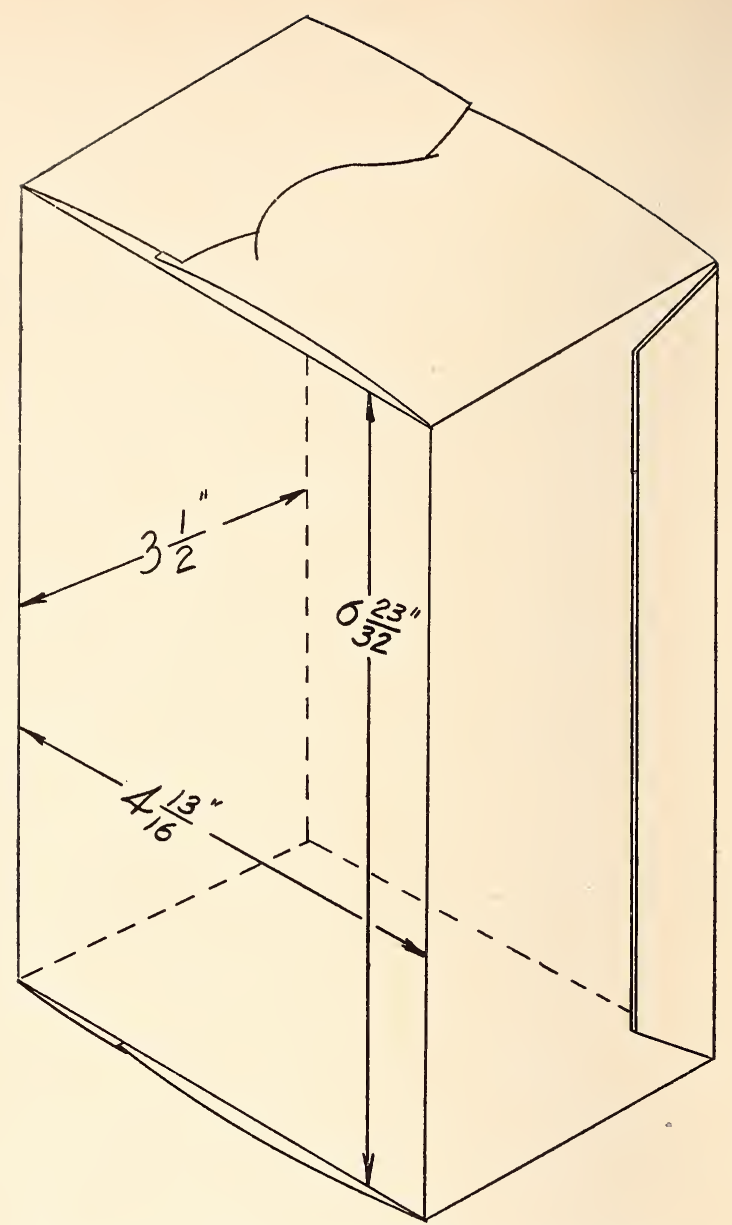

Figure 4. Proposed standard 1/2-gallon carton.

$413 / 16$ by $31 / 2$ by $623 / 32$ inches. Calculated cubical content 113.1689 cubic inches. Act volumetric content by tentative test method 115.622 cubic inches outside seal, 115. cubic inches inside seal.

g. A detergent or liquid soap is wiped on the top sides of the cart to break the surface tension of the water used in measuring carton.

h. Using a 1.1-ml pipette (or a pipette graduated so that a knor volume of wax may be measured) deposit all the wax in the corner th hinges the full flap (bottom flap). The carton at this time is held an angle and the carton rotated to let the wax run along the cut edg of the bottom flap and back to the original starting point. Tr should give a tight seal to the bottom.

It is recommended that a mixture of 20 percent of amorphous w: and 80 percent of regular paraffin be used.

i. The carton is now ready for volumetric measuring, and the on caution suggested is that in releasing the water from the standa: measure to the carton, that it should not be done too quickly. If $\mathrm{r}$ leased too quickly, the seal is most likely to break. Fill to the strik using additional water from a graduate holding a known volume water. If the water reaches the strike before all water is drain from the standard measure, pour remaining water into graduate. 


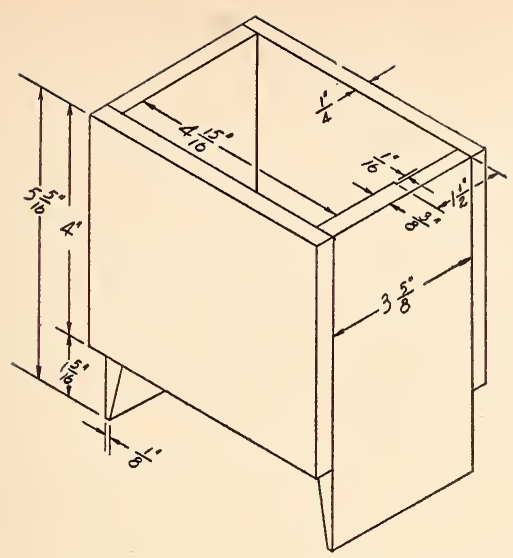

Figure 5. Proposed restraining form for volumetric measure $1 / 2$ gallon.

Carton based on center-of-score dimension. Plus 2 stock thickness $+1 / 16$ inch.

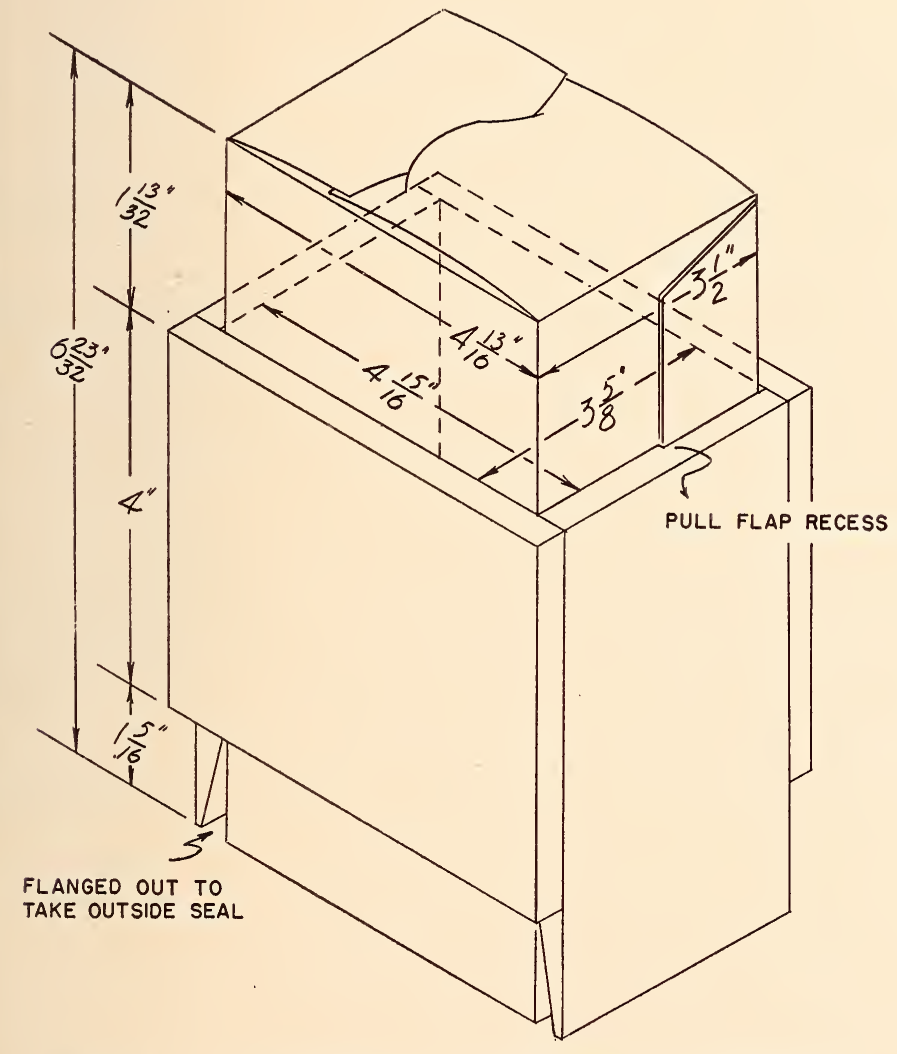

FIGTRE 6. Determination of restraining form dimensions.

4 ide dimension of form is based on center-of-score to center-of-score measurement, plus two thickness of stock plus $1 / 16$ inch.

$3.5+.052+.0625=3.6145$, or $35 \%$ inches.

$4.8125+.052+.0625=4.927$, or $415 / 16$, inches. 


\section{TENTATIVE GODE FOR CORDAGE-MEASURING DEVIGES}

\section{Amend S.2.2., Indicating Means, to read as follows:}

S.2.2. Indicating Means.-This shall be so constructed that the proper met of reading the indications will be readily apparent. The motion of the $n$ sensitive indicating element shall be continuous as material being meast is passed through the device; the motion of other indicating elements may intermittent. If the most sensitive element of the indicating system util an indicator and graduations, the relative movement of these parts correspe ing to a measurement of 1 foot shall be not less than $1 / 4$ inch. If separate ments are utilized to tally feet, tens of feet, hundreds of feet, and so on, comp revolutions of each such element shall be accurately and definitely tallied, and such elements shall be accurately synchronized. The indicating elements s. be readily returnable to a definite zero indication.

Amend Tolerance Table 1 to read as follows:

TABLE 1.-Maintenance Tolerances for Cordage-Measuring Devices

\begin{tabular}{|c|c|c|}
\hline \multirow{2}{*}{ Indication of device } & \multicolumn{2}{|c|}{ Tolerance } \\
\hline & On over registration & On under registratio \\
\hline $\begin{array}{l}0 \text { to } 20 \text {, incl } \\
21 \text { to } 30 \text {, incl } \\
31 \text { to } 40 \text {, incl } \\
41 \text { to } 50 \text {, incl } \\
\text { Over } 50\end{array}$ & $\begin{array}{c}\text { Inches } \\
1 \\
11 \frac{1}{2} \\
2 \\
21 / 2 \\
\text { Add } 1 \text { inch per indi- } \\
\text { cated } 50 \text { feet. }\end{array}$ & $\begin{array}{c}\text { Inches } \\
2 \\
3 \\
4 \\
5 \\
\text { Add } 2 \text { inches rer } \\
\text { indicated } 50 \text { feet. }\end{array}$ \\
\hline
\end{tabular}

The reason for the first amendment is that the original wording S.2.2 is more severe than like provisions in other similar codes. Y, Committee feels that the relative low cost per unit of the materi measured by these devices does not justify this extreme degree of $\mathrm{c}_{1}$ trol by weights and measures officials. Furthermore, so far as Committee has been advised, no manufacturer in the United Sta has yet produced a device which will meet the original requiremer Your Committee believes that this proposal is reasonable and pror

The second amendment has been found necessary for the reason $t]$ these devices must perform both forward and backward. This cau an extreme amount of backlash in the gears, etc. Therefore, a lar: tolerance to take care of the initial error is required. Also, m deliveries through these devices will exceed 20 feet.

With the adoption of the above amendments, your Committee reco mends the final adoption of the code for cordage-measuring devic 


\section{LIQUEFIED PETROLEUM GAS MEASURING EQUIPMENT}

During the 36th National Conference on Weights and Measures, ras suggested that the Committee on Specifications and Tolerances udy and make recommendations for specifications, tolerances, and ulations covering measuring equipment for liquefied petroleum es. At that time it was indicated that substantial assistance would volunteered and rendered by the various industry organizations olved. Since such assistance was not forthcoming, and since the nmittee has no facilities at its disposal for the necessary research investigation, your Committee is unable to offer recommendans at this time. Your Committee hopes that further developments esting equipment and procedures for liquefied petroleum gas meas$\mathrm{ng}$ devices will be forthcoming in the near future. The cooperation $\mathrm{l}$ assistance of industry is invited.

ZOMMENDATIONS OF THE SOUTHERN WEIGHTS AND MEASURES ASSOCIATION

The Southern Weights and Measures Association, at their Novem1951, Annual Conference voted to submit to the National nference Committee on Specifications and Tolerances four recomndations, as follows:

secommendation 1.- That the conference again call upon the National Conence to eliminate from the scale tolerances the excess tolerance permitted scales with stabilized load-receiving elements.

cecommendation 2.- That this conference recommend to the National Conence that serious consideration be given to the development of separate codes tolerances for each of the following: 1, bulk plant and terminal meters; ank truck meters under pressure; and 3, gravity meters.

'Secommendation 3.-That this conference request the National Conference ;ive study to revising the tolerances for Retail Liquid Measuring Devices, and $t$ tolerances, as indicated below, be inserted in Table 1, in lieu of the present rances, provided, however, that this amendment shall not apply to pumps Ii) ing delivery hoses in excess of 15 feet.

gallons
$1 / 2$ or less
1
2
3
4
5

Over 5 cubic inches

2
3
4
5
5
5

Add 1 cubic inch per indicated gallon.

Recommendation 4.-That this conference request the National Conference eiminate in paragraph R. 5. of the Scale Regulations, the word "retail." 


\section{ReCOMMENDATION 1}

In connection with Recommendation 1, the Southern Associat; proposed to the National Conference last year that the special Sh Test tolerances allowed on small-capacity scales, with stabiliz load-receiving elements, as provided in T.1.1.2. be eliminated; the $\mathrm{r}$ son for the recommendation being that strict adherence to the T.1. tolerances would lead to inconsistent results. In given situations scale with a zero error on center loading would be condemned if $t$ shift-test error on the scale in question exceeded the special toleran eren though the error was less than the basic tolerance on the sc under test.

This matter was considered by your Committee last year. Hower in the absence of adequate eridence as to the extent of this conditi and of the industry picture in relation thereto, this matter was l, for further study by the Committee. A report was to be made this Conference.

A comprehensive study has been made. More than 700 tests wf conducted by selected officials in various sections of the country, a by scale manufacturers. The results of these tests, which were $c$ ducted strictly in accord with code requirements, have led us to $t$ conclusion that the special shift-test tolerances for small-capaci scales, with stabilized load-receiving elements, are no longer reouirec

This matter has been discussed with the scale industry. Your Co? mittee understands that the present attitude of the industry is syml thetic to this recommendation. The scale industry is vitally concern orer the method to be emploved in making the shift test. With $t$ adoption of this amendment, weights and measures officials should doubly careful to make their tests in strict accordance with the $\mathrm{pr}$ visions of National Bureau of Standards Handbook 44, and as or lined in National Bureau of Standards Handbook 37. Yo Committee urges all officials to cooperate fully in this respect (s fig. 7 ).

Your Committee recommends that tolerance T.1.1.2. of the Sc: Code be amended to read as follows:

T.1.1.2. To Shift Tests.-Basic tolerances shall be applied.

\section{Recommendation 2}

In connection with Recommendation 2, your Committee would poi out that there are now separate codes for bulk plant meters (liqui measuring device code) and vehicle tank meters (vehicle tank code Furthermore, the same accuracy should be maintained in behalf receivers of products from these several types of meters. Tre shou aroid, insofar as possible, differentiations because of method or ty of derice used. All of these devices handle a common product, al the choice of devices lies with the rendor of the product. In fairne. to the receivers of the product, we feel that the present codes a a dequate.

Your Committee recommends that no action be taken on this re ommendation.

\section{Recommendation 3}

In regard to Recommendation 3, it was represented that the prese: tolerances are not being generally observed, and that tests of the 


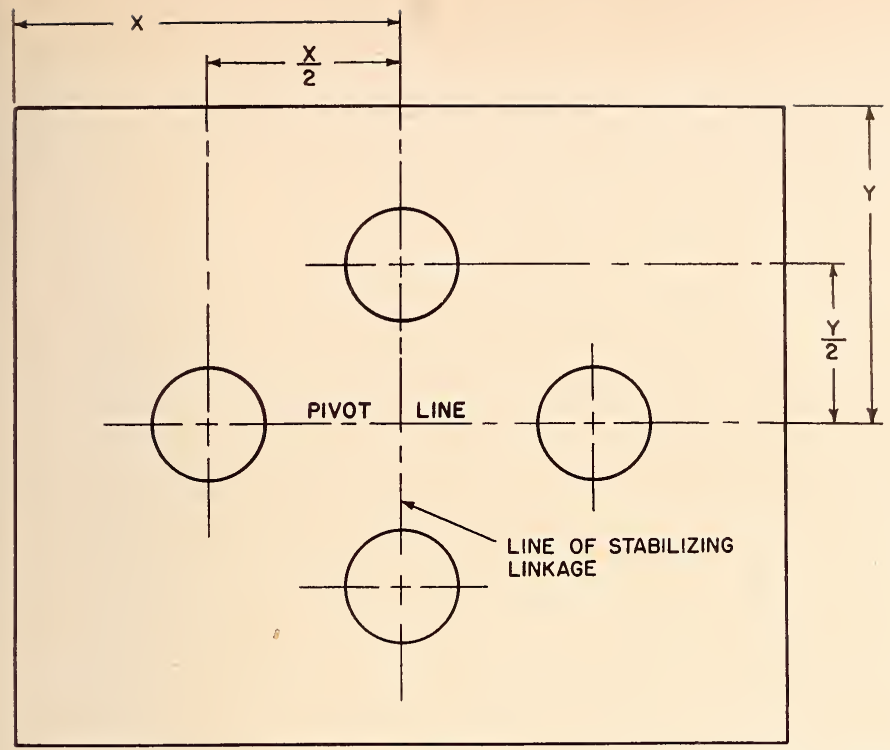

UTRE 7. Test-weight positions for shift test on small-capacity scales with stabilized load-receiving elements.

istance between center and edge of load-receiving element-parallel to pivot line ; distance between center and edge of load-receiving element-parallel to line of stalizing linkage; circles indicate positions of test load equal to one-half capacity of the ale.

ices are usually made with 5-gallon standards; that devices reachthe maximum tolerance of 7 cubic inches on 5 gallons would, on gressive error, be off more than the tolerances allowed on deliveries 10 gallons or more. It has also been pointed out that these rance values have not been amended since 1921 .

resently, this portion of the table particularly affects retail gasodispensing units. Correspondence has been had with the various nufacturers of these units, and they have indicated to your Comtee that their devices can meet the new proposed tolerances.

1 hearing was granted by your Committee to the interested parties relation to this proposed change, consisting of representatives of petroleum industry and representatives of the Gasoline Pump nufacturers Association. Objection was offered to this change both phases of industry on the ground that the present tolerance more severe than tolerances in relation to some other types of asuring devices. 'They further argued that attendant on this type measuring element are certain related mechanical devices which, and of themselves, present certain problems, and that at the mont they have some doubt as to whether further perfection can be ieved in these related elements to accomplish compliance with eduction in the tolerance. The further argument was advanced on part of the petroleum industry that this reduction would entail them considerable expense from the maintenance standpoint. The rgested change is not one of great degree, and there is some ques$n$ in the minds of your Committee as to the possibility of improvent in devices to meet the suggested change, as well as the added rden of maintenance of these devices. In some measure it may 
be true that in some juridictions adequate equipment may not present for desirable tests. Your Committee has deliberated to $g_{7}$ length and has carefully weighed all the arguments, and we $\mathrm{r}$ recommended that this matter be committed to further study dur the ensuing year, the study to be participated in by industry as $r$ as by weights and measures officials.

\section{Recommendation 4}

With reference to Recommendation 4, the Southern Association: recommended to the National Conference last year that Scale Regi tion R. 5. be amended by striking out the word "retail". At $t$ time it was the thought of your Committee that, in view of difficulties encountered in attaining compliance with Regulation $\mathrm{R}$ which was of recent adoption, this proposed amendment was too $\mathrm{F}$ cipitate. It was also the opinion of your Committee that the prim: purpose of the aforementioned regulation was consumer protecti No action, therefore, was recommended by your Committee last ye

It now appears that progress has been made in the production of ] priced, compensated spring scales for use in the retail field. A some progress has been made in the production of these scales suita for use in the wholesale field. A hearing was held on Sunday, w representatives of industry present, and, as a result of the heari your Committee recommends the following amendment:

Amend Regulation R. 5. of the scale code by deleting the word "retail in the second line thereof. This amendment to become effective Januar $1,1953$.

The effective date of the proposed change was deferred so that mal facturers and users would be allowed time in which to comply $\mathrm{w}$ this new requirement.

\section{CODE FOR LIQUID-MEASURING DEVICES}

It has been called to the attention of your Committee that there some confusion in the interpretation of the language in Specificati S. 2.6., which reads as follows:

S. 2.6. Air Elimination.-A meter device shall be equipped with an effer tive mechanical air eliminator or other effective means to prevent passag of air or vapor through the meter.

This situation has precipitated lack of uniformity in methods of $t$ and probable inadequacy of scope of test particularly involving $\mathrm{m}$ tiple dispensing units operating from a single source of power. I specification as now written is intended to cover in its requiremes each dispensing unit. This same requirement was expressed in NI Handbook 22, Specification 5, as follows:

In a pump discharge unit, a mechanical air eliminator or other mean: shall be installed adjacent to the meter inlet. [Italics ours.]

and in NBS Handbook 29, Specification 5, the last sentence thereof, follows:

* * * In a pump discharge unit, a mechanical air eliminator or othe means shall be provided in such a position that it will effectively preven the passage of air or vapor through the meter. 
mend S.2.6. on page 61 of the Code for Liquid Measuring Devices ake the last sentence thereof read as follows:

a pressure-type unit, a mechanical air eliminator or other effective means 1 be provided in such a position that it will effectively prevent the passage r or vapor through the meter.

has been brought to the attention of the Committee that there is e confusion in interpretation of N.1.2. Testing Drafts, both elation to some types of retail devices and wholesale devices. The sent wording at the end of the first sentence reads:

* * * for other types of retail devices used for dispensing motor fuel, sting drafts of at least 5 gallons shall be utilized.

-pparently this language has given rise to the thought that no test ess than 5 gallons should be made on a meter type device. This is the thought of the Committee. As you are doubtless aware, the prevalent type of retail device for dispensing motor fuels is the alled meter type. It is not necessary to regularly test this type ice at each indication throughout its designed delivery range. ting drafts of 5 gallons are suggested as convenient units. It is gested that testing drafts of at least this amount shall be employed liny series of tests on a meter type device. This is not intended to clude the testing of these devices at any other point, however.

Te recommend that paragraph N.1.2. be amended, for the purpose larification, to read as follows:

1.2. Testing DRAfts.-The full capacity delivery and each intermediate very for which the device is designed shall be tested in the case of retail on-type and visible-type devices; for other types of retail devices used for lensing motor fuel, testing drafts of one or more amounts, including drafts it least 5 gallons, shall be utilized. For wholesale devices, testing drafts fuld be equal to at least the amount delivered by the device in 1 minute at its imum discharge rate, and shall in no case be less than 50 gallons.

The report of the Committee on Specifications and Tolerances was discussed a by item, as it was presented by the Committee chairman. Each amendit was acted upon individually, and, at the conclusion of the report, the Comtee's recommendations were adopted as a whole.)

\section{REMARKS OF MR. ARTHUR SANDERS}

Mr. SANDers: I would like to call the attention of the Conference two things concerning the changes which have been made in the 4 scale code. The first relates to the shift test. I want to emphasize $t$ the Specifications and Tolerances Committee asked the National reau of Standards to prepare a chart showing the correct positionof weights in making the shift test on small-capacity scales with bilized load-receiving elements. We believe that the chart which Bureau prepared should be widely distributed and publicized ong all weights and measures inspectors. We hope to do this ong all the sales and service people in the scale industry, so that ryone can be operating according to the same correct procedure. 'at was really the only objection that the scale industry had to this ange in the scale code, which eliminates this special tolerance e fig. 7).

The other matter that I would like to call to your attention is the ohibition against the use in wholesale sales of foodstuff, except rits and vegetables, of uncompensated spring scales. We have made extensive survey and have had many discussions with the Specifica- 
tions and Tolerances Committee. I think it should be brought to attention of weights and measures departments all over the coun that there are some very good manufacturers of spring scales, hanging type, who do not have an uncompensated spring scale. think all have worked toward the development of such scales, $\mathrm{p}$ ticularly the small-capacity scales. It is not such an easy mat You do not just put a compensating spring in the old uncompensa spring scale housing and develop a satisfactory compensated spr scale. I think it should be called to your attention that this progr is not going to be easy, and that some of the manufacturers may be able to develop satisfactory scales by the first of January 1953.

Some of our association members do have these scales. Some them do not. The association took a neutral position on this mat In fairness to those manufacturers who have not been able to deve these scales, I want to call this situation to your attention.

\section{REPORT OF THE NATIONAL CONFERENGE COMMITTEE ON RESOLUTIONS, PRESENTED BY MILES A. NELSON, CHAIRMAN}

\section{CONGRATULATIONS TO DR. A. V. ASTIN}

Whereas, Dr. A. V. Astin has been appointed Director of the National Bur of Standards by the President of the United States; and

Whereas, the said Dr. Astin favored the 37th National Conference on Weig and Measures with a very interesting and educational talk on the activities the National Bureau of Standards ; and

Whereas, Ir. Astin has always demonstrated a keen appreciation of problems facing weights and measures officials and has evidenced a sinc desire to aid weights and measures officials in the derelopment of uniform I cedures and solving tricky problems; Therefore, be it

Resolved, That the 37th National Conference on Weights and Measures $c$ gratulate Dr. A. V. Astin on his appointment and extend to him our best wis for a progressive administration.

\section{APPREGIATION TO DIRECTOR AND STAFF OF THE NATIONAL BUREAU OF STANDAI}

Whereas, Dr. A. V. Astin, Director; W. S. Bussey, Chief of the Office of Weig and Measures; and their rery able and efficient staff have extended ralua assistance and guidance to the 37th Conference, for which the Conference very grateful; Therefore, be it

Resolved, That this, the 37th National Conference on Weights and Measul does appreciate such cooperation and assistance from the National Bureau Standards and wishes to make this resolution a part of the records of $t$ Conference.

\section{APPRECIATION TO COOPERATING OFFICIALS}

Whereas, the gorerning officials of the rarious States, counties, and mur ipalities, through their manifest interest in weights and measures work, he made it possible for their respective jurisdictions to be represented at this 3 ' National Conference on Weights and Measures; Therefore, be it

Resolved, That this, the 37th National Conference on Weights and Measur does appreciate such cooperation and assistance and wishes to make this reso tion a part of the records of this Conference.

\section{APPRECIATION TO MANAGEMENT OF HEADQUARTERS HOTEL}

Whereas, the management of the Wardman Park Hotel has done everythj within its power to make our Conference a success; Therefore, be it

Resolved, That this, the 37th National Conference on Weights and Measu: does express its warmest appreciation and thanks to the management of $s i$ hotel for their cordial hospitality and cooperation during our meetings; be further

Resolved, That the Secretary of this Conference transmit a copy of $\mathrm{t}$ ] resolution to the management of the Wardman Park Hotel. 
hereas, The Honorable F. Joseph Donohue added much to the success and rment of our meeting by delivering a most cordial welcome to the City of hington; Therefore, be it

esolved, That this, the 37th National Conference on Weights and Measures hereby acknowledge its appreciation for the courtesies extended by Mr. ohue.

\section{APPREGIATION TO THOSE PARTICIPATING IN PROGRAM}

Thereas, various committees, speakers, and individuals have given generously their valuable time and efforts to make the 37th National Conference on ghts and Measures a success ; Therefore, be it

esolved, That the 37th National Conference on Weights and Measures does aby record its grateful appreciation to all who have contributed to the success the Conference.

\section{APPRECIATION TO THE PRESS, RADIO, AND THE SCALE JOURNAL}

Thereas, the press and radio of the City of Washington have been generous eporting the activities of our present meeting ; and

thereas, the Scale Journal has likewise been generous in publishing news and ance notices of our present meeting; Therefore, be it

Cesolved, That this, the 37th National Conference on Weights and Measures, $s$ hereby record its appreciation to the press and radio of the City of shington and to the Scale Journal.

\section{ON INVESTIGATION FOR ACCURATE DETERMINATION OF AXLE LOADS ON HIGHWAY VEHICLES}

Nhereas, weights and measures officials throughout the nation are continually uested to test axle load scales and loadometers and to recommend weighing sedures in order to obtain accurate determinations of axle loads of highway icles; and,

Vhereas, there is no record of a comprehensive and scientific investigation $r$ having been made into a method for an accurate determination of axle loads highway rehicles; and

Vhereas, the extent and causes of wide variations in results of such tests of loads are unknown; Therefore, be it

lesolved, That this 37th National Conference on Weights and Measures recomad and request that the National Bureau of Standards, in cooperation with States, the U. S. Bureau of Public Roads, and the trucking industry, institute extensive and scientific investigation into the entire field of testing axle loads levise a method for accurately obtaining a determination of such loads.

(Signed) Miles A. Nelson, Chairman, A. C. BECKER,

WALTER L. DANiels, JOHN E. MAHONEY,

M. G. RICE,

Louis SNow,

Committee on Resolutions.

The report of the Resolutions Committee was adopted by the Conference.)

\section{REPORT OF THE NATIONAL CONFERENCE TREASURER, GEORGE F. AUSTIN, JR.}

May 1, 1952

ance on hand May 1, 1951

EIPTS :

lay 25-Registration fees-1951 Conference 273 at

\begin{tabular}{|c|c|c|c|}
\hline Interest & accrued & 14.35 & \\
\hline
\end{tabular}


Мay 22-25, 1951-

Expenses of $36 \mathrm{th}$ National Conference

National Bureau of Standards testimonial scroll_._-

$\$ 946.30$

Rubber stamp (Registration Fee)

45. 00

Two receipt books at $\$ 3.30$ ea

Twelve copies "Parliamentary Law" booklets

1. 44

6. 60

2. 45

Total expenses

Balance on hand May 1, 1952

Respectfully submitted,

1,01

(Signed) Geonge F. Austin, Treasure

('The Treasurer's report was adopted by the Conference.)

(Upon motion of L. E. Witt, the Conference voted to authorize the Secret to draw upon the Treasury to pay the customary and usual expenses of Conference.)

\section{RALPH W. SMITH MADE HONORARY LIFE MEMBER}

Mr. Wiтt : Gentlemen, attending with us at this year's Conferenc an outstanding weights and measures personality. He is wearing w inordinate pride the Conference badge of identification. It shor be the other way around. We are signally homored by his prese] upon this occasion. He has served the National Bureau of Standa: for more than thirty years. He has done much for the National $\mathrm{C}_{1}$ ference. He has guided us. He has written many practical hal books, which are in fact our official manuals in the conduct of ( business. I, therefore, move that this gentleman, Ralph W. Smith, accorded the recognition which he has so rightfully earned, and $t]$ this 37th National Conference on Weights and Measures bestow uf him an honorary life membership; and that the Secretary of 1 Conference be authorized to address a communication to Mr. Sm apprising him of the action of the Conference.

(The motion was adopted unanimously.)

(R. W. Searles, Chaplain, closed the meeting with prayer, and the This seventh National Conference on Weights and Measures adjourned at 11: a. m.)

\section{MEETING OF THE EXEGUTIVE COMMITTEE}

SECRETARY's NotE.-Immediately following adjournment of the Conferer a meeting was held of the newly elected Executive Committee of the Conferer This meeting was attended by 15 of the 24 members. Dr. A. V. Astin, Preside presided. The following decisions were made with respect to the Thirty-eig] National Conference on Weights and Measures:

The Conference will extend over 4 days, with two sessions on the first day, session on the second day, two sessions on the third day, and one session on fourth day.

The dates for the Conference will be May 19, 20, 21, and 22, 1953.

The headquarters for the Conference will be Wardman Park Hotel, Washingt D. C.

The morning session on the second day of the Conference will be held at National Bureau of Standards if suitable arrangements can be made. Ot] sessions of the Conference will be held at the headquarters hotel.

The customary informal Conference party will be held on the evening of second day of the Conference.

Some form of special entertainment will be provided for the ladies attend: the Conference. 
S. Bussey, Conference Secretary, was instructed to arrange the program for Chirty-eighth National Conference.

Secretary was requested to arrange for an informal open house and tour e National Bureau of Standards laboratories on the afternoon of the second of the Conference.

addition to the abore decisions in regard to the Thirty-eighth National erence on Weights and Measures, the Executive Committee recommended the practice of furnishing to the delegates various interesting publicity ses by the National Bureau of Standards be continued and expanded.

le Committee also instructed the Secretary to furnish an appropriate HonorLife Membership card or certificate to Ralph W. Smith.

\section{PERSONS ATTENDING THE CONFERENCE}

\section{DELEGATES-STATE, CITY, AND COUNTY OFFICIALS CALIFORNIA}

James E. Brenton, Chief, Bureau of Weights and Measures, Department of Agriculture, Mull Building, Sacramento.

aty:

Alameda

Los Angeles

San Diego.

Bridgeport

nty :

Fairfield

Hartford-

Tolland

Windham
Williay A. KerLin, Sealer of Weights and Measures, 333 Fifth Street, Oakland 7.

Charles Morris Fuller, Sealer of Weights and Measures, 3200 North Main Street, Los Angeles 31.

H. J. MCDAdE, County Sealer of Weights and Measures, 1480 "F" Street, San Diego.

\section{CONNECTICUT}

Frank M. Greene, Deputy Commissioner, Food and Drug Commission, State Office Building. Hartford.

Frank J. Delaney, State Inspector of Weights and Measures, State Office Building, Hartford.

Clarexce F. Roberts, State Inspector of Weights and Measures, State Office Building, Hartford.

LouIs Sxow, Sealer of Weights and Measures, 925 Main Street.

William E. SHeeHy, Sealer of Weights and Measures, County Court House, Bridgeport.

Aluin B. Coger, Deputy Sealer of Weights and Measures, Newtown.

ERNEST R. WILson, Deputy Sealer of Weights and Measures, P. O. Box 269, Norwalk.

Fred E. McKinney, Sealer of Weights and Measures, Hartford County Building, 95 Washington Street, Hartford.

JosePH J. FANELLI, Deputy Sealer of Weights and Measures, Hartford County Building, 95 Washington Street, Hartford.

Willian F. Masinda, Sealer of Weights and Measures, West Willington.

Johх T. Bexpett, County Sealer of Weights and Measures, Box 76, Canterbury.

\section{DELAWARE}

Martin L. Kinney, Regulator of Weights and Measures, 600 Delaware Street, New Castle. 


\section{DISTRICT OF COLUMBIA}

Department of Weights, Measures, and Markets, 300 Indiana Arenue, $>$ Washington

District

State-

City :

Jacksonrille

Miami

State

City : Chicago

State

City :

Fort Wayne

Gary

Terre Haute

County :

Grant.

Vigo
J. Thomas Kexnedy, Director.

James G. Daxce, Deputy Director.

JoHn M. Boccher, Supervisor.

G. Stuart Reeder, Supervisor.

WALTER W. BRANDT, Inspector and Investig Leo F. Brooks, Inspector and Investigator.

William T. Bruxsox, Inspector and Inrestig

Walter R. Cornelius, Inspector and In gator.

Leo A. GNotta, Inspector and Inrestigator.

Fenton C. Harbour, Inspector and Inrestig

William H. Jexisings, Inspector and Ini gator.

Theodone B. Midnleton, Inspector and Int gator.

RaLPH A. Moxtgonery, Inspector and Int gator.

Bernard A. Pettit, Inspector and Inrestig:

Francis M. WARTER, Inspector and Inv gator.

Wooprow W. Wects, Inspector and Inrestig:

\section{FLORIDA}

NALLs BerRyMan, Supervisor, Weights Measures Division, Department of Agriculi Nathan Mayo Building, Tallahassee.

Howard E. Crawford, Inspector of Weights Measures, 431 West Eighth Street.

Harvey E. Howard, Supervisor of Weights Measures, Department of Public Welfare.

\section{GEORGIA}

John W. D. Harvey, Assistant Chemist, s Oil Laboratory, 524 State Office Build Atlanta.

\section{ILLINOIS}

John J. Levitt, Superintendent of Standa 615 Armory Building, Springfield.

Wildiam R. Отто, State Inspector of Wei and Measures, 505 South Clinton St Bloomington.

IRvine M. LeVT, Sealer of Weights and II ures, Room 608 City Hall.

Frank J. Fitzgerald, Chief Deputy Inspecto Weights and Measures, Room 608 City Ha

\section{INDIANA}

RolisN E. MeEK, Director, Division of Wei: and Measures, Board of Health, $1330 T$ Michigan Street, Indianapolis.

James A. Hilgemans, Deputy State Inspecto Weights and Measures, 301 South Clin Street.

Cleo C. Morgax, City Sealer of Weights Measures, City Hall, Room 204.

JoHN T. HARPER, Inspector of Weights and M ures, 205 City Building.

Reuben C. Parks, Inspector of Weights Measures, Court House, Marion.

William H. RoberTs, Inspector of Weights Measures, Room 5, Court House, Terre Ha 
JAMES W. ReEse, Supervisor, Division of Weights and Measures, Department of Agriculture, Des Moines.

\section{KANSAS}

J. Fred True, State Sealer, Weights and Measures Division, Board of Agriculture, 915 Harrison Street, Topeka.

LEw Gilloway, Chairman, Weights and Measures Committee, Board of Agriculture, 915 Harrison Street, Topeka.

\section{KENTUCKY}

Ben S. Adars, Commissioner of Agriculture, Frankfort.

GEorge L. JoHnsox, Director, Dirision of Weights and Measures, Department of Agriculture, New State Capitol, Frankfort.

\section{Louisville}

William H. Isixg, JR., Superintendent, Dirision of Weights and Measures, Department of Public Safety, Room 3, City Hall.

\section{LOUISIANA}

Alois J. MAYer, Director, Division of Weights and Measures, Department of Agriculture and Immigration, P. O. Box 951, Baton Rouge 1.

\section{MAINE}

JAMes A. Boyle, Deputy State Sealer, Bureau of Weights and Measures, Department of Agriculture, State House, Augusta.

Charles James Wills, Sealer of Weights and Measures, 389 Congress Street.

\section{MARYLAND}

JoHN E. MAHoxey, Superintendent of Weights and Measures, State Department of Markets, Board of Agriculture, Cniversity of Maryland, College Park.

Dr. Paul E. Nystrom, State Department of Markets, University of Maryland, College Park.

ty : Baltimore

George H. Leithauser, Senior Assistant Superintendent of Weights and Measules, 1106 Municipal Building.

MorRIs BRATMAN, Inspector of Weights and Measures, 1106 Municipal Building.

EDwix EDwARD JAFFA, Inspector of Weights and Measures, 1106 Municipal Building.

unty :

Baltimore

Fraxk J. Viтtek, Chief Inspector of Weights and Measures, Offutt Building. Towson 4.

GEorge A. KLEIN, Assistant Inspector of Weights and Measures, Offutt Building, Towson 4.

Montgomery
A. Morton Thomas, Director, Department of Inspection and Licenses, Court House, Rockville.

WILFORD EluIs DAYHoFf, Inspector of Weights and Measures, County Court House, Rockville.

\section{MASSACHUSETTS}

Jону P. McBride, Director of Standards and Necessaries of Life, 194 State House, Boston. 
City :

Cambridge

Fall River

Malden

Medford

West Springfield

County: Arlington

State

City :

Dearborn

Detroit

Highland Park

Lansing

Pontiac

City : Minneapolis

State

$-$

ures, Municipal Building.

SEPH M. O'NeIL, Sealer of Weights and M $€$

Janes A. Benson, Sealer of Weights and Me ures, City Hall Annex.

JoHN .J. KELLEX, City Sealer of Weights Measures.

Willia S. Vince, Deputy Sealer of Weights : Measures, City Hall.

Carl A. Jacobson, Sealer, Department of Weig and Measures.

Janes J. Dolan, Sealer, Weights and Measu Department, Arlington Town Hall, Arlingt

\section{MICHIGAN}

Miles A. Nelson, Chief, Bureau of Market and Enforcement, Department of Agricultu 725 State Office Building, Lansing 13.

Martin C. Griffith, Councilman, City Coun Mitchell O. Nickon, City Sealer of Weights a Measures, 4731 Korte Street.

Charles H. Waller, Inspector, Department Licenses, Weights, and Measures, Police a Courts Building.

George F. Austin, Jr., Deputy Sealer of Weig] and Measures, 740 Elmwood Arenue.

William B. Heaslip, Supervising Inspector, I reau of Markets, Weights, and Measures, 7 Elmwood Avenue.

JAMES F. BAKER, City Sealer of Weights a Measures, 25 Gerald Street.

Walter M. Saxton, City Sealer and Mark master, 333 North Cedar.

WALTER A. BAERWolf, Sealer of Weights a Measures, 8 North Perry Street.

\section{MINNESOTA}

Ering Hansen, Supervisor, Department Weights and Measures, Railroad and Wal house Commission, Corn Exchange Buildiı Minneapolis 15.

David LundeEn, State Weighmaster, Track a Hopper Scale Department, 320 Flour Exchan Building, Minneapolis 15.

Chris'tian Christensen, Inspector, Weights a Measures Department, 216 Corn Exchan Building, Minneapolis 15.

MELVin C. Ilstrup, State Inspector of Weigh and Measures, 2124 Riverside Avent Minneapolis.

Edvard J. Egan, Alderman-Chairman Weigh and Measures, Court House.

Russell S. AcKerman, Superintendent, Depal ment of Licenses, Weights, and Measurt Room 3, City Hall.

\section{MISSOURI}

City : University City

D. J. Almon, General Inspector, City Hall.

\section{NEVADA}

State

A. J. RAFAeL, Resident Inspector, Departme of Weights and Measures, Public Servi Division, University of Nevada, P. (). Bc 747 , Las Vegas. 


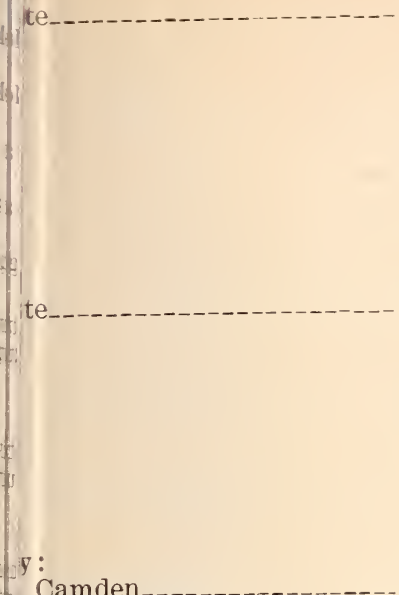

y:

\section{Clifton}

Englewood

Hoboken

Jersey City

Passaic

Paterson

Union City

inty :

Bergen

Camden

Cumberland

Mercer

Middlesex

Monmouth

Morris
C. A. Lyox, Director of Markets and Standards, Department of Agriculture, Concord.

ALFRED H. DITTRICH, Chief Inspector, Bureau of Weights and Measures, Department of Agriculture, Concord.

MAURICE. W. MULLex, Inspector of Weights and Neasures, Department of Agriculture, Concord.

\section{NEW JERSEY}

JoSePh G. Rogers, State Superintendent, Division of Weights and Measures, 187 West Hanover Street, Trenton 7.

Archie T. Suith, Assistant State Superintendent, Division of Weights and Measures, 187 West Hanover Street, Trenton 7.

Samuel H. Christie, Jr., Senior Inspector, Division of Weights and Measures, 187 West Hanover Street, Trenton 7.

Alfred DiPiero, Superintendent of Weights anà Measures, City Hall.

FELIX J. SANDRI, Superintendent of Weights and Measures, City Hall.

LEONARD DERIENzo, Superintendent of Weights and Neasures, City Hall.

Charles I. Romano, Superintendent of Weights and Measures, City Hall.

JoHN S. BURKe, Municipal Superintendent of Weights and Measures, City Hall.

PAUL DeVries, Superintendent of Weights and Measures, P. O. Box 663, Municipal Building.

JoSEPH SHAW, Assistant Superintendent of Weights and Measures, Municipal Building.

JosEPH P. LEONARD, Superintendent of Weights and Measures, 115 Van Houten Street.

Wrulay J. Kenoe, Assistant Superintendent of Weights and Measures, 115 Van Houten Street.

Alfred O. Oslund, Superintendent, Department of Weights and Measures, 3715 Palisade Arenue.

Michael J. Santimauro, Superintendent of Weights and Measures, 66 Zabriskie Street, Hackensack.

Ervest E. DAwson, Assistant Superintendent of Weights and Measures, 66 Zabriskie Street, Hackensack.

Albert C. Becker, County Superintendent of Weights and Measures, City Hall, Camden.

ALFRED LIRIo, Superintendent of Weights and Measures, Court House, Bridgeton.

Winfield K. Thompson, Assistant Superintendent of Weights and Measures, Court House, Bridgeton.

Palph M. Bodenweiser, Superintendent of Weights and Measures, Court House, Trenton.

Charles F. Sullivax, Superintendent of Weights and Measures, Room 208 Sheriff's Office Builāing, New Brunswick.

Glexy L. Berry, County Superintendent of Weights and Measures, 706 Eighth Arenue, Asbury Park.

Del G. Nelson, Superintendent of Weights and Measures, Court House, Morristown. 
County-Continued

Passaic

Union. and Measures, Administration Building, Pat son.

Williay Miller, Superintendent of Weig

JAMEs M. DIETz, Superintendent of Weights Measures, Court House, Elizabeth 4 .

\section{NEW YORK}

State

City

Binghamton

Buffalo

Jamestomn__._.

Lackawanna

Rochester.

Counts :

Erie

Monroe

Nassau

Niagara

\section{State}

State

state

City :

Akron__._._._._.

Cincinnati.
Dr. ErWix T. Moore, Assistant Commissior Department of Agriculture and Marke State Office Building, Albany.

Clemext A. Ba ker, Director. Bureau of Weig and Measures, Department of Agriculture a Markets, State Office Building, Albany.

JoHx J. LEoxARD, Supervising Inspector, $N$

МАттнеш G. RICE. Inspector, Bureau of Weig: and Measures, Department of Agriculture a Markets, S Marlette Place. Thite Plains.

Harri A. Lason, Sealer of Weights and Me ures, 60 Robinson Street.

Louis J. Schuster, City Sealer of Weights a Measures, Room 5̄, City Hall.

CARL A. LARsoN, City Sealer of Weights a Measures, 1 Fenton Place.

Johx J. SEres, City Sealel of Weights a Measures, 4 Rosary Arenue.

A NтHолт C. SAMENFink, City Sealer of Weig] and Measures, Department of Commer Rochester Food Terminal.

O. F. GAylord, County Sealer of Weights a Measures, County Hall, Buffalo.

EARL D. Hubble, Sealer of Weights and Me: ures. Room B, 1400 South Arenue, Rochest

Robert Tilliars, Sealer of Weights and Me ures. Old County Court House Annex, Mineo

WILlia KIRK, Jr., Assistant Sealer of IVeig] and Measures, Old County Court House. nex, Mineola.

Hexry C. Hilshoff. Sealer of Weights al Measures. 17 High Street, Lockport.

\section{NORTH CAROLINA}

C. D. BAtcox, Superintendent, Weights a Measures Dirision, Department of Agricultu 415 Agriculture Building, Raleigh.

JoHx I. Moore, Superrisor, Weights and Me: ures Division, Department of Agricultu 31S Morrison Irenue, Raleigh.

\section{NORTH DAKOTA}

J. C. GolL, Chief Inspector, Weights and Me: ures Department, Public Service Commissic Bismarck.

\section{OHIO}

T. D. Campbell. Deputy State Sealer, Divisi of Foods and Dairies, Department of Agric ture, 710 State Office Building, Columbus 15.

Robert K. Silotgh, City Sealer, Dirision Weights and Measures, 102 Municipal Buildir Wr. E. G. Rheis, Superintendent, Dirision Markets, Weights and Measures, Departine of Safety, 2nd Floor, Market House. York State Bureau of WVeights and Measu 24 Griswold Arenue. Tros. 
Continued

Lorain

tr: Medina

Erie

nty: Erie

Cranston

Providence

Gabor Toтн, City Sealer of Weights and Measures, 3019 Caroline Arenue.

Robert W. Searles, Deputy Sealer of Weights and Measures, Court House, Medina.

\section{PENNSYLVANIA}

Joseph F. Blickley, Director, Bureau of Standard Weights and Measures, Department of Internal Affairs, Capitol Building, Harrisburg.

Spexcer H. SeIghmax, Assistant Director, Bureau of Standard Weights and Measures, Department of Internal Affairs, Capitol Building, Harrisburg.

Patl F. Watson, City Inspector of Weights and Measures, City Hall.

Robert W. DAGgett, County Inspector of Weights and Measures, North Girard.

\section{RHODE ISLAND}

EDWARD R. Fisher, State Sealer of Weights and Measures, Department of Labor, State House, Providence.

James F. Corrigax, Deputy State Sealer of Weights and Measures, Department of Labor, Providence.

Ariraxp E. RExzi, Sealer of Weights and Measures, 14 Tulip Circle, Garden City, Cranston.

EDWard F. Moras, Superintendent of Weights and Measures, 141 Fountain Street.

\section{SOUTH CAROLINA}

J. Ror Joxes, Commissioner, Department of Agriculture, P. O. Box 1080, Columbia.

Carl H. Stender, Assistant to Commissioner, Department of Agriculture, P. O. Box 1080, Columbia.

Alex H. Gibert, Director, Bureau of Inspection. Department of Agriculture, P. O. Box 1080, Columbia.

W. J. Sexr, Inspector of Weights and Measures, Department of Agriculture, Box 1080, Columbia.

\section{SOUTH DAKOTA}

Fred Lindekugel, Public Utilities Commissioner, Heary Scales Department, Pierre.

\section{TENNESSEE}

Nashville

Toy Webb, Sealer of Weights and Measures, 300 Demonbreun Street.

Oak Ridge-

Loxgstreet Cavetr, Inspector, Management Services, Inc., 313 E. Forest Road.

\section{TEXAS}

Fraxcis L. Goone, Chief, Division of Weights and Neasures, Department of Agriculture, Austin 14.

Bervie A. Moore, Field Supervisor, Dirision of IVeights and Measures, Department of Agriculture, Austin 14.

Houston

Pete J. Vitopil, Weights and Measures Inspector, City Hall.

San Antonio

Thomas H. Coghill, City Engineer, Department of Public Works. 
City : Salt Lake City

City :

Norfolk

Petersburg

Richmond

County : Arlington

State

City: Seattle

State

City :

Kenosha

Milwaukee

Racine

Sheboygan

Superior.

Wausau lidvin C. Westwood, City Sealer of Weights Measures, 118 East First Street.

\section{VIRGINIA}

R. D. Thompson, Supervisor, Weights and $\mathbf{M}_{6}$ ures Section, Division of Markets, Departm of Agriculture and Immigration, $1200 \mathrm{E}$ Main Street, Richmond.

E. Brooks Green, Inspector of Weights Measures, Chatham.

JosepH EDWARD MICHAUx, Inspector of Weig and Measures, RFD \#3, Richmond.

Webster K. Tripple, Chief, Bureau of Weig and Measures, City Market Building.

James A. Parron, Assistant Sealer of Weig and Measures, City Market Building.

C. R. THompson, City Sealer of Weights : Measures, City Hall.

Claude Roane Branch, Assistant Inspector Weights and Measures, City Hall.

Conway C. Mundr, Chief, Bureau of Weig and Measures, Room 121, Mosque Buildi Laurel and Main Streets.

Alvin L. BrockWELL, Inspector of Weights Measures, The Mosque Building, Laurel Main Streets.

M. L. RICE, Inspector of Weights and Measu The Mosque Building, Laurel and M Streets.

Joseph W. Higgins, Assistant Sealer of Weig and Measures, Arlington County Court Hol Arlington.

\section{WASHINGTON}

T. A. Carter, Supervisor, Division of Weig and Measures, Department of Agriculture, Old Capitol Building, Olympia.

Walter L. Daniels, Director, Division of censes and Standards, Room 100, County-C Building.

Donald M. Turnbule, Supervisor, Division Licenses and Standards, Office of the $\mathrm{Col}$ troller, 100 County-City Building.

\section{WISCONSIN}

William Watermax, Supervisol, Weights : Measures Inspection, 419 S. W'. State Capi Madison.

Felix MAyer, Sealer of Weights and Measui City Hall.

Louis E. Witt, Sealer of Weights and Measu. 1331 North Fifth Street.

Robert J. Zierten, Sealer of Weights and Mt ures, City Hall.

J. A. Peinert, Sealer of Weights and Measur Oscar E. Roeseler, City Sealer of Weights : Measures, City Hall.

A. K. Michaelson, City Sealer, Department Weights and Measures, Market Square Bu ing.

\section{WYOMING}

Elvin Leemax, Superintendent, Division Weights and Measures, Department of Agri ture, 310 Capitol Building, Cheyenne. 


\section{DELEGATES-NATIONAL BUREAU OF STANDARDS}

ector"s Office:

A. V. Astin, Director.

A. T. McPherson, Associate Director.

L. J. Briggs, Director Emeritus.

William S. Bussey, Chief, Office of Weights and Measures.

Malcolm W. Jensen, Assistant Chief, Office of Weights and Measures.

H. HAIg Russeld, Chief, Scale Section, Office of Weights and Measures.

CHARLES H. OAKLEY, Coordinator, Office of Weights and Measures.

Herbert L. Badger, Physicist, Office of Weights and Measures.

Mrs. K. M. Schwarz, Attorney-Editor, Office of Weights and Measures.

Mrs. F. C. BeLL, Chief Clerk, Office of Weights and Measures.

JoHn FrIedman, Office of Scientific Publications.

Bernard H. Barbour, Office of Scientific Publications.

mistry Division :

John H. Eiseman, Chemist, Gas Chemistry Section.

hanics Division :

B. C. KeYsAR, Capacity, Density and Fluid Meters Section.

JoHn C. Hughes, Project Leader, Capacity, Density and Fluid Meters Section.

Grace C. Mulligan, Physicist, Capacity, Density and Fluid Meters Section.

Douglas R. Tate, Physicist, Engineering Mechanics Section.

L. B. Maccrdx, Chief, Mass Section.

T. W. Lashof, Assistant Chief, Mass Section.

ics and Metrology Division:

L. V. Judson, Chief, Length Section.

RAlPH W. Crouch, Jr., Photometry and Calorimetry Section.

sultants :

E. C. Crittenden.

WILMER SOUdER.

\section{GUESTS REPRESENTING UNITED STATES GOVERNMENT}

s. Department of Agriculture:

A. E. Browne, Research and Statistics Division, Fruit and Vegetable Branch, Production and Marketing Administration, Washington 25, D. C.

L. C. Carey, Fruit and Vegetable Branch, Production and Marketing Administration, Washington $25, \mathrm{D}$. C.

EDWARD A. MURPHy, Division of Animal Industry, Washington 25, D. C.

Charles L. Richard, Supervisor of Scales and Weighing, Livestock Branch, 3530 South Building, Washington 25, D. C.

R. L. Spangler, Standardization Section, Fresh Products Standardization and Inspection Division, Fruit and Vegetable Branch, Production and Marketing Administration, Washington 25, D. C.

D. R. Stokes, Research and Statistics Division, Fruit and Vegetable Branch, Production and Marketing Administration, Washington 25, D. C.

S. Department of Commerce :

Oliver H. WATson, Section Chief, Scales and Balances Section, National Production Authority, 2147 Temporary T Building, Washington 25, D. C.

W. E. Braithwaite, Chief, Packaging Section, Commodity Standards Division, Washington $25, \mathrm{D}$. C.

. Food and Drug Administration:

Robert A. Osborn, Chemist, Food Division, Washington 25, D. C.

Sumner C. Rowe, Chemist, Food Division, Washington 25, D. C.

3. Treasury Department:

Norman T. MoRseld, Tobacco Branch, Alcohol and Tobacco Tax Division, Bureau of Internal Revenue, Washington 25, D. C.

\section{GUESTS REPRESENTING MANUFACTURERS OF WEIGHING AND MEASURING DEVICES}

Weather Springs: J. W. Rockefeller, Jr., Engineer, 140 Cedar Street, Tew York $6, \mathrm{~N}$. Y.

erican Meter Co.: W. V. Stockton, Jr., P. O. Box D, Wynnewood, Pa.

omer Brothers Co.: Raynor M. Holmes, Research Engineer, Newark, N., Y. g-Erickson Corporation: L. H. Erickson, President, 469 East Ohio Street, thicago 11, Ill.

wser, Inc. : W Watter M. Harks, Vice President, Fort Wayne, Ind. 
Brodie, Ralph N., Co., Ine.

C. J. McCaffreY, Vice President, Eastern Division Headquarters, 550 So

Columbus A venue, Mount Vernon, N. Y.

D. S. Jornson, Vice President in Charge of Sales, Oakland, Calif.

Don W. Kingsier, 550 South Columbus Arenue, Mount Vernon, N. Y.

Chatillon, John, \& Sons :

J. G. Hugel, Sr., Sales Representative, 85 Cliff Street, New York 38, N.

George C. Reiley, Vice President-Sales, 85 Cliff Street, New York 38, N

Container Corporation of America: William W. Deissler, Jr., Sales Reseal Manayunk, Philadelphia 27, Pa.

Continental Can Co., Inc. : Warrex D. Ayres, Assistant Product Sales Mana 349 Oraton Street, Newark, N. J.

Creamery Package Mfg. Co. : L. T'. Gustafson, 1243 West Washington Boulera Chicago 7 , Ill.

Dairy Equipment Co. : K. S. Hart, Madison, Wis.

Dayton Pump \& Mfo. Co. :

James F. Pease, Field Sales Manager, 500 Webster Street, Dayton, Ohio

Roвевт H. SсnосNivg, Assistant Chief Engineer, 500 Webster Street, Dayt Ohio.

Detecto Scales, Inc. :

D. S. Hammeniran, Executive Vice President, 540 Park Arenue, Brook 5, N. Y.

Mack Rapp, Vice President, 540 Park Arenue, Brooklyn 5, N. Y.

Mrs. Carrie G. Woodland, Representative, Woodland's Temple Gro Fellsmere, Fla.

Erie Meter Systems, Inc. :

Paul R. Fishburn, Chief Engineer, Erie 6, Pa.

Randall L. Holdridge, Manager, Air Port Fueling Division, P. O. Box 5 Erie, Pa.

William B. Johnson, Jr., Manager of Sales, P. O. Box 559, Erie, Pa.

Exact Weight Scale Co. :

JoHn Beeson, 944 West Fifth Avenue, Columbus 8, Ohio.

K. B. NefF, President, 944 West Fifth Avenue, Columbus 8, Ohio.

W. A. Schieurer, Vice President, 944 West Fifth Avenue, Columbus 8, Oh

James F. Sullivan, Chief Engineer, 944 West Fifth Avenue, Columbus Ohio.

M. D. Varney, 944 West Fifth Arenue, Columbus 8, Ohio.

Ex-Cell-O Corporation, Gene R. Andre, Pure Pak Division, 1200 Oakman Bou vard, Detroit, Mich.

Fairoanks, Morse \& Co. :

Arthur A. Hafrer, Chief Engineer, St. Johnsbury, Vt.

C. A. Hennie, Field Engineer, 657 East 25th Street, Baltimore 18, Md.

Cras. W. King, Manager Scale Department, 760 Lee Street, S. W., Atlanta, Ga.

Leonard J. McGuire, Manager, St. Johnsbury, Vt.

G. C. Wonthley, Manager Seale Division, 600 South Michigan Aven Chicago, Ill.

Forschner, R. H., Co.: Richard A. Forschner, 205 Third Avenue, New Yo $3, \mathrm{~N}$. Y.

Fuller, H. J., C. O.: H. J. Fuller, President, 1371 West Third Arenue, Columb

12, Ohio.

Gilbert \& Barker Manufacturing Co. :

Clifford A. Bellows, West Springfield, Mass.

William Keay, West Springfield, Mass.

Josepir A. Logan, Manager, Patents and Weights and Measures, We Springfield, Mass.

Girton Mfg. Co. : Thomas F. Douglas, Millville, Pa.

Gould Equipment Co. : Earlon W. Barrett, Representative, Portland, Me.

Granberg Corporation: Fred H. Fiflding, Washington Representative, 1507

Street N. W., Washington, D. C.

Gurley, W. \& L. F.: Franklin G. Willians, Washington Representative, 55]

Nevada Avenue N. W., Washington 15, D. C. 
ey, H. A., Associates, Inc. :

H. A. Hadlex, President, 25 Pearl Street, Burlington, It'.

Toseph S. Peterson, General Sales Manager, 25 Pearl Street, Burlington, Vt. rt Manufacturing Co. :

MURray W. CraIG, Weights and Measures Representatice, Dayton Scale Division, Troy, Ohio.

Burss H. Dreese, General Manager, Penn Avenue at Simpson Street, Troy, Ohio.

ERnest A. Reussexzehr, Chief Scale Engineer, Daston Scale Division, 448 Huffman Arenue, Dayton 3, Ohio.

e Scale Co.:

Edwin W. Counts, Sales Engineer, P. O. Box 611, Radford, Va.

Robert A. PARHAM, Branch Ianager, 309 East Saratoga Street, Baltimore 2, IId.

Richard F. Straw, Vice President, Rutland, Vt.

man Mfg. Co.: Roвert E. DorMan, General Manager, Automotive Division O. Box 69, Delphos, Ohio.

son Scale Co. : Allen Y. Johnsox, President. 84 Walnut Street, Newark, N. J. id-Tight Paper Container Association: ArTHUr W. Howe, Jr., 1532 Lincolnberty Building, Philadelphia $\tau$, Pa.

e. Joe, Corp.: Norman H. Thomas, Sales Manager, 601 West Twenty-sixth reet, New York, N. Y.

vel Rack Mfg. Co., Inc.: Charles M. McCarthy, President, 24 North First reet, Minneapolis 1, Minn.

atyre, John J., Sons :

F. L. MICINTYRe, 514-16 Knorr Street, Philadelphia 11, Pa.

John La wrence McIntyre, 514-16 Knorr Street, Philadelphia 11, Pa.

suregraph Co.: GeNe A. Powell, Regional Manager, 2306 Poplar Grove reet, Baltimore $16, \mathrm{IId}$.

onnier Bros. Co.: Alfred C. Woodruff, Sales Representative, 324 spring alley Road, Springfield, Delaware County, Pa.

dy, Edward G., \& Son, Inc.: Edward G. Moopy, Nashua, N. H.

onal Scale Service: Mrs. E. W. Counts, Office Manager, Box 611, Radford, 1).

onal Store Specialty Co. :

John H. Landvater, Engineer, Bareville, Pa.

Wallace E. Sheaffer, President, Bareville, Pa.

Tham Mfg. Co.: Carl F. Spaxg, Partner-General Sales Manager, Dirision arnes Scale Co., 591 Hillside Arenue, Needham Heights, Mass.

tune Meter Co.:

CharLes S. HAzArd, Director of Research, 192 Jackson Arenue, Long Island City, N. Y.

H. A. Lentz, Jr., 14 Bell's Mill Road, Philadelphia 18, Pa.

WALter H. SIEger, Assistant to General Sales Manager, 50 West Fiftieth Street, New York 20, N. Y.

Emartt F. Wemiann, Engineer, Engineering Department, 192 Jackson Avenue, Long Island City, N. Y.

npic Instrument Laboratories: CARLyle A. Creceluus, Manager, Box 62, ve, Wash.

nns-Illinois Glass Co., J. D. LAInd, Chief Supervisor, Quality and Specificaons, Toledo, Ohio.

-Tee Equipment Co. :

Firmax NiedwlaxdT, Superintendent, Spencerville, Ind.

Tom Partee, Vice President-Sales, Spencerville, Ind.

rless Weighing \& Vending Machine Corporation:

PaUl IV. Barras, Philadelphia District Manager, 218 Huntley Road, Upper Darby, Pa.

James J. Crosby, Vice President, 29-28 Forty-first Avenue, Long Island Citr, N. Y.

n Scale Mfg. Co., Inc.: SYdNey Black, President, 150 West Berks Street, hiladelphia 22, Pa.

sublic Steel Corp.: K. A. BLox, Corporation Weighing Supervisor, 1106 Reublic Building, 25 Prospect Arenue, Clereland 1, Ohio. 
liockwell Manufacturing Co.:

Edward R. Eyler, Sales Engineer, 12 Mayflower Court, Baltimore, Md. Chas. B. Johnson, Chief Engineer, 400 North Lexington Avenue, Pittsb $8, \mathrm{~Pa}$.

Robert A. Johnson, Assistant Sales Manager, L. P. Gas Products, 400 I Lexington Avenue, Pittsburgh 8, Pa.

James H. Judge, Sales Manager, Gasoline, Oil \& Industrial Meters, $400 \mathrm{~N}$ Lexington Arenue, Pittsburgh S, Pa.

R. F. McConmick, Chief Engineer, Gasoline and Oil Division, $400 \mathrm{~N}$ Lexington Avenue, Pittsburgh 8, Pa.

Chas. H. Oвrock, Sales Engineer, 7701 Empire State Building, New I N. Y.

Sanitary Scale Co.: J. V. FArwell, III, President, 664 North Michigan Avf Chicago, Ill.

Saybolt, E. W., \& Co. :

Justrn E. Keith, Manager Pacific Division, 529 Avalon Boulevard, Wiln ton, Calif.

Hammond C. Spindell, 265 Bayway, Elizabeth, N. J.

Sealright Co., Inc.: Eart Foster, Chief Chemist, Fulton, N. Y.

Seraphin Test Measure Co.: T. A. Seraphin, General Manager, $1314 \mathrm{~N}$

Seventh Street, Philadelphia, Pa.

Sharpsville Steel Fabricators, Inc.: Charles D. Fagan, President, Sharps $\mathrm{Pa}$.

Smith, A. O., Corporation :

Thomas C. Ficken, South East District Manager, Meter Division, $153 \mathrm{Na}$ Street, Atlanta, Ga.

Wilson M. Milligan, Sales Manager, Eastern Area, Meter Division, I Box 500, Succasunna, N. J.

W. G. Moser, General Manager, Meter Division, 5715 Smithway Street, Angeles 22, Calif.

Stimpson Computing Scale Co.:

Frank M. Doyne, General Distributor, 468 Weaver Street, Larchmont,

JoHn J. WAAgE, President, 829 Logan Street, Louisville, Ky.

Streeter-Amet Co.: Verne C. Kennedy, Jr., Supervisor of Engineering, Ravenswood Avenue, Chicago 13, Ill.

Sutherland Paper Co.: L. J. Moone, Assistant Manager, Paraffined Ca Division, 243 East Paterson Street, Kalamazoo, Mich.

Thatcher Glass Manufacturing Co., Inc.: James Arrandale, Director, Que Control \& Service Department, Elmira, N. Y.

Tokheim Oil Tank \& Pump Co.: William E. Louthan, Service Manager, ]

Wayne, Indiana.

Toledo Scale Co. :

Stanley Q. Bennett, Manager of Service and Weights and Measures I sion, Toledo 1, Ohio.

D. J. Boudnot, Industrial Sales Manager, Toledo 1, Ohio.

R. Bradley, Toledo 1, Ohio.

Merrell E. Holmes, Assistant General Sales Manager, Toledo 1, Ohio. Thurlo Johnson, Assistant National Service Manager, Toledo 1, Ohio.

Albert E. Jones, Dirisional Manager, 223 West Exchange Street, Akro Ohio.

Byron D. Miller, Manager, Steel Industry Relations, 1156 Hanna Build Cleveland 15, Ohio.

E. C. Smith, Industrial Division, 213-215 East 27th Street, New York N. Y.

Triner Scale \& Mfg. Co. : Frank A. Lang, Representative, 2714 West Twenty-1 Street, Chicago, Illinois.

Troemner, Henry :

Edward J. Furey, General Manager, 911 Arch Street, Philadelphia 7, P:

Charles F. Rosica, Sales Manager, 911 Arch Street, Philadelphia 7, Pa.

U. S. Slicing Machine Co., Inc. : Matthew D. Ribble, Special Representat

Standard Computing Scale Division, La Porte, Ind.

Veeder-Root, Inc.:

J. J. Brannick, Sales Manager, Computer Division, 915 Van Buren Str N. E., Auburn, Ind.

Austin E. McKeever, Sales Manager, Master Meter Duplicator Divis Hartford 2, Conn.

David J. Post, Vice President, Hartford 2, Conn.

Washington Scale \& Equipment Co.: Aaros Yochelson, Partner, 1107 I Jersey Avenue, N. W., Washington, D. C. 
Pump Co. :

F. Bateman, Chief Engineer, Salisbury, Md.

V. O. Howland, Engineer, Salisbury, Md.

ouis Soltanoff, Project Engineer, 302 South Boulerard, Salisbury, Md.

Corporation: C. H. Bentley, President, Webb City, Mo.

low Gov't Std. Scale Works, Inc. : Carl E. Ehrenhardt, Secretary, 25th and wthorne Avenue, Terre Haute, Ind.

1. John, Co. :

ouIs G. Close, Manager, Baltimore District, Bennett Pump Division, 2127 North Charles Street, Baltimore 18, Md.

Tilliam M. Hoxie, Service Manager, Bennett Pump Division, Broadway and Lethan, Muskegen, Mich.

\section{STS REPRESENTING ASSOCIATIONS, BUSINESS, AND INDUSTRY, AND RAILROADS}

cican Paper Goods Co.: Lloyd W. VibBerts, Production Superintendent, nsington, Conn.

rican Petroleum Institute: B. H. LoRd, JR., Assistant to Director, Division Transportation, $1625 \mathrm{~K}$ Street, N. W., Washington, D. C.

ciated Tobacco Manufacturers: Edward F. Ragland, Executive Secretary, ite 104-105 Willard Hotel, Washington 4, D. C.

ciation of American Soap \& Glycerine Producers, Inc. : Rox W. Peet, Maner, 295 Madison Avenue, New York 17, N. Y.

fas \& Durbrow, Inc.: Robert C. Read, General Manager, 165 John Street, w York 38, N. Y.

ntic Refining Co.: EmIL P. GoHn, 260 South Broad Street, Philadephia, Pa. more \& Ohio Railroad Co.: E. Kent Lawrence, General Scale Inspector, lintenance of Way Department, Baltimore 1, Md.

fdian Peat Producers Association: E. E. Carncross, Box 699, New Westnster, B. C., Canada.

mercial Textile Mfg. Co.: ArNold S. White, General Manager, 49 K Street. W., Washington, D. C.

y Industries Supply Association, Inc.: Robert J. HAxger, 1108 Sixteenth reet, N. W., Washington $6, \mathrm{D}$. C.

ia Cup Co.: Arthur J. Nolan, Vice President, Easton, Pa. Standard Oil Co. :

NeLson Friz, Construction and Maintenance Assistant, 15 West Fifty-first Street, New York 19, N. Y.

L. L. Kennedy, Superintendent, Construction and Maintenance, 500 North Broad Street, Elizabeth 3, N. J.

line Pump Manufacturers Association: G. DeNny Moone, Managing Director, aybar Building, 420 Lexington Avenue, New York 17, N. Y.

ral Ice Cream Corporation:

A. H. BAYER, Vice President and Director of Research and Production, 101 Nott Terrace at Eastern Avenue, Schenectady, N. Y.

A. C. Fisher, Vice President and Treasurer, 101 Nott Terrace at Eastern Arenue, Schenectady 1, N. Y.

G. Emerson Sartain, Producer Relations, Bryant \& Chapman Dairy, Division of General Ice Cream Corporation, 255 Homestead Avenue, Hartford. Conn.

S Container Manufacturers Institute, Inc.: C. E. Wagner, Development Igineer, 8 West Fortieth Street, New York City 18, N. Y.

cester Fisheries Association : L. J. HART, Secretary, 120 Main Street, Glouces Mass.

Atlantic \& Pacific Tea Co.: R. G. Carpenter, National Meat Department, 1 West Wacker Drive, Chicago 6, Ill.

Oil Corporation :

E. C. DICKEY, Atlanta Sales Division, Gulf Building, Atlanta, Ga.

IV. K. McCor, General Superintendent Marketing Equipment, Gulf Building Pittsburgh, Pa.

strial Research Syndicate: C. A. Lindsay, Director, 1305 Euclid Street, N. W.. ashington, D. C.

rnational Association of Ice Cream Manufacturers:

Rosert H. North, Executive Assistant, 1105 Barr Building, Washington, D. C. Dovalm H. Williams, Assistant to Executive Secretary, 1105 Barr Building, Washington, D. C. 
Lily-Tulip Cup Co.: Leoxard J. Ixglis, Assistant to Vice President, 122 Forts-second Street, New York, N. Y.

Lorillard, P., Co.: Herbert R. O'Conor, Jr., 10 Light Street, Baltimore, MId Marradel Ice Cream Co.: JoHx C. Krusen, Manager, 4001 Seven Mile ] Baltimore S, Md.

MLaryland-Virginia Milk Producers Association: Cecis F. Cole, Field $\mathrm{P}$ sentative, 1756 K Street, N. W., Washington, D. C.

Michigan Peat, Inc:

Dox Express, Vice President, Capac, Mich.

Mrs. E. P. Poppex, President, 267 Fifth Arenue, New York, N. Y.

Nillers National Federation:

Herman Fakler, Vice President, National Press Building, Washington,

John J. McCracken, Assistant to Vice President, National Press Buil Washington, D. C.

Mock Seed Co. : Fred G. Mock, 1218 Smallman Street, Pittsburgh, Pa.

National Association of Dairy Equipment Manufacturers: JoHN MaRsI Executive Secretary, 927 Fifteenth Street, N. W., Washington, D. C.

National Association of Scale Manufacturers: ARTHur SANDERs, No. 1 Th Circle. Washington, D. C.

National Fisheries Institute, Inc.: Charles E. Jacksox, General Man 1614 Twentieth Street, N. W., Washington 9, D. C.

Paper Cup and Container Institute, Inc:

Dale H. Eckerman, Executive Director, 1790 Broadway, Room 702, York $19, \mathrm{~N}$. Y.

Robert W. Foster, Assistant Executive Director, 1790 Broadwar, New N. Y.

Pennsylvania Railroad :

Byrox R. Nelson, Eastern Region, Pennsylvania Station, 30th St Philadelphia, Pa.

Millard A. Pinney, Engineer of Tests, Test Department, Altoona, Pa.

Philadelphia Seed Co.: J. B. Hertzfeld, Arch and Front Streets, Philadel Pa.

Pillsbury Mills, Inc.

Otis W. Galloway, Claim Agent, 608 Pillsbury Building, Minneapolis, 1

Bradshaw Mintener, Vice President and General Counsel, 600 Pills Building, Minneapolis, Minn.

Premier Peat Moss Corp.: Malcolar T. Graham, Vice President, 535 I Arenue, New York, N. Y.

Safeway Stores, Inc. :

Annold J. Anderson, Retail Operations Manager, 1845 Fourth Street, N Washington, D. C.

Edgar Balshaw, Dirision Manager, 1845 Fourth Street, N. E., IVashin D. C.

Luke Beale, Employee Relations Manager, 1845 Fourth Street, N. Washington, D. C.

Frank J. Sheehan, Manager, Public Relations, Dexter Services, 726 Jac: Place, N. W., Washington $6, \mathrm{D}$. C.

Joseph W. Upton, Price Maker, 1845 Fourth Street, N. E., Washington, I

SAybolt, J. W., Business Counsellor on Weights and Measures Laws, Carlyle Arenue, Surfside, Niami Beach, Fla.

Scale Journal Publishing Co.: Mrs. Edith J. SAYbolt, 1703 East Eighty-fo Street, Chicago 17, Ill.

Shell Oil Co. :

B. F. Carson, Division Engineer, Baltimore, Md.

Joseph Y. HAzeN, Dirision Engineer, 37-06 Eighty-second Street, Jac] Heights, N. Y .

LEoxard E. Noud, Field Engineer, New York Dirision, 37-08 Eighty-ser Street, Jackson Heights, N. Y.

Sinclair Refining Co.: Kenneth W. BIRKrn, Manager, Automotive Departn 600 Fifth Arenue, New York, N. Y.

Socony-Tacuum Oil Co., Inc.: E. L. Hofruan, 26 Broadway, New York 4, I Southern Railway System:

Bex F. Gilbert, Chief Scale Inspector, Room 817 Southern Railway Builc Washington, D. C.

J. N. Tond, Superintendent of Scales and Work Equipment, Office of C Engineer, P. O. Box 1808, Washington 13, D. C. 
thern Weighing and Inspection Bureau: Alfred J. Reynolds, General Superisor in Charge of Weighing and Weights, 511-101 Marietta Street Building, tlanta, Ga.

zas Co.: H. W. Holland, Manager of Operations, 135 East Forty-second Street, iew York, N. Y.

read Institute, Inc. :

John BeLr, Chairman, Legislation Committee, 11 West Forty-second Street, New York 18, N. Y.

J. W. Shaver, Director, 11 West Forty-second Street, New York 18, N. Y.

David Snyder, Executive Director, 11 West Forty-second Street, New York 18, N. Y.

king Corporation :

Elliot Balestier, Jr., Assistant to President, 711 Bowen Building, 815 Fifteenth Street, N. W., Washington 5, D. C.

Wirlaam M. SaWers, 711 Bowen Building, 815 Fifteenth Street, N. W., Washington $5, \mathrm{D}$. C.

stern Weighing and Inspection Bureau: E. M. CURL, Room 460 Union Station, 17 IVest Adams Street, Chicago 6, Ill.

\section{OTHER GUESTS}

S. Arbuckle, Dairy Department, University of Maryland, College Park, Md. ARLES BAUER, 328 West Ridge Road, Gary, Indiana.

K S. Conrad, Dairy Department, University of Maryland, College Park, Md. 、. F. Joseph Donohue, President, Board of Commissioners, District of Jolumbia, District Building, Washington, D. C.

JRGE A. Howe, 112 Fourth Street, S. E., Washington, D. C.

rold A. Newlander, University of Maryland, College Park, Md.

EPH W. Nisonger, Instructor, Dairy Department, University of Maryland, ollege Park, Md.

Col. Alex Pisciotta, 3348 Gunston Road, Alexandria, Va.

RRY G. SMITH, Wadsworth, Ohio.

W. SMith, 700 Elm Street, Chevy Chase, Md. 



\section{NATIONAL CONFERENCE ON WEIGHTS AND}

\section{MEASURES REPORTS}

\begin{tabular}{|c|c|c||r|r|r|}
\hline \begin{tabular}{rl|l|} 
Misc. \\
Pub.
\end{tabular} & Year & Price & $\begin{array}{r}\text { Misc. } \\
\text { Pub. }\end{array}$ & Year & Price \\
\cline { 1 - 3 } 4 & 1905 & OP & 74 & 1926 & OP \\
5 & 1906 & OP & 80 & 1927 & OP \\
6 & 1907 & OP & 87 & 1928 & OP \\
7 & 1908 & OP & 101 & 1929 & OP \\
8 & 1910 & OP & 116 & 1930 & OP \\
9 & 1911 & OP & 129 & 1931 & OP \\
10 & 1912 & OP & 156 & 1935 & OP \\
11 & 1913 & OP & 157 & 1936 & OP \\
12 & 1914 & OP & 159 & 1937 & OP \\
13 & 1915 & OP & 161 & 1938 & OP \\
14 & 1916 & OP & 164 & 1939 & OP \\
41 & 1919 & OP & 167 & 1940 & $55 \phi$ \\
43 & 1920 & OP & 170 & 1941 & $35 \phi$ \\
48 & 1921 & OP & 186 & 1946 & $40 \phi$ \\
51 & 1922 & OP & 189 & 1947 & $40 \phi$ \\
55 & 1923 & OP & 195 & 1949 & $35 \phi$ \\
59 & 1924 & OP & 199 & 1950 & $50 \phi$ \\
70 & 1925 & OP & 202 & 1951 & $50 \phi$ \\
\hline
\end{tabular}

Where prices are given, the publication may be purchased from e Superintendent of Documents, Government Printing Office, Washgton 25, D. C. Remittances should be made by coupons (obtainable $\mathrm{m}$ the Superintendent of Documents in sets of 20 for $\$ 1$ and good til used), by money order, or check payable to the Superintendent Documents, Government Printing Office, or by cash; and the remitace should accompany the order. Orders should be sent to the perintendent of Documents, and not to the National Bureau of andards. The Publications marked $O P$ are out of print, but may be ailable for consultation in public libraries in large cities or in the raries of leading universities and colleges. 
